\title{
De Gelderse arbeidsmarkt : 2002-2006
}

Citation for published version (APA):

Cörvers, F., Diephuis, B. J., van Eijs, P. W. L. J., Golsteyn, B. H. H., \& Hensen, M. M. (2003). De Gelderse arbeidsmarkt : 2002-2006. ROA. ROA Reports No. 004

https://doi.org/10.26481/umarep.2003004

Document status and date:

Published: 01/01/2003

DOI:

10.26481/umarep.2003004

Document Version:

Publisher's PDF, also known as Version of record

\section{Please check the document version of this publication:}

- A submitted manuscript is the version of the article upon submission and before peer-review. There can be important differences between the submitted version and the official published version of record.

People interested in the research are advised to contact the author for the final version of the publication, or visit the DOI to the publisher's website.

- The final author version and the galley proof are versions of the publication after peer review.

- The final published version features the final layout of the paper including the volume, issue and page numbers.

Link to publication

\footnotetext{
General rights rights.

- You may freely distribute the URL identifying the publication in the public portal. please follow below link for the End User Agreement:

www.umlib.nl/taverne-license

Take down policy

If you believe that this document breaches copyright please contact us at:

repository@maastrichtuniversity.nl

providing details and we will investigate your claim.
}

Copyright and moral rights for the publications made accessible in the public portal are retained by the authors and/or other copyright owners and it is a condition of accessing publications that users recognise and abide by the legal requirements associated with these

- Users may download and print one copy of any publication from the public portal for the purpose of private study or research.

- You may not further distribute the material or use it for any profit-making activity or commercial gain

If the publication is distributed under the terms of Article $25 \mathrm{fa}$ of the Dutch Copyright Act, indicated by the "Taverne" license above, 


\section{De Gelderse arbeidsmarkt}

2001-2006

ROA-R-2003/4

F. Cörvers

B.J. Diephuis

P. van Eijs

B. Golsteyn

M. Hensen

\section{Researchcentrum voor Onderwijs en Arbeidsmarkt}

Faculteit der Economische Wetenschappen en Bedrijfskunde Universiteit Maastricht

Maastricht, februari 2003 
Niets uit deze uitgave mag worden verveelvoudigd en/of openbaar gemaakt door middel van druk, fotokopie, microfilm, of op welke wijze ook, zonder voorafgaande schriftelijke toestemming van de directeur van het Researchcentrum voor Onderwijs en Arbeidsmarkt. In geval van overname van het datamateriaal moet telkens als bron worden vermeld: "Researchcentrum voor Onderwijs en Arbeidsmarkt" of "ROA". Van publicaties waarin gebruik wordt gemaakt van gegevens uit dit rapport ontvangen wij gaarne een exemplaar.

Hoewel de grootst mogelijke zorg is besteed aan de inhoud van dit rapport, kan het ROA in generlei opzicht verantwoordelijkheid op zich nemen voor eventuele onvolledigheden of onjuistheden.

ISBN 90-5321-361-9

Sec03.016.doc 


\section{Inhoudsopgave}

Bladzijde

Voorwoord

Ten geleide

1 De Gelderse arbeidsmarkt in vogelvlucht 1

1.1 Inleiding 2

1.2 Groeitrends in Gelderland en Nederland 2

1.3 Kenmerken en ontwikkeling van de werkzame beroepsbevolking in Gelderland

1.4 Arbeidsmarktdiscrepanties voor schoolverlaters van het MBO 6

1.5 De verwachte arbeidsmarktontwikkelingen in Gelderland op
hoofdlijnen

1.6 De verwachte arbeidsmarktsituatie naar opleiding en beroep op de
korte termijn

1.7 De verwachte arbeidsmarktsituatie naar opleiding en beroep op de middellange termijn

2 Het beroepsonderwijs in Gelderland 15

$\begin{array}{ll}2.1 \text { Inleiding } & 16\end{array}$

2.2 Het aantal gediplomeerden in Gelderland 16

2.3 Het aantal leerlingen in Gelderland $\quad 18$

2.4 De arbeidsmarktpositie van MBO-schoolverlaters 20

3 De Gelderse arbeidsmarkt op de korte en de middellange termijn 29

$\begin{array}{ll}3.1 \text { Inleiding } & 30\end{array}$

$\begin{array}{ll}3.2 \text { Uitbreidingsvraag } & 30\end{array}$

$\begin{array}{lll}3.3 & \text { Vervangingsvraag } & 39\end{array}$

3.4 Baanopeningen 45

3.5 Aanbod van schoolverlaters $\quad 52$

4 Knelpunten en perspectieven op de Gelderse arbeidsmarkt 57

4.1 Inleiding 58

4.2 De arbeidsmarktperspectieven voor schoolverlaters 59

4.3 Knelpunten in de personeelsvoorziening voor werkgevers 63

$\begin{array}{ll}4.4 & \text { Uitwijkmogelijkheden voor schoolverlaters }\end{array}$

$\begin{array}{lll}4.5 & \text { Substitutiemogelijkheden voor werkgevers } & 71\end{array}$

5 Pendel tussen Gelderland en omliggende gebieden $\quad 75$

$\begin{array}{ll}5.1 & 76\end{array}$

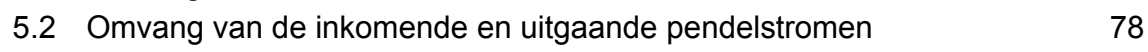

$\begin{array}{lll}5.3 & \text { Achtergrondkenmerken van de pendelaars } & 79\end{array}$

5.4 Pendelstromen als oplossing voor regionale
arbeidsmarktdiscrepanties

5.5 De buitenlandse arbeidsmarkt 89 
6 Het onbenutte arbeidspotentieel in Gelderland 93

$\begin{array}{ll}6.1 \text { Inleiding } & 93\end{array}$

6.2 Achtergronden en kenmerken 94

6.3 Veranderingen in het onbenutte arbeidspotentieel 98

$\begin{array}{ll}\text { 6.4 Inzetbaarheid van het onbenutte arbeidspotentieel } & 101\end{array}$

$\begin{array}{ll}\text { Verklarende woordenlijst } & 103\end{array}$ 


\section{Voorwoord}

Met de totstandkoming van de Regionale Platvormen Arbeidsmarktbeleid (RPA's) is er een verantwoordelijkheid ontstaan voor gemeenten en sociale partners voor het arbeidsmarktbeleid. Met de totstandkoming van 7 Regionale Platvormen Arbeidsmarktbeleid in Gelderland constateren wij dat het ook mogelijk is om het overleg over de arbeidsmarkt aan te laten sluiten op de sociaal-economische overlegstructuur en het onderwijs in de regio.

Provincie Gelderland vindt dit een uitstekende ontwikkeling en heeft gemeend er goed aan te doen dit proces te ondersteunen met de realisatie van deze studie naar de ontwikkelingen op de arbeidsmarkt tot 2006 en specifiek hierin de ontwikkelingen naar opleiding en beroep.

De partijen in de RPA's staan voor de uitdaging om enerzijds werkzoekenden aan een baan te helpen en anderzijds de knelpunten op de vacaturemarkt op te lossen.

De arbeidsmarkt is door velen te lange tijd gezien als een werkloosheidsmarkt. De aansluiting tussen vraag- en aanbod is één van de meest hardnekkige knelpunten op de arbeidsmarkt. Kwalitatieve discrepanties zorgen er voor dat 'onvervulde vacatures' en 'werkloosheid' gelijktijdig voorkomen.

De arbeidsmarkt is breder. Het betreft het gehele voorzieningenniveau om economisch en maatschappelijk te voorzien in voldoende en voldoende gekwalificeerde arbeidskrachten alsook het streven naar werk voor iedereen. Voor een belangrijk deel gaat dat als het ware 'automatisch'.

Een goede afstemming tussen de instroom in het onderwijs en de vraag naar bepaalde beroepen in de toekomst kan dit 'automatisme' nog verder versterken. Afstemming vereist echter inzicht in de toekomstige vraag- en aanbodverhoudingen naar opleidingsniveau en beroep. Bij alle voortreffelijke gegevens die reeds voor handen zijn, was deze verfijning op regionaal niveau tot op heden nog een onvervulde wens. Met deze studie is hier een basis voor gelegd.

In de komende periode zullen wij op een andere wijze dan tot voor kort met de arbeidsmarktproblematiek geconfronteerd worden omdat het anno 2003 iets minder gaat met de economische ontwikkeling maar ook omdat we in de komende decennia te maken zullen krijgen met 'ontgroening en vergrijzing'.

Indien wij het ons nu veroorloven om nu de arbeidsmarktgebeurtenissen niet goed aanpakken zullen we daar in de zeer nabije toekomst de wrange vruchten van plukken.

Wij denken dat met de realisatie van RAMING een instrument beschikbaar is gekomen waarmee een bijdrage kan worden geleverd aan de oplossing van de aansluitingsproblematiek op de arbeidsmarkt. Het woord is nu aan het CWI's, het onderwijs en de Gelderse sociale partners om de onderzoeksresultaten te vertalen in concrete opleidingsprogramma's, bemiddelingsacties en voorlichtingscampagnes.

In de overtuiging dat hiermee de basis is gelegd voor een succesvol arbeidsmarktbeleid zijn wij bereid ook in de toekomst hierin te investeren. Tijdens de 
uitvoering van het project is gebleken dat de gegevens over de regionale in- en uitstroom van het onderwijs ernstige tekortkomingen vertoont. Onze pogingen hierin verbetering te brengen zijn tot op heden nog niet gelukt omdat zij onvoldoende weerklank hebben gevonden bij een groot deel van de Gelderse onderwijsinstellingen. Wij geven de moed echter nog niet op. Wij zullen de komende periode gebruiken voor een hernieuwde poging om tot een sluitende en uniforme Gelderse schoolverlatersregistratie te komen. Vanuit deze plaats doe ik een dringend beroep op alle Gelderse onderwijsinstellingen hieraan hun medewerking te verlenen. $U$ hoort nog van ons.

Allen succes toe wensend bij de totstandkoming van een effectief regionaal arbeidsmarkt beleid.

Henk Aalderink

Gedeputeerde Economische Zaken van Provincie Gelderland 


\section{Ten geleide}

Het thans voor $\mathrm{u}$ liggende rapport De Gelderse arbeidsmarkt 2001-2006 is op initiatief van de Provincie Gelderland tot stand gekomen in het kader van het project Regionale ArbeidsMarkt INformatie Gelderland (RAMING). Het doel van RAMING is het ontwikkelen en actualiseren van een informatiesysteem dat een breed overzicht geeft van de huidige arbeidsmarktsituatie en de toekomstige arbeidsmarktontwikkelingen in de provincie Gelderland en de zeven onderscheiden RPA-rayons (Regionale Platvorms Arbeidsmarkt). Uit dit overzicht komen de huidige en toekomstige discrepanties naar beroep en opleiding naar voren. Op basis van het informatiesysteem van RAMING kan door de provincie Gelderland en de verschillende arbeidsmarktparticipanten in de provincie beleid geformuleerd en uitgevoerd worden. Bovendien kan de informatie gebruikt worden in het kader van de studie- en beroepskeuzevoorlichting, bijvoorbeeld voor jongeren die hun opleidingskeuze moeten bepalen.

ROA en ETIL voeren reeds sinds 1997 gezamenlijk de arbeidsmarktmonitor Regionale Arbeidsmarkt Informatie Limburg (RAIL) uit, dat wat betreft de onderzoeksopzet als voorbeeld dient voor RAMING. Dit betekent enerzijds dat er een samenwerkingsrelatie gegroeid is tussen ROA en ETIL waarbij gegevens- en kennisuitwisseling plaatsvindt; anderzijds zijn de resultaten regelmatig geëvalueerd. Dit alles heeft in de loop der jaren geresulteerd in een verdere ontwikkeling van de arbeidsmarktmonitor. Consistentie van de onderzoeksgegevens binnen de provincie, maar ook met landelijk beschikbare bronnen, staat daarbij hoog in het vaandel. Dit wordt mede bewerkstelligd doordat RAMING een regionale verbijzondering is van het door het ROA uitgevoerde landelijke Project Onderwijs-Arbeidsmarkt (POA). In het algemeen geldt derhalve dat de prognosemethodiek is afgeleid van de landelijk gebruikte methodiek binnen (POA). ${ }^{1}$ Op basis van dit project wordt reeds vanaf 1989 tweejaarlijks het rapport De arbeidsmarkt naar opleiding en beroep tot .... uitgebracht met onder meer prognoses naar opleiding en beroep voor de middellange termijn. Het vergelijkbare onderzoekskader van POA en RAMING maakt het mogelijk de regionale arbeidsmarktontwikkelingen relatief eenvoudig af te zetten tegen de landelijke ontwikkelingen.

Door zowel de huidige situatie als de toekomstige ontwikkelingen te beschrijven, heeft RAMING hiermee een signaleringsfunctie voor diverse gebruiksdoelen. Hierbij kan gedacht worden aan het personeels- en rekruteringsbeleid van werkgevers, het initiëren en bijsturen van bij- en omscholingsprogramma's voor niet-werkende werkzoekenden, de arbeidsbemiddeling en het arbeidsmarkt- en onderwijsbeleid. Tegelijkertijd met dit rapport verschijnt ook de bijbehorende Statistische Bijlage.

1. Zie 'Doel en opzet van de arbeidsmarktprognoses' en de begrippenlijst in het ROA-rapport, De arbeidsmarkt naar opleiding en beroep tot 2006, ROA-R-2001/8, Maastricht. Zie verder ook F. Cörvers c.s. (2002), Methodiek arbeidsmarktprognoses en -indicatoren 2001-2006, ROA-W-2002/4, Maastricht; F. Cörvers, A. de Grip and H. Heijke, Beyond manpower planning: a labour market model for the Netherlands and its forecasts to 2006, in: M. Neugart and K. Schömann (eds., 2002), Forecasting Labour Markets in OECD countries, Edward Elgar, pp. 185-223. 
Hierin wordt een systematisch kwantitatief overzicht gegeven van de actuele arbeidsmarktgegevens en de verwachte ontwikkelingen die ten grondslag liggen aan dit hoofdrapport. De actuele arbeidsmarktinformatie en de prognoses over werkenden en schoolverlaters zijn in de Statistische Bijlage veel verder uitgesplitst dan in het voorliggende hoofdrapport. Daarnaast bevat de Statistische Bijlage arbeidsmarktinformatie over werkzoekenden en vacatures van CWI Oost-Nederland.

De arbeidsmarktgegevens met betrekking tot de werkzame en niet-werkzame bevolking zijn afkomstig uit de Enquête Beroepsbevolking (EBB) van het Centraal Bureau voor de Statistiek (CBS). Voorts is er informatie gebruikt van de Gelderse ROC's en AOC's in het kader van de Bekostigingstellingen van de Centrale Financiën Instellingen (Cfi/Ministerie van OCenW) en de Landbouwtellingen ${ }^{2}$ van STOAS (i.o.v. Ministerie van LNV). De informatie over de actuele arbeidsmarktpositie van MBO-schoolverlaters en is gebaseerd op gegevens uit het Schoolverlaters Informatie Systeem (SIS) van het ROA. Om de kwaliteit van deze gegevens voor Gelderland verder te vergroten en verdergaande uitsplitsingen naar opleidingsrichting te kunnen maken is een verhoging van de deelname van Gelderse ROC's en AOC's aan het Schoolverlaters Informatie Systeem noodzakelijk. De prognoses binnen RAMING zijn (deels) gebaseerd op de uitkomsten van het landelijke model waarvan de uitkomsten door het ROA zijn gepresenteerd in De arbeidsmarkt naar opleiding en beroep tot 2006 (ROA-R-2001/8). Het Bureau Economisch Onderzoek (BEO) van de Provincie Gelderland heeft de prognoses voor de werkgelegenheidsgroei per bedrijfssector aan het ROA geleverd. Bij het samenstellen van deze prognoses door BEO was de consistentie met de landelijke sectorprognoses een belangrijke randvoorwaarde.

Het rapport bestaat uit zes hoofdstukken. De eerste drie hoofdstukken geven een overzicht van de huidige en toekomstige vraag- en aanbodontwikkelingen op de Gelderse arbeidsmarkt. In hoofdstuk 1 wordt een globaal overzicht gegeven van de belangrijkste arbeidsmarktontwikkelingen verbijzonderd naar bedrijfssector, beroepsklasse en opleidingssector. In hoofdstuk 2 wordt een overzicht gepresenteerd van de actuele aantallen leerlingen en gediplomeerden in het voorbereidend en middelbaar beroepsonderwijs in Gelderland op basis van data die door de Gelderse ROC's zijn verstrekt aan het Ministerie van OCenW en het Ministerie van LNV (Bekostigingstellingen van het CFI respectievelijk STOAS). Tevens wordt in het hoofdstuk aangegeven wat de mate van open en verborgen discrepanties op de arbeidsmarkt is voor schoolverlaters van het MBO. Deze bespreking van de arbeidsmarktpositie van MBO-schoolverlaters gebeurt op basis van het eerder genoemde Schoolverlaters Informatie Systeem (SIS) van het ROA. Hoofdstuk 3 gaat nader in op de te verwachten ontwikkelingen aan de vraag- en aanbodzijde van de Gelderse arbeidsmarkt op de korte en middellange termijn, waarbij tevens een vergelijking met de verwachte vraag- en aanbodontwikkelingen in Nederland wordt gemaakt.

2. Opgemerkt dient te worden dat de gegevens van de gediplomeerden in de landbouwopleidingen van het VMBO en het MBO in het kalenderjaar 2000 alleen betrekking hebben op de gediplomeerden die niet in het onderwijs doorstromen. 
Het confronteren van vraag en aanbod resulteert vervolgens in hoofdstuk 4 in een overzicht van de in 2003 en 2006 te verwachten discrepanties naar opleiding en beroep. Tevens bevat het hoofdstuk een analyse van de mogelijkheden voor schoolverlaters met een bepaalde opleidingsachtergrond uit te wijken naar verschillende beroepen op de arbeidsmarkt (uitwijkmogelijkheden), en de mogelijkheden voor werkgevers om schoolverlaters met een verschillende opleidingsachtergrond in te zetten in bepaalde beroepen (substitutiemogelijkheden).

In hoofdstuk 5 wordt een analyse van de inkomende en uitgaande pendel van Gelderland gemaakt. Hierbij wordt de omvang van de pendel met andere provincies en het buitenland weergegeven, worden de achtergrondkenmerken van pendelaars bekeken en wordt een indruk gegeven van de mogelijkheden om door beïnvloeding van de pendel de krapte op de Gelderse arbeidsmarkt op de middellange termijn te verlichten.

Tot slot wordt in hoofdstuk 6 een beeld van de achtergrondkenmerken en ontwikkeling van het onbenutte arbeidspotentieel in Gelderland gegeven. In het hoofdstuk wordt nagegaan in welke mate het onbenutte arbeidspotentieel van werklozen en niet-participerenden de schaarste op de arbeidsmarkt kan verlichten.

De projectleiding van RAMING is bij het ROA in handen geweest van F. Cörvers. Aan het hoofdrapport en de bijbehorende Statistische Bijlage is bij het ROA meegewerkt door B.J. Diephuis, S. Dijksman, P. van Eijs, B. Golsteyn en M. Hensen.

Onze dank gaat uit naar de leden van de begeleidingscommissie van RAMING. De voorzitter van de begeleidingscommissie was dhr. M. Walsweer van Bureau Economisch Onderzoek (BEO) van de provincie Gelderland. Hij werd bijgestaan door dhr. C. Bijkerk van de Provincie Gelderland. Voorts hebben de volgende personen zitting gehad in de begeleidingscommissie: namens de Regionale Platvormen Arbeidsmarktbeleid (RPA's) dhr. W. Krooshof, dhr. H. Verschoor, dhr. W. Spinhoven, dhr. D. Koetsier, dhr. J.Theunissen, dhr. T. Jansen en dhr. I. Kakes, namens de Sociale Partners Gelderland (SOPAG) mevr. K. Schats en mevr. K. van Helden, en namens CWI Oost-Nederland dhr. S. Iking. 



\section{De Gelderse arbeidsmarkt in vogelvlucht}

Ook in Gelderland lijken de jaren van grote economische voorspoed voorlopig voorbij te zijn. Omdat de arbeidsmarkt met enige vertraging reageert kan worden afgeleid dat de jaren met de grootste schaarste op de arbeidsmarkt voorlopig eveneens achter ons liggen. De grootste bedrijfssectoren in Gelderland zijn de dienstensectoren Handel en reparatie, Horeca en zakelijke dienstverlening (incl. uitzendwezen), Kwartaire diensten en Overheid en onderwijs. In deze sectoren werken in totaal ongeveer een half miljoen mensen, hetgeen circa $60 \%$ de werkzame beroepsbevolking van Gelderland is.

Een indicatie van de krapte op de Gelderse arbeidsmarkt kan worden verkregen door te kijken naar de positie van starters op de arbeidsmarkt in Gelderland ten opzichte van Nederland. Hieruit blijkt dat Gelderse gediplomeerde schoolverlaters van het MBO anderhalf jaar na het afronden van hun opleiding over het algemeen langer naar een baan zoeken. Indien zij echter een baan hebben gevonden, hebben zij een iets betere salariëring en is deze baan relatief vaak op hun eigen niveau en in de eigen vakrichting.

De verwachte arbeidsmarktontwikkelingen voor 2003 kunnen richtinggevend zijn voor de op korte termijn te ondernemen beleidsinspanningen. Hierbij kan onder meer worden gedacht aan een snelle bestrijding van de in hoog tempo oplopende werkloosheid die zich sinds enige tijd voordoet. Deze recente werkloosheidsstijging geeft aanleiding tot de vraag waar op de korte termijn de mogelijkheden liggen. Dit is van belang voor beleidsmakers bij het nemen van arbeidsmarktmaatregelen, voor werkgevers bij het bepalen van hun wervingsstrategie, en voor intermediairs bij het bemiddelen van personeel. Wanneer voor 2003 de totale vraag (de baanopeningen) wordt afgezet tegen de arbeidsmarktinstroom van schoolverlaters, dan zien we dat de grootste knelpunten in de personeelsvoorziening worden verwacht voor de Pedagogische beroepen en de (Para)medische beroepen vanwege de sterk achterblijvende instroom van schoolverlaters in deze beroepen, en in de Sociaalculturele beroepen vanwege de verwachte grote uitbreidingsvraag.

Ook voor schoolverlaters die binnenkort de arbeidsmarkt betreden kunnen de geschetste kortetermijnontwikkelingen informatief zijn bij de keuze van hun sollicitatiestrategie, of bij de eventuele afweging om door te studeren. In het laatste geval dienen bij de studiekeuze vooral de middellangetermijnprognoses tot 2006 in de afweging te worden betrokken. Daarnaast kunnen de middellangetermijnprognoses worden gebruikt door bijvoorbeeld onderwijsinstellingen bij het inrichten van de onderwijsinfrastructuur, en door werkgevers bij eventuele strategische beslissingen over hun rekruteringsbeleid. De verwachte grote arbeidsmarktinstroom van schoolverlaters van VMBO Landbouw en natuurlijke omgeving en VMBO Economie op de middellange termijn leidt naar verwachting tot een slecht arbeidsmarktperspectief voor deze schoolverlaters in 2006. Indien zij in dezelfde richting zouden doorstuderen in een MBO-opleiding, kunnen zij hun perspectief aanzienlijk verbeteren. Ook voor de andere MBO-sectoren (Techniek en 
Dienstverlening en gezondheidszorg) zijn de perspectieven van schoolverlaters voor de middellange termijn goed.

\subsection{Inleiding}

In dit hoofdstuk wordt ingegaan op de werkgelegenheidsstructuur en de ontwikkelingen op de Gelderse arbeidsmarkt. Daarbij wordt in paragraaf 1.2 eerst gekeken naar trends in de economische groei en de werkgelegenheid in Gelderland en Nederland. In paragraaf 1.3 komt de sectorale werkgelegenheidsstructuur aan de orde. In paragraaf 1.4 wordt er aandacht besteed aan de arbeidsmarktpositie van schoolverlaters in Gelderland ten opzichte van Nederland. Aansluitend zal in paragraaf 1.5 worden ingegaan op de verwachte arbeidsmarktontwikkelingen op hoofdlijnen. In de paragrafen 1.6 en 1.7 wordt specifiek ingegaan op de verwachte vraag- en aanbodontwikkelingen naar beroep en opleiding op respectievelijk de korte en de middellange termijn.

\subsection{Groeitrends in Gelderland en Nederland}

De economische groei in Nederland stagneert. Het Centraal Planbureau (CPB) verwacht dat de groei voor 2002 op slechts $0,25 \%$ voor 2002 zal uitkomen. ${ }^{3}$ In 2001 waren de voortekenen van deze terugval van de economie al aanwezig. Ook Gelderland ontkomt niet aan de neergaande conjunctuur. Figuur 1.1 geeft de dalende trend van de economische groei weer voor Gelderland en Nederland. Daarbij komt dat de economische groei sinds 1998 sterker daalt voor Gelderland dan voor Nederland.

Mede op basis van de regionaal-economische groeicijfers van Gelderland lijken de jaren van grote economische voorspoed voorlopig voorbij te zijn. Omdat de arbeidsmarkt met enige vertraging reageert kan worden afgeleid dat de jaren met de grootste schaarste op de arbeidsmarkt eveneens voorbij lijken te zijn. Werkgevers, waaronder de verschillende landelijke en regionale overheidsinstanties, zullen voor de vacatures die zij niet konden vervullen gedurende de afgelopen jaren, alsnog geschikt personeel proberen aan te stellen. Hierdoor ontstaat er eerst een na-ijl effect aan de vraagzijde van de arbeidsmarkt vanwege de vacatures die het moeilijkste te vervullen waren. Werkgevers zullen echter vanwege de onzekere conjuncturele ontwikkeling over de hele linie afwachtender zijn met het werven van nieuw personeel dan voorheen.

3. Zie de prognoses van het Centraal Planbureau in CPB Report 2002/4, Den Haag, december 2002. 
Figuur 1.1

De regionale economische groei (jaarlijkse groei van het volume van de toegevoegde waarde), in Gelderland en Nederland, 1995-2001

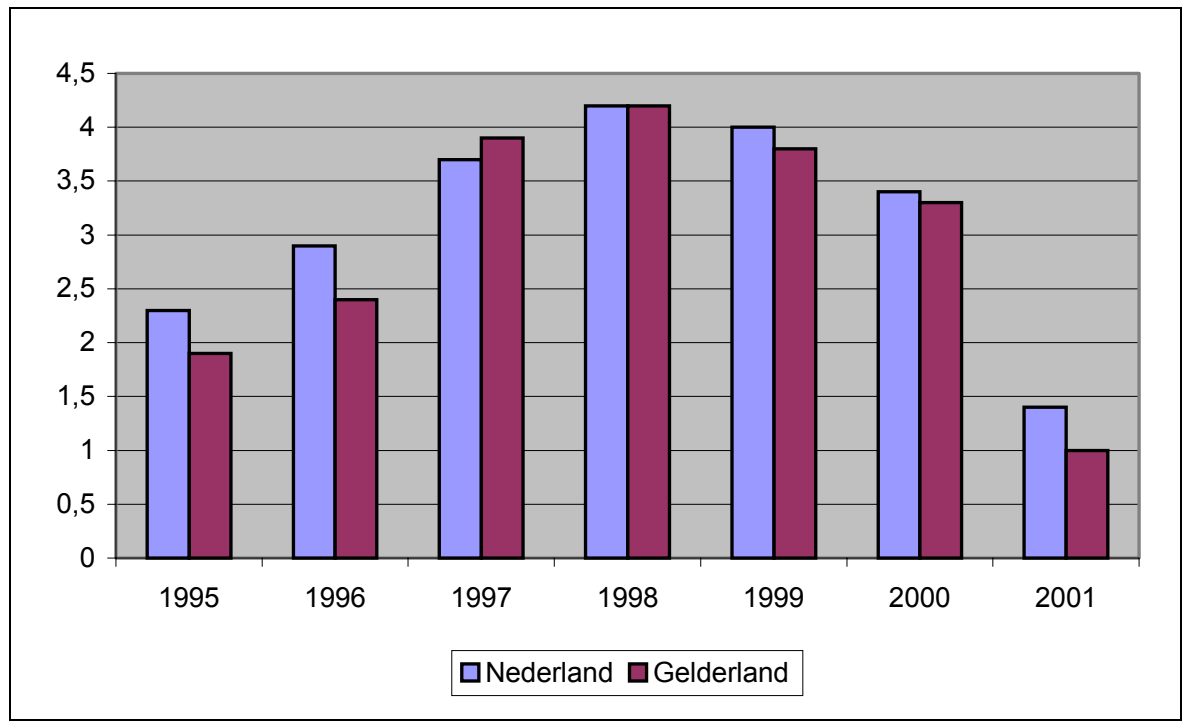

Bron: CBS/CPB/BEO

Een eventuele inkrimping van het vaste personeelsbestand is pas aan de orde als de omzet- en productiegroei op de wat langere termijn blijven tegenvallen. Deze zouden immers op korte termijn kunnen herstellen, waardoor er onnodig extra kosten gemaakt zouden moeten worden voor de personeelswerving. Naar verwachting zullen de werkenden met een flexibel arbeidscontract het eerst hun baan verliezen. Zij kunnen echter relatief snel worden aangenomen als de economie weer aantrekt. Verder kan de uitstoot van arbeid worden versneld door ouderen, maar ook arbeidsgehandicapten, sneller te laten uitstromen. Deze groepen zijn echter moeilijker aan het werk te helpen als de krapte op de arbeidsmarkt weer toeneemt.

Grote veranderingen in de ontwikkeling van de Gelderse werkgelegenheidsgroei zijn op zichzelf niet bijzonder. Uit figuur 1.2 blijkt dat de jaarlijkse groei van de werkzame beroepsbevolking in Gelderland na een bijzonder hoge groei in 1990 in de jaren 1991 tot en met 1994 relatief gering was. Toch komt de jaarlijkse groei nauwelijks onder de $1 \%$ uit over de gehele periode. Voorts blijkt uit de figuur dat de werkgelegenheidsgroei in Gelderland vooral vanaf 1995 gecorreleerd is aan die van Nederland. Ook in dit opzicht is de ontwikkeling van de werkgelegenheid in Gelderland niet bijzonder. 
Figuur 1.2

De groei van de werkzame beroepsbevolking (jaarlijkse groei in aantal personen) in Gelderland en Nederland, 1987-2001

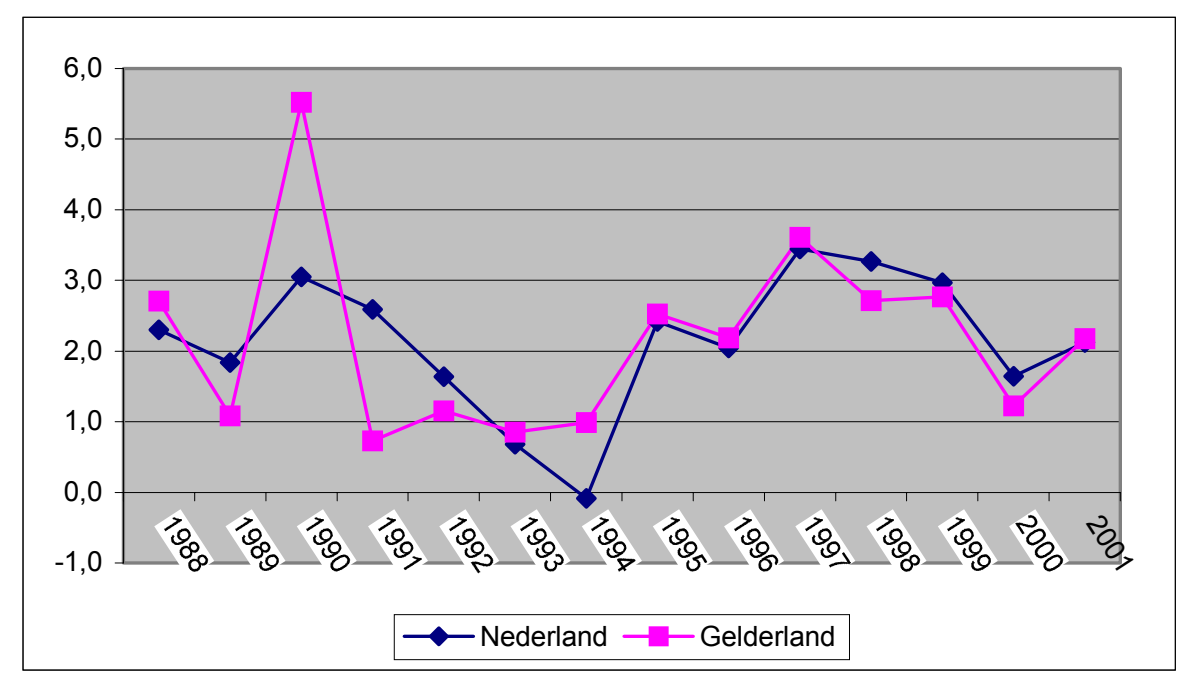

Bron: CBS

\subsection{Kenmerken en ontwikkeling van de werkzame beroepsbevolking in Gelderland}

Voor een beter inzicht in de Gelderse werkgelegenheidsontwikkeling wordt in deze paragraaf stilgestaan bij een aantal kenmerken van de werkgelegenheid van de beroepsbevolking in Gelderland. ${ }^{4}$ Tabel 1.1 geeft aan in welke bedrijfssectoren de beroepsbevolking van Gelderland werkzaam is. Bovendien worden het soort aanstelling en de achtergrondkenmerken naar leeftijd en geslacht weergegeven. De grootste bedrijfssectoren zijn de dienstensectoren Handel en reparatie, Horeca en zakelijke dienstverlening (incl. uitzendwezen), Kwartaire diensten (incl. gezondheidszorg) en Overheid en onderwijs. In deze sectoren werken in totaal ongeveer een half miljoen mensen, hetgeen circa $60 \%$ de werkzame beroepsbevolking van Gelderland is. Ten opzichte van Nederland zijn er in Gelderland relatief veel werkenden in de industriële sectoren Overige industrie (waaronder textiel-, hout-, paperindustrie en grafische industrie), Metaal en elektrotechniek en Voeding. Ook de werkgelegenheid in Bouw en onroerend goed is in Gelderland oververtegenwoordigd. Daarentegen zijn er relatief weinig werkenden in de bedrijfssectoren Energie, Chemie en Transport en communicatie. De sector Energie is bovendien erg klein en vertoont een sterk dalende trend in de werkgelegenheid gedurende de afgelopen jaren. Ook de werkgelegenheid in de agrarische sector is

4. Zie voor een uitgebreide beschrijving van de structuur en de ontwikkeling van de werkgelegenheid in Gelderland: Bureau Economisch Onderzoek, Provinciale Economische Verkenning 2003/2007, Provincie Gelderland, Arnhem, december 2002. Daarnaast bevat de Statistische Bijlage van het voorliggende rapport tevens een uitgebreide weergave van de diverse achtergrondkenmerken van de werkzame personen en hun arbeidscontract naar opleiding en beroep. 
sterk dalend. Overigens is deze dalende trend in de werkgelegenheid voor de twee laatstgenoemde sectoren overeenkomstig de landelijke trend. ${ }^{5}$

Tabel 1.1

Kenmerken van de werkzame beroepsbevolking in Gelderland, gemiddelde 2000-2001

\begin{tabular}{|c|c|c|c|}
\hline Bedrijfssector & $\begin{array}{c}\text { aantal } \\
\text { werkenden }\end{array}$ & $\begin{array}{c}\text { typering t.o.v. } \\
\text { Nederland }\end{array}$ & $\begin{array}{c}\text { trend } \\
1997-2001\end{array}$ \\
\hline $\begin{array}{l}\text { Landbouw en visserij } \\
\text { Voeding } \\
\text { Chemie } \\
\text { Metaal en elektrotechniek } \\
\text { Overige industrie } \\
\text { Energie } \\
\text { Bouw en onroerend goed } \\
\text { Handel en reparatie } \\
\text { Transport en communicatie } \\
\text { Bank- en verzekeringswezen } \\
\text { Horeca en zakelijke dienstverlening } \\
\text { Kwartaire diensten } \\
\text { Overheid en onderwijs } \\
\text { Totaal (incl. overig) }\end{array}$ & $\begin{array}{r}23.500 \\
21.500 \\
13.500 \\
52.000 \\
53.000 \\
4.000 \\
71.500 \\
127.500 \\
44.500 \\
32.500 \\
124.500 \\
136.000 \\
114.000 \\
837.000\end{array}$ & $\begin{array}{l}\text { gemiddeld } \\
\text { hoog } \\
\text { laag } \\
\text { hoog } \\
\text { zeer hoog } \\
\text { zeer laag } \\
\text { hoog } \\
\text { gemiddeld } \\
\text { laag } \\
\text { gemiddeld } \\
\text { gemiddeld } \\
\text { gemiddeld } \\
\text { gemiddeld } \\
\text { - }\end{array}$ & $\begin{array}{l}\text { sterk dalend } \\
\text { constant } \\
\text { constant } \\
\text { constant } \\
\text { constant } \\
\text { sterk dalend } \\
\text { stijgend } \\
\text { constant } \\
\text { stijgend } \\
\text { stijgend } \\
\text { stijgend } \\
\text { constant } \\
\text { constant } \\
\text { constant }\end{array}$ \\
\hline Leeftijd & $\begin{array}{r}\text { Gelderland } \\
\%\end{array}$ & $\begin{array}{r}\text { Nederland } \\
\%\end{array}$ & $\begin{array}{c}\text { trend } \\
1997-2001\end{array}$ \\
\hline $\begin{array}{l}\text { Jongeren }(15-29) \\
\text { Ouderen }(50-64)\end{array}$ & $\begin{array}{l}25 \\
20\end{array}$ & $\begin{array}{l}25 \\
19\end{array}$ & $\begin{array}{l}\text { dalend } \\
\text { stijgend }\end{array}$ \\
\hline Geslacht & $\begin{array}{r}\text { Gelderland } \\
\%\end{array}$ & $\begin{array}{r}\text { Nederland } \\
\%\end{array}$ & $\begin{array}{c}\text { trend } \\
1997-2001\end{array}$ \\
\hline Vrouwen & 39 & 40 & constant \\
\hline Contract & $\begin{array}{r}\text { Gelderland } \\
\%\end{array}$ & $\begin{array}{r}\text { Nederland } \\
\%\end{array}$ & $\begin{array}{c}\text { trend } \\
1997-2001\end{array}$ \\
\hline $\begin{array}{l}\text { Flexibel werk } \\
\text { Deeltijdwerk } \\
\text { Zelfstandigen }\end{array}$ & $\begin{array}{r}8 \\
32 \\
11\end{array}$ & $\begin{array}{r}8 \\
31 \\
11\end{array}$ & $\begin{array}{r}\text { dalend } \\
\text { stijgend } \\
\text { dalend }\end{array}$ \\
\hline
\end{tabular}

Bron: CBS/ROA

Wat betreft de kenmerken van de werkgelegenheid naar leeftijd, geslacht en soort aanstelling valt het op dat in Gelderland procentueel iets minder vrouwen en iets meer ouderen en deeltijders werken dan in Nederland. Gelderland volgt overigens de landelijke trend van vergrijzing en ontgroening wat betreft de stijging van het percentage ouderen en de daling van het percentage jongeren.

5. Zie ook ROA(2001), De arbeidsmarkt naar opleiding en beroep tot 2006, ROA-R-2001/8, Maastricht. 


\subsection{Arbeidsmarktdiscrepanties voor schoolverlaters van het MBO}

Een indicatie van de krapte op de Gelderse arbeidsmarkt kan ook worden verkregen door te kijken naar de positie van starters op de arbeidsmarkt in Gelderland ten opzichte van Nederland. In tabel 1.2 wordt dit gedaan voor gediplomeerde schoolverlaters van het MBO anderhalf jaar na het afronden van hun opleiding. In de tabel wordt onderscheid gemaakt tussen enerzijds 'open discrepanties' zoals de werkloosheid onder schoolverlaters en het bruto maandloon dat ze verdienen, en anderzijds 'verborgen discrepanties' zoals het moeten werken in deeltijd of in een flexibele aanstelling (korter dan één jaar, uitzendwerk), of het verrichten van werk onder het opleidingsniveau (onderbenutting) of buiten de eigen vakrichting (zie verder ook de Verklarende woordenlijst en paragraaf 2.4). Uit de gegevens van 2001 blijkt dat het percentage werkloze schoolverlaters in Gelderland weliswaar iets lager is, maar daar staat tegenover dat het percentage schoolverlaters dat 4 maanden na het afronden van de opleiding nog geen baan heeft, duidelijk hoger ligt dan landelijk. Dit betekent dat de schoolverlaters over het algemeen iets langer zoeken in Gelderland. Indien zij echter een baan hebben gevonden, hebben zij een betere salariëring en is deze baan relatief vaak op hun eigen niveau en in de eigen vakrichting. Een kanttekening daarbij is dat de schoolverlaters in Gelderland relatief vaak in deeltijd werken en minder snel een vast contract krijgen.

Tabel 1.2

Aansluiting tussen onderwijs en arbeidsmarkt van MBO-schoolverlaters, Gelderland en Nederland, 2001

\begin{tabular}{lcc}
\hline Discrepantie & Gelderland & Nederland \\
& $\%$ & $\%$ \\
\hline
\end{tabular}

Open discrepanties

werkloos

intredewerkloosheid minimaal 4 mnd.

bruto maandloon*

$\begin{array}{ll}1 & 2 \\ 7 & 4 \\ 1.500^{*} & 1.425^{*}\end{array}$

Verborgen discrepanties

flexibel werk

deeltijdwerk

onderbenutting

werk buiten eigen vakrichting

$\begin{array}{ll}27 & 21 \\ 32 & 28 \\ 34 & 41 \\ 26 & 31\end{array}$

*) In euro's.

Bron: ROA (SIS)

\subsection{De verwachte arbeidsmarktontwikkelingen in Gelderland op hoofdlijnen}

\section{Macrobeeld}

Het ziet er nu naar uit dat het herstel van de economie langer op zich laat wachten dan oorspronkelijk gedacht. Komt de economische groei volgens het CPB in 2002 naar verwachting slechts op $0,25 \%$ uit, voor 2003 wordt door het CPB een magere 
$0,75 \%$ verwacht. $^{6}$ De groeiverwachtingen voor Gelderland zijn momenteel respectievelijk $0 \%$ en $0,75 \% .^{7}$ De economische groei heeft directe consequenties voor de werkgelegenheidsgroei in Gelderland. Tabel 1.3 laat zien dat de verwachte werkgelegenheidsgroei voor 2003 in Gelderland 0,9\% bedraagt. $^{8}$ De verwachte werkgelegenheidsgroei leidt tezamen met de arbeidsmarktuitstroom ten gevolge van onder meer pensionering, de uitstroom vanwege ziekte of arbeidsongeschiktheid en de tijdelijke uittrede van vrouwen, tot het percentage baanopeningen van $5,5 \%$ in 2003. Omdat er een instroom van schoolverlaters op de arbeidsmarkt van $4,8 \%$ wordt verwacht, wordt er op basis van de bovenstaande een vraagoverschot voor 2003 verwacht.

Tabel 1.3

Verwachte macro arbeidsmarktontwikkeling (als percentage van de werkgelegenheid in het basisjaar), Gelderland en Nederland, in 2003 en in de periode 2001-2006

\begin{tabular}{lrrr}
\hline Kenmerk & $\begin{array}{r}\text { Gelderland } \\
2003 \\
\%\end{array}$ & $\begin{array}{r}\text { Gelderland } \\
2001-2006 \\
\%\end{array}$ & $\begin{array}{r}\text { Nederland } \\
2001-2006 \\
\%\end{array}$ \\
\hline Werkgelegenheidsgroei & 0,9 & 7 & 6 \\
Arbeidsmarktuitstroom & 4,6 & 25 & 24 \\
Baanopeningen & 5,5 & 32 & 30 \\
Instroom schoolverlaters & 4,9 & 25 & 25 \\
Vraagoverschot & 0,6 & 7 & 5 \\
\hline Bron: BEO/CPB/ROA & & &
\end{tabular}

Het is echter van groot belang op te merken dat de meest recente ontwikkelingen erop wijzen dat de werkgelegenheidsgroei in 2003 lager dan $0,9 \%$ uitvalt. Uit tabel 1.3 blijkt dat indien de werkgelegenheid in 2003 noch groeit noch krimpt, het vraagoverschot omslaat in een klein aanbodoverschot (0,3\%). De uitstroom van de arbeidsmarkt is dan immers te gering om het aanbod van schoolverlaters op de arbeidsmarkt op te vangen.

6. Zie CPB Report 2002/4, december 2002, Den Haag.

7. Bureau Economisch Onderzoek, Provinciale Economische Verkenning 2003/2007, Provincie Gelderland, Arnhem, december 2002.

8. De verwachte werkgelegenheidsgroei in deze rapportage is gebaseerd op prognoses van het Bureau Economisch Onderzoek (BEO) van de Provincie Gelderland. Het Nederlandse referentiekader voor de Gelderse prognoses wordt gevormd door de landelijke sectorontwikkeling zoals weergegeven in de studie De arbeidsmarkt naar opleiding en beroep tot 2006 van het ROA. Dit landelijke scenario is voor de Gelderse prognoses het uitgangspunt geweest. Hiermee is bereikt dat het rapport de Gelderse Arbeidsmarkt 20012006 consistent is met het landelijke rapport. Als gevolg van de recentelijk ingezette conjunctuuromslag is de hier geschetste werkgelegenheidsgroei van $0,9 \%$ voor 2003 waarschijnlijk aan de optimistische kant. Bureau Economisch Onderzoek heeft de ramingen voor 2003 en tot 2007 in de laatste Provinciale Economische Verkenning naar beneden bijgesteld tot respectievelijk $-0,25 \%$ en $0,75 \%$ (gemiddeld per jaar). Ook het CPB heeft de landelijke prognoses in december 2002 naar beneden bijgesteld (zie CPB Report 2002/4). Voor een verantwoording van de landelijke middellangetermijnprognoses zie $\mathrm{ROA}(2001)$, De arbeidsmarkt naar opleiding en beroep tot 2006, ROA-R-2001/8, Maastricht. 
Voor de middellange termijn wordt voorzien dat de werkgelegenheidsgroei zich herstelt. Dit betekent dat werkgelegenheidsgroei in 2003 lager ligt dan de verwachte groei op de middellange termijn, welke gemiddeld per jaar $1,4 \%$ bedraagt. Over de middellange termijn bezien ligt de Gelderse werkgelegenheidsgroei naar verwachting hoger dan landelijk. Bovendien de arbeidsmarktinstroom groter dan landelijk, mogelijk vanwege de relatief iets hogere arbeidsuittrede van ouderen in Gelderland (zie tabel 1.1). De instroom van schoolverlaters op de arbeidsmarkt voor de middellange termijn wijkt echter niet significant af van het landelijke beeld. Per saldo is daardoor de verwachte krapte op de arbeidsmarkt in 2006 voor Gelderland groter dan landelijk.

\section{Bedrijfssectoren}

Tabel 1.4 geeft voor de verschillende sectoren de uitbreidingsvraag op de korte en middellange termijn weer als percentage van de werkgelegenheid bij aanvang van de prognoseperiode. De tabel laat voor de werkgelegenheidsgroei in 2003 duidelijk en tweedeling zien tussen enerzijds de verwachte werkgelegenheidskrimp (of bijna nulgroei) in de agrarische sectoren en de industriële sectoren, en anderzijds de werkgelegenheidsgroei in de dienstverlenende sectoren. Daarmee lijkt voor Gelderland de werkgelegenheid in de dienstverlening beter bestand te zijn tegen de negatieve gevolgen van de tegenvallende conjuncturele ontwikkeling dan de werkgelegenheid in de industrie. Vooral de sectoren Kwartaire dienstverlening (incl. gezondheidszorg) en Overheid en onderwijs zijn voor 2003 de banenmotor. Opmerkelijk is dat de sector Bouw en onroerend goed relatief weinig last heeft van de neergang in de conjunctuur in 2003.

Voor de middellange termijn herstelt de werkgelegenheid in de industrie zich, met uitzondering van de bedrijfssectoren Overige industrie en Energie. Een aantal sectoren laten op de middellange termijn een aanzienlijk hogere werkgelegenheidsgroei zien dan landelijk, namelijk Metaal en elektrotechniek, Bouw en onroerend goed, en Horeca en zakelijke dienstverlening. Met name de laatste twee bedrijfssectoren zijn voor de totale Gelderse werkgelegenheidsgroei op de middellange termijn erg belangrijk. Twee sectoren zullen naar verwachting een significant slechtere werkgelegenheidsontwikkeling dan landelijk vertonen, namelijk de sectoren Energie en Bank en verzekeringswezen. 
Tabel 1.4

Verwachte uitbreidingsvraag (als percentage van de werkgelegenheid in het basisjaar) naar bedrijfssector in 2003 en in de periode 2001-2006, Gelderland en Nederland

\begin{tabular}{lrrr}
\hline Bedrijfssector & $\begin{array}{r}\text { Gelderland } \\
2003\end{array}$ & $\begin{array}{r}\text { Gelderland } \\
2001-2006\end{array}$ & $\begin{array}{r}\text { Nederland } \\
2001-2006 \\
\%\end{array}$ \\
& & & \\
& & & \\
& & -12 & -10 \\
Landbouw en visserij & $-3,2$ & 6 & 4 \\
Voeding & $-1,8$ & 3 & 4 \\
Chemie & $-1,0$ & 8 & -1 \\
Metaal en elektrotechniek & 0,2 & -6 & -4 \\
Overige industrie* & $-1,7$ & -6 & 2 \\
Energie* & $-1,7$ & 14 & 9 \\
Bouw en onroerend goed & 0,9 & 9 & 8 \\
Handel en reparatie & 0,9 & 8 & 5 \\
Transport en communicatie & 1,1 & -6 & -2 \\
Bank en verzekeringswezen & 0,4 & 19 & 14 \\
Horeca en zakelijke dienstverlening & 1,5 & 5 & 7 \\
Kwartaire diensten & 2,8 & 4 & 5 \\
Overheid en onderwijs & 1,4 & & \\
& & 7 & 6
\end{tabular}

$\left.{ }^{*}\right)$ Bij het maken van de Gelderse prognoses zijn de bedrijfssectoren Overige industrie en Energie samengenomen, waardoor zij hier dezelfde percentages hebben.

Bron: BEO/CPB/ROA

\subsection{De verwachte arbeidsmarktsituatie naar opleiding en beroep op de korte termijn}

De arbeidsmarktontwikkelingen op de korte termijn kunnen richtinggevend zijn voor de snel te ondernemen beleidsinspanningen. Hierbij kan onder meer worden gedacht aan een snelle bestrijding van de in hoog tempo oplopende werkloosheid die zich sinds enige tijd voordoet. Deze recente werkloosheidsstijging geeft aanleiding tot de vraag op waar op de korte termijn de mogelijkheden liggen. Dit is van belang voor beleidsmakers bij het nemen van arbeidsmarktmaatregelen, voor werkgevers bij het bepalen van hun wervingsstrategie, en voor intermediairs bij het bemiddelen van personeel. Ook voor schoolverlaters die binnenkort de arbeidsmarkt betreden kunnen de geschetste ontwikkelingen informatief zijn bij de keuze van hun sollicitatiestrategie, of bij de eventuele afweging om door te studeren. In het laatste geval dienen bij de studiekeuze vooral de middellangetermijnprognoses (zie de volgende paragraaf) in de afweging te worden betrokken. Daarnaast kunnen de middellangetermijnprognoses worden gebruikt door bijvoorbeeld onderwijsinstellingen bij het inrichten van de onderwijsinfrastructuur, en door werkgevers bij eventuele strategische beslissingen over hun rekruteringsbeleid.

Er dient echter tevens rekening te worden gehouden met de mogelijke grote verschillen in knelpunten in de personeelsvoorziening tussen de verschillende 
beroepsgroepen binnen één beroepsklasse, en in arbeidsmarktperspectieven tussen de verschillende opleidingstypen binnen één opleidingssector. Voor een verdere differentiatie van de informatie over de arbeidsmarktontwikkelingen en de knelpunten en perspectieven naar beroepsgroep en opleidingstype wordt verwezen naar de volgende hoofdstukken en naar de Statistische Bijlage van dit rapport.

Tabel 1.5

Arbeidsmarktprognoses per beroepsklasse (als percentage van de werkgelegenheid in 2002) en de knelpunten in de personeelsvoorziening voor werkgevers, Gelderland, 2003

Beroepsklasse $\begin{array}{rrrrr}\text { uitbreidings- } & \text { vervan- } & \text { instroom } & \text { ITKB* } & \text { typering } \\ \text { vraag } & \text { gings- } & \text { school- } & \text { knel- } \\ \% & \text { vraag } & \text { verlaters } & \text { punten } \\ & \% & \% & \end{array}$

Pedagogische beroepen

$\begin{array}{rrrrr}0,9 & 4,5 & 3,6 & 0,99 & \text { groot } \\ 1,0 & 3,7 & 5,7 & 1,03 & \text { enige } \\ -1,9 & 5,0 & 5,9 & 1,03 & \text { enige } \\ 0,3 & 3,8 & 4,7 & 1,01 & \text { enige } \\ 0,5 & 3,2 & 4,4 & 1,01 & \text { enige } \\ & & & & \\ 2,6 & 2,8 & 4,1 & 0,99 & \text { groot } \\ & & & & \\ 1,5 & 3,3 & 5,1 & 1,01 & \text { enige } \\ 3,3 & 1,6 & 4,4 & 1,00 & \text { groot } \\ 3,5 & 2,7 & 5,1 & 0,99 & \text { groot } \\ & & & & \\ 0,9 & 3,0 & 5,3 & 1,01 & \text { enige } \\ & & & & \\ -5,7 & 4,5 & 4,0 & 1,06 \text { vrijwel geen } \\ 0,9 & 3,4 & 4,9 & 1,01 & \text { enige }\end{array}$

Culturele beroepen

Agrarische beroepen

Technische en industrieberoepen

Transportberoepen

ITKB = Indicator Toekomstige Knelpunten in de personeelsvoorziening naar Beroep. Deze

Medische en paramedische

beroepen

Economisch-administratieve

beroepen

Informaticaberoepen

Sociaal-culturele beroepen

Verzorgende en dienstverlenende

beroepen

Openbare orde- en

veiligheidsberoepen

Totaal (incl. hogere beroepen)

$0,9 \quad 3,4$ indicator geeft aan in welke mate werkgevers problemen ondervinden bij het aantrekken van geschikt personeel. Naarmate de waarde van de ITKB lager is, zijn er meer knelpunten te verwachten (zie Verklarende woordenlijst).

Bron: BEO/CBS/CPB/ROA

Tabel 1.5 laat de verwachte arbeidsmarktontwikkelingen op de korte termijn zien voor de verschillende beroepsklassen. Naast de dalende werkgelegenheid in de Agrarische beroepen zal naar verwachting in 2003 alleen de werkgelegenheid in de Openbare orde- en veiligheidsberoepen dalen. Deze beroepsklasse is echter relatief klein, waardoor er snel grotere procentuele fluctuaties in de werkgelegenheid kunnen optreden. De werkgelegenheidsgroei zal daarentegen bijzonder sterk zijn in de Medische en paramedische beroepen, de Sociaal-culturele beroepen en de Informaticaberoepen. De vervangingsvraag is bijzonder laag voor de Informaticaberoepen. De lage vervangingsvraag in deze beroepsklasse kan worden verklaard door het relatief hoge percentage jongeren. Daarentegen is de vervangingsvraag bijzonder hoog in de Agrarische beroepen, de Pedagogische beroepen en de Openbare orde en veiligheidsberoepen. Voor de twee eerstgenoemde beroepsklassen kan de 
reden hiervoor gelegen zijn in het hoge percentage ouderen. Voor de Openbare orde- en veiligheidsberoepen is de oorzaak voor een relatief groot verloop niet duidelijk. Zo zouden bijvoorbeeld een combinatie van relatief zware psychische en fysieke belastingsfactoren tijdens het werk een rol kunnen spelen, maar ook een eventueel gebrek aan carrièreperspectief. ${ }^{9}$

De arbeidsmarktinstroom van schoolverlaters is in 2003 gemiddeld 4,9\%. Belangrijkste uitschieters in de instroom in de verschillende beroepsklassen zijn de Culturele beroepen en de Agrarische beroepen met een hoge instroom van respectievelijk $5,7 \%$ en $5,9 \%$ en de Pedagogische beroepen en (Para)medische beroepen met een lage instroom van respectievelijk $3,6 \%$ en $4,1 \%$.

Wanneer de totale vraag (de baanopeningen) wordt afgezet tegen de instroom, zien we dat de grootste knelpunten in de personeelsvoorziening worden verwacht voor de Pedagogische beroepen en de (Para)medische beroepen vanwege de sterk achterblijvende instroom van schoolverlaters in deze beroepen, en in de Sociaalculturele beroepen vanwege de verwachte grote uitbreidingsvraag.

Tabel 1.6

Arbeidsmarktprognoses per opleidingssector (als percentage van de werkgelegenheid in 2002) en de arbeidsmarktperspectieven voor schoolverlaters, Gelderland, 2003

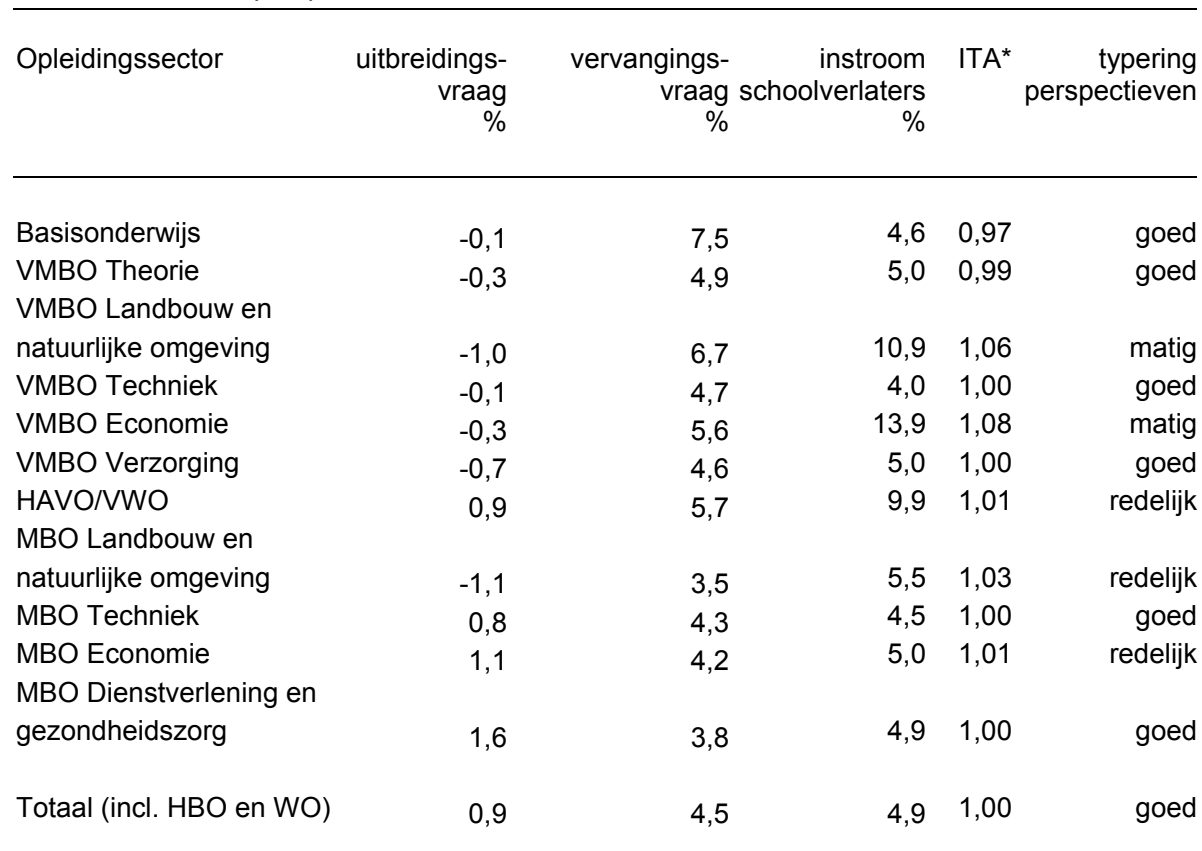

*) ITA = Indicator Toekomstige Arbeidsmarktperspectieven. De ITA geeft de verhouding tussen aanbod en vraag in de prognoseperiode weer. Naarmate de waarde van de indicator hoger is, is het perspectief slechter (zie Verklarende woordenlijst).

Bron: BEO/CBS/CPB/ROA

9. Zie hierover ook het onderzoek van E.S.W. Wennekes en E. Backx (2003), De particuliere beveiligingsbranche onder de loep, Twee studies gedaan in opdracht van vakbond De Unie, Wetenschapswinkel Universiteit van Tilburg. 
Tabel 1.6 geeft een overzicht van vraag en aanbod in Gelderland in 2003 voor de lagere en middelbare opleidingen. De tabel laat zien dat de werkgelegenheid krimpt voor de ongeschoolden en de lager opgeleiden. Daarnaast laat vooral de werkgelegenheid voor de agrarisch opgeleiden, zowel op VMBO- als op MBOniveau, een forse krimp zien. De negatieve uitbreidingsvraag voor deze opleidingssectoren wordt echter gecompenseerd door de relatief hoge vervangingsvraag naar lager opgeleiden. De oorzaken voor deze hoge vervangingsvraag zijn gelegen in een relatief grote uitstroom van de arbeidsmarkt, en in de doorstroom naar een betere baan door middel van post-initiële scholing van lager opgeleide werkenden, waardoor baanopeningen voor andere ongeschoolden en lager opgeleiden ontstaan. Hieruit blijkt dat het goede perspectief dat de Indicator Toekomstig Arbeidsmarktperspectief (ITA) voor Basisonderwijs en een aantal opleidingssectoren van het $\mathrm{VMBO}$ aangeeft, gerelativeerd moet worden.

De instroom van schoolverlaters op de arbeidsmarkt is met name hoog voor VMBO landbouw en natuurlijke omgeving, VMBO Economie en HAVO/VWO. Onder meer hierdoor is het arbeidsmarktperspectief voor schoolverlaters van VMBO landbouw en natuurlijk omgeving en $V M B O$ economie matig. Over het algemeen zijn de perspectieven voor schoolverlaters in 2003 redelijk tot goed.

\subsection{De verwachte arbeidsmarktsituatie naar opleiding en beroep op de middellange termijn}

Tabel 1.7 geeft een overzicht van de vraag- en aanbodkant van de Gelderse arbeidsmarkt in de periode 2001-2006. Alleen voor de Agrarische beroepen en de Openbare orde- en veiligheidsberoepen wordt voor de periode 2001-2006 een werkgelegenheidskrimp verwacht. Voor de Pedagogische beroepen zijn de knelpunten in de personeelsvoorziening groot vanwege de grote vervangingsvraag in combinatie met de lage arbeidsmarktinstroom van schoolverlaters. Voor de Economische-administratieve beroepen, de Informaticaberoepen en de Sociaalculturele beroepen zijn de knelpunten groot vanwege de verwachte grote uitbreidingsvraag. De verwachte grote knelpunten op de korte termijn in de Paramedische en medische beroepen zullen naar verwachting op de middellange termijn duidelijk minder groot worden door een verwachte grote vertraging in de werkgelegenheidsgroei. De recruteringsproblematiek voor Gelderse werkgevers binnen deze beroepen zal verwachting slechts een kortetermijnprobleem zijn. Tabel 1.7 laat zien dat naar verwachting alleen voor de Culturele beroepen, de Agrarische beroepen en de Openbare orde- en veiligheidsberoepen de knelpunten in de personeelsvoorziening voor werkgevers vrijwel nihil zullen zijn. 
Tabel 1.7

Arbeidsmarktprognoses per beroepsklasse (als percentage van de werkgelegenheid in 2001) en de knelpunten in de personeelsvoorziening voor werkgevers, Gelderland, 2001-2006

\begin{tabular}{|c|c|c|c|c|c|}
\hline Beroepsklasse & $\begin{array}{r}\text { uitbreidings- } \\
\text { vraag } \\
\%\end{array}$ & $\begin{array}{r}\text { vervangings- } \\
\text { vraag } \\
\%\end{array}$ & $\begin{array}{r}\text { instroom } \\
\text { school- } \\
\text { verlaters } \\
\%\end{array}$ & ITKB* & $\begin{array}{r}\text { typering } \\
\text { knelpunten }\end{array}$ \\
\hline Pedagogische beroepen & 1 & 23 & 17 & 0,95 & groot \\
\hline Culturele beroepen & 5 & 18 & 28 & 1,05 & vrijwel geen \\
\hline Agrarische beroepen & -6 & 25 & 27 & 1,07 & vrijwel geen \\
\hline Technische en & & & & & \\
\hline industrieberoepen & 3 & 19 & 23 & 1,03 & enige \\
\hline Transportberoepen & 4 & 16 & 23 & 1,03 & enige \\
\hline $\begin{array}{l}\text { Medische en paramedische } \\
\text { beroepen } \\
\text { Economisch-administratieve }\end{array}$ & 2 & 14 & 20 & 1,04 & enige \\
\hline beroepen & 12 & 16 & 26 & 0,99 & groot \\
\hline Informaticaberoepen & 20 & 8 & 22 & 0,96 & groot \\
\hline Sociaal-culturele beroepen & 18 & 14 & 26 & 0,97 & groot \\
\hline $\begin{array}{l}\text { Verzorgende en dienst- } \\
\text { verlenende Beroepen } \\
\text { Openbare orde- en veiliaheids- }\end{array}$ & 3 & 15 & 27 & 1,08 & vrijwel geen \\
\hline beroepen & -3 & 22 & 20 & 1,01 & enige \\
\hline $\begin{array}{l}\text { Totaal (incl. hogere } \\
\text { beroepen) }\end{array}$ & 6 & 17 & 25 & 1,02 & enige \\
\hline
\end{tabular}

$\left.{ }^{\star}\right)$ ITKB = indicator Toekomstige Knelpunten in de personeelsvoorziening naar Beroep. Deze indicator geeft aan in welke mate werkgevers problemen ondervinden bij het aantrekken van geschikt personeel. Naarmate de waarde van de ITKB lager is, zijn er meer knelpunten te verwachten (zie Verklarende woordenlijst).

Bron: BEO/CBS/CPB/ROA

Tabel 1.8 geeft een overzicht van de vraag- en aanbodkant van de Gelderse arbeidsmarkt in de periode 2001-2006 naar opleidingssector. De verwachte uitbreidingvraag is voor de lagere opleidingen (tot en met het VMBO) veelal negatief. De verwachte grote arbeidsmarktinstroom van schoolverlaters van VMBO Landbouw en natuurlijke omgeving en VMBO Economie leidt tot een slecht arbeidsmarktperspectief voor deze schoolverlaters. Indien zij in dezelfde richting zouden doorstuderen voor een MBO-opleiding, kunnen zij hun perspectief aanzienlijk verbeteren. Voor ongeschoolden met alleen Basisonderwijs en in iets mindere mate ook voor de verschillende $\mathrm{VMBO}$-opleidingsrichtingen lijkt het perspectief gunstig te zijn, maar hierbij geldt dezelfde kanttekening als die eerder is gemaakt. Ongeschoolden en lager opgeleiden komen veelal in zogenaamde 'dead-end jobs' terecht onder relatief slechte arbeidsvoorwaarden en zonder veel carrièreperspectief. De doorstroom van ongeschoolde en laagopgeleide werkenden door middel van het volgen van postinitiële scholing naar een hoger opleidingsniveau is heel gebruikelijk. ${ }^{10}$ Hierdoor ontstaat er vervangingsvraag naar nieuw (jonge) personeel zonder veel voorop-

10. Zie ook hoofdstuk 5 in ROA (2001), De arbeidsmarkt naar opleiding en beroep tot 2006, ROA-R-2001/8, Maastricht. 
leiding. Zonder adequate omscholing dreigt er op termijn uittrede van de arbeidsmarkt en non-participatie.

Tabel 1.8

Arbeidsmarktprognoses per opleidingssector (als percentage van de werkgelegenheid in 2000) en de arbeidsmarktperspectieven voor schoolverlaters, Gelderland, 2001-2006

\begin{tabular}{|c|c|c|c|c|c|}
\hline Opleidingssector & $\begin{array}{r}\text { uitbreidings- } \\
\text { vraag } \\
\%\end{array}$ & $\begin{array}{r}\text { vervangings- } \\
\text { vraag } \\
\%\end{array}$ & $\begin{array}{r}\text { instroom } \\
\text { school- } \\
\text { verlaters } \\
\%\end{array}$ & ITA $^{*}$ & $\begin{array}{r}\text { typering } \\
\text { perspectieven }\end{array}$ \\
\hline Basisonderwijs & -20 & 39 & 23 & 0,89 & goed \\
\hline VMBO Theorie & 1 & 25 & 25 & 1,00 & goed \\
\hline \multicolumn{6}{|l|}{ VMBO Landbouw en } \\
\hline natuurlijke omgeving & -28 & 34 & 54 & 1,17 & slecht \\
\hline VMBO Techniek & -9 & 24 & 20 & 0,97 & goed \\
\hline VMBO Economie & -14 & 28 & 69 & 1,32 & slecht \\
\hline VMBO Verzorging & -8 & 24 & 25 & 1,01 & redelijk \\
\hline HAVO/VWO & 17 & 29 & 50 & 1,03 & redelijk \\
\hline \multicolumn{6}{|l|}{ MBO Landbouw en } \\
\hline natuurlijke omgeving & 15 & 17 & 28 & 0,97 & goed \\
\hline MBO Techniek & 13 & 21 & 23 & 0,92 & goed \\
\hline \multicolumn{6}{|l|}{$\begin{array}{l}\text { MBO Economie } \\
\text { MBO Dienstverlening en }\end{array}$} \\
\hline $\begin{array}{l}\text { MBO Dienstverlening en } \\
\text { gezondheidszorg }\end{array}$ & 7 & 19 & 25 & 0,98 & goed \\
\hline Totaal (incl. HBO en WO) & 6 & 39 & 25 & 0,95 & goed \\
\hline
\end{tabular}

$\left.{ }^{\star}\right)$ ITA = Indicator Toekomstige Arbeidsmarktperspectieven. De ITA geeft de verhouding tussen aanbod en vraag in de prognoseperiode weer. Naarmate de waarde van de indicator hoger is, is het perspectief slechter (zie Verklarende woordenlijst).

Bron: BEO/CBS/CPB/ROA

Over het algemeen worden er gunstige perspectieven voor schoolverlaters van het MBO verwacht. Ook hier blijft het echter van belang in te zien dat binnen een bepaalde opleidingssector er ook opleidingsrichtingen kunnen voorkomen met minder goede arbeidsmarktperspectieven voor schoolverlaters (zie hoofdstuk 4 en de Statistische Bijlage). 


\section{Het beroepsonderwijs in Gelderland}

In dit hoofdstuk staat het Gelders beroepsonderwijs centraal. De nadruk ligt hierbij op het in kaart brengen van het huidig en toekomstig aanbod van lager en middelbaar opgeleiden op de Gelderse arbeidsmarkt. Ruim 12.000 VMBO'ers hebben hun opleiding in 2001 succesvol afgerond. Hiermee is het aantal gediplomeerden ongeveer constant vergeleken met het jaar 2000. Bijna de helft van de VMBO'ers heeft een opleiding volgens de theoretische leerweg gevolgd. Ruim 13.500 MBO'ers hebben hun diploma gehaald. Dit is zo'n 600 minder dan in het jaar 2000. De meeste Gelderse MBO'ers hebben een opleiding in de sector MBO Dienstverlening en gezondheidszorg gevolgd. In deze sector is er, in tegenstelling tot de algemene trend in Gelderland, bovendien sprake van een toename van het aantal gediplomeerden. lets minder dan $40 \%$ van de gediplomeerden heeft een BBL-opleiding gevolgd. Het aandeel BBL'ers is het grootst in de sector MBO Techniek, waar ruim $60 \%$ van de gediplomeerden heeft gekozen voor een beroepsbegeleidend traject. In de sector $M B O$ Economie daarentegen heeft ongeveer $75 \%$ van de gediplomeerden een $B O L-$ opleiding gevolgd.

Het aantal VMBO-leerlingen is in 2001 iets hoger dan in 2000. Het overgrote deel van de leerlingen (meer dan 100.000 leerlingen) volgt de theoretische leerweg of zit in de eerste twee jaar van de opleiding (de zogenaamde basisvorming). Het aantal leerlingen in het MBO is met zo'n 50.000 leerlingen min of meer constant. Ook zijn er nauwelijks verschuivingen waar te nemen in het aantal leerlingen binnen de verschillende sectoren. De sectoren MBO Techniek en MBO Dienstverlening en gezondheidszorg zijn met meer dan 16.000 leerlingen het grootst. In populariteit groeiende opleidingen zijn MBO ICT, MBO Verpleging en verzorging, $M B O$ Beweging en therapie en MBO Toerisme en recreatie. Ongeveer $35 \%$ van de Gelderse MBO'ers volgt een opleiding volgens de meer praktisch georiënteerde beroepsbegeleidende leerweg.

De Gelderse arbeidsmarkt voor MBO-schoolverlaters wordt in 2001 gekenmerkt door een grote krapte. Het tekort aan schoolverlaters heeft ertoe geleid dat de werkloosheid erg laag is en de lonen sterk stijgen. De werkloosheid onder Gelderse $\mathrm{MBO}$-schoolverlaters is in alle onderwijssectoren niet hoger dan $2 \%$. De lonen van starters op de arbeidsmarkt met een MBO-diploma zijn gestegen van gemiddeld ruim $€ 1.200$ per maand in 2000 tot maar liefst $€ 1.500$ in 2001. Dit is een stijging van meer dan $20 \%$. De signalen van de toegenomen krapte waren in Gelderland zelfs sterker dan landelijk. Mede als gevolg hiervan is het gemiddeld loonpeil in Gelderland voor het eerst sinds jaren hoger dan landelijk. De krapte op de arbeidsmarkt komt ook tot uiting in de geringe omvang van de flexibele arbeidsmarkt. Het aandeel van flexibele arbeidskrachten in Gelderland is gedaald van 47\% in 1996 naar $27 \%$ in 2001.

Onderbenutting vormt een niet te onderschatten fenomeen op zowel de Gelderse als de landelijke arbeidsmarkt voor MBO-schoolverlaters. Meer dan 30\% van de MBOschoolverlaters is onder zijn of haar niveau werkzaam In 2001 is in Gelderland 34\% 
van de schoolverlaters onder MBO-niveau werkzaam; landelijk is dit met $41 \%$ wat hoger. In Gelderland heeft $26 \%$ van de $\mathrm{MBO}$-schoolverlaters emplooi gevonden in een baan die minder goed aansluit bij de gevolgde opleidingsrichting. In de rest van het land is dit met $31 \%$ hoger. Dit percentage is de laatste jaren landelijk min of meer constant. In Gelderland is er daarentegen sprake van een aanzienlijke daling. In 1999 was nog 43\% van de Gelderse schoolverlaters buiten zijn of haar eigen richting werkzaam.

\subsection{Inleiding}

In dit hoofdstuk staat het Gelderse beroepsonderwijs centraal. De opzet van dit hoofdstuk is als volgt. In paragraaf 2.2 wordt aandacht geschonken aan het aantal leerlingen dat recent een opleiding in het beroepsonderwijs succesvol heeft afgerond. Dit aantal gediplomeerden geeft inzicht in het huidig aanbod van VMBO'ers en MBO'ers in Gelderland. In paragraaf 2.3 wordt aandacht geschonken aan het aantal leerlingen dat momenteel in Gelderland een opleiding op VMBO- of MBO-niveau volgt. Inzicht in dit aantal leerlingen 'in de pijplijn' geeft een eerste indicatie van het toekomstig aanbod van schoolverlaters voor vervolgopleidingen of voor de arbeidsmarkt in Gelderland. Tenslotte wordt in paragraaf 2.4 de huidige arbeidsmarktpositie van de $\mathrm{MBO}$-schoolverlaters in kaart gebracht. Het gaat hierbij zowel om de voor de hand liggende indicatoren, zoals werkloosheid en beloning (de 'open' discrepanties) als om wat minder directe maatstaven zoals de inhoudelijke aansluiting en de duur van het contract (de 'verborgen' discrepanties).

\subsection{Het aantal gediplomeerden in Gelderland}

Het aantal gediplomeerden geeft een indicatie van het huidige aanbod van schoolverlaters voor vervolgopleidingen en voor de Gelderse arbeidsmarkt. In tabel 2.1 wordt een overzicht gegeven van het aantal gediplomeerden in Gelderland naar onderwijssector. Uit de tabel blijkt dat ruim 12.000 VMBO'ers hun opleiding in 2001 succesvol hebben afgerond. Hiermee is het aantal gediplomeerden ongeveer constant vergeleken met het jaar 2000. Bijna de helft van de VMBO'ers heeft een opleiding volgens de theoretische leerweg gevolgd. In feite betreft het hier MAVOschoolverlaters die voor de herstructurering van het VBO en de MAVO aan hun opleiding zijn begonnen. VMBO Theorie kan worden beschouwd als de opvolger van de MAVO-opleiding.

Uit de tabel blijkt tevens dat er in Gelderland in 2001 ruim 13.500 MBO'ers hun opleiding succesvol hebben afgerond. Dit is zo'n 600 schoolverlaters minder dan in 2000. De meeste Gelderse MBO'ers hebben een opleiding in de sector MBO Dienstverlening en gezondheidszorg gevolgd. In deze sector is er, tegen de algemene trend in, bovendien sprake van een toename van het aantal gediplomeerden. Binnen de sector MBO Dienstverlening en gezondheidszorg zit vooral de opleiding $M B O$ Verpleging en verzorging met een toename van 350 gediplomeerden in de lift. In de sectoren MBO Techniek en MBO Economie is er sprake van een afname van het aantal gediplomeerden. Met name in de sector MBO Economie is deze afname aanzienlijk. Binnen de sector MBO Economie dragen vooral de 
opleidingen MBO Administratie en Logistiek en MBO Handel bij aan de afname van de uitstroom. De afname bedraagt respectievelijk 400 en 375 gediplomeerden. Binnen de sector MBO Techniek lijkt over vrijwel de hele linie sprake van een geringe daling. De belangrijkste uitzonderingen zijn de opleidingen MBO Grond-, weg- en waterbouw, MBO Installatietechniek en MBO ICT waar het aantal gediplomeerden in 2001 wel is toegenomen.

Tabel 2.1

Aantal gediplomeerden van het VMBO en het $\mathrm{MBO}$ in Gelderland naar onderwijssector, kalenderjaar 2000 en 2001

\begin{tabular}{|c|c|c|}
\hline \multirow[b]{2}{*}{ Opleidingssector } & \multicolumn{2}{|c|}{ Aantal gediplomeerden } \\
\hline & 2000 & 2001 \\
\hline VMBO Theorie & 5.200 & 5.000 \\
\hline VMBO Landbouw en natuurlijke omgeving* & 350 & 800 \\
\hline VMBO Techniek & 2.800 & 2.800 \\
\hline VMBO Zorg en Welzijn & 1.875 & 1.900 \\
\hline VMBO Economie & 1.500 & 1.525 \\
\hline VMBO Totaal & 11.925 & 12.125 \\
\hline HAVO/VWO & 7.650 & 6.350 \\
\hline MBO Landbouw en natuurlijke omgeving* & 1.075 & 1.375 \\
\hline MBO Techniek & 4.575 & 4.250 \\
\hline MBO Dienstverlening en gezondheidszorg & 4.900 & 5.175 \\
\hline MBO Economie & 3.625 & 2.750 \\
\hline MBO Totaal & 14.250 & 13.675 \\
\hline
\end{tabular}

Tabel 2.2

Aantal gediplomeerden van het MBO in Gelderland naar leerweg en onderwijssector, kalenderjaar 2001

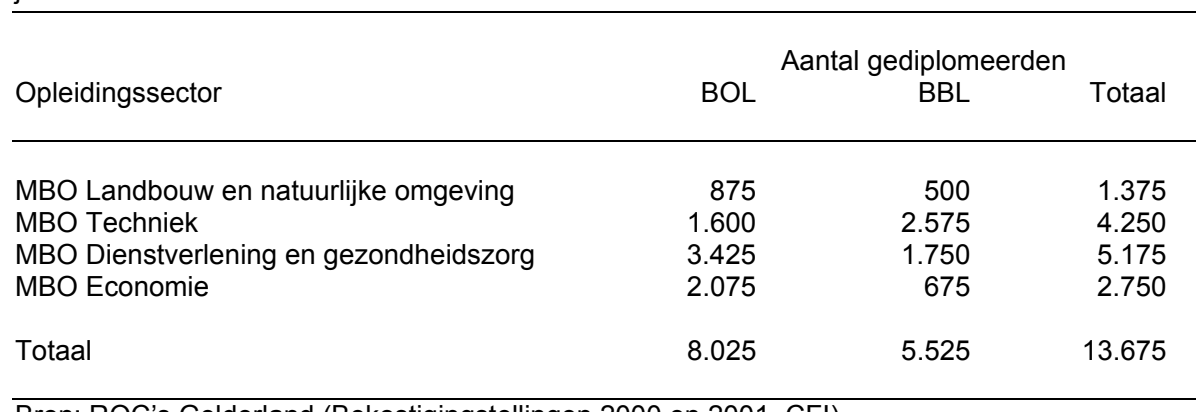

Bron: ROC's Gelderland (Bekostigingstellingen 2000 en 2001, CFI)

In tabel 2.2 wordt de succesvolle uitstroom uit de MBO-opleidingen uitgesplitst naar leerweg. Zo'n 40\% van de gediplomeerden heeft een BBL-opleiding gevolgd. Het aandeel BBL'ers is het grootst in de sector MBO Techniek, waar ruim $60 \%$ van de gediplomeerden heeft gekozen voor een beroepsbegeleidend traject. In de sector 
MBO Economie daarentegen heeft ongeveer $75 \%$ van de gediplomeerden een BOLopleiding gevolgd.

\subsection{Het aantal leerlingen in Gelderland}

Het aantal leerlingen in het VMBO en het MBO geeft inzicht in hetgeen er 'in de pijplijn' zit. Met andere woorden: met behulp van het aantal leerlingen kan een eerste indicatie worden gegeven van het toekomstig aanbod voor vervolgopleidingen en voor de arbeidsmarkt in Gelderland. Tabel 2.3 laat zien dat het aantal VMBOleerlingen in 2001 iets hoger is dan in 2000. Het overgrote deel van de leerlingen (meer dan 100.000 leerlingen) volgt de theoretische leerweg of zit in de eerste twee jaar van de opleiding (de zogenaamde basisvorming).

Uit de tabel blijkt ook dat het aantal leerlingen in het MBO met zo'n 50.000 leerlingen min of meer constant is. Ook zijn er nauwelijks verschuivingen waar te nemen in het aantal leerlingen binnen de verschillende sectoren. De sectoren MBO Techniek en MBO Dienstverlening en gezondheidszorg zijn met meer dan 16.000 leerlingen het grootst. MBO Economie blijft hier met 12.000 leerlingen iets bij achter. De sector $M B O$ Landbouw en natuurlijke omgeving is het kleinst.

Tabel 2.3

Aantal (bekostigde) leerlingen in het VMBO en het MBO in Gelderland naar onderwijssector, kalenderjaar 2000 en 2001

\begin{tabular}{|c|c|c|}
\hline \multirow[b]{2}{*}{ Opleidingssector } & \multicolumn{2}{|c|}{ Aantal leerlingen } \\
\hline & 2000 & 2001 \\
\hline VMBO Theorie en basisvorming & 105.150 & 103.025 \\
\hline VMBO Landbouw en natuurlijke omgeving & 2.700 & 2.850 \\
\hline VMBO Techniek & 11.300 & 11.775 \\
\hline VMBO Zorg en welzijn & 7.300 & 7.550 \\
\hline VMBO Economie & 8.100 & 11.975 \\
\hline VMBO Totaal & 135.775 & 138.625 \\
\hline HAVO/VWO & 67.675 & 71.150 \\
\hline MBO Landbouw en natuurlijke omgeving & 3.475 & 3.350 \\
\hline MBO Techniek & 16.525 & 16.800 \\
\hline MBO Dienstverlening en gezondheidszorg & 16.750 & 16.625 \\
\hline MBO Economie & 12.450 & 12.075 \\
\hline MBO Totaal & 49.450 & 49.275 \\
\hline \multicolumn{3}{|c|}{ Bron: Onderwijsinstellingen Gelderland (Bekostigingstellingen 2000 en 2001, CFI) } \\
\hline \multicolumn{3}{|c|}{$\begin{array}{l}\text { Binnen de sector } M B O \text { Techniek stijgt de opleiding } M B O \text { ICT het snelst in } \\
\text { populariteit. In één jaar heeft deze opleiding er meer dan } 500 \text { leerlingen bij gekregen. } \\
\text { Opleidingen als } M B O \text { Bouw en } M B O \text { Elektrotechniek leiden daarentegen in } 2001 \\
\text { minder leerlingen op dan in } 2000 \text {. Voor MBO Bouw is het leerlingaantal zelfs met } \\
\text { meer dan } 200 \text { gedaald. Binnen de sector MBO Dienstverlening en gezondheidszorg } \\
\text { nemen de opleidingen } M B O \text { Verpleging en verzorging en } M B O \text { Beweging en therapie } \\
\text { wat in populariteit toe. Het aantal leerlingen is met } 125 \text { gestegen. Het aantal } \\
\text { leerlingen dat de opleiding } M B O \text { sociaal-pedagogisch en welzijn volgt is daarentegen }\end{array}$} \\
\hline
\end{tabular}


met 150 gedaald. Binnen de sector MBO Economie groeit de opleiding MBO toerisme en recreatie. In vergelijking met 2000 heeft deze opleiding er in 2001 maar liefst 275 leerlingen bij gekregen in Gelderland. De opleiding MBO Handel heeft daarentegen 250 leerlingen verloren.

In tabel 2.4 wordt voor het MBO een uitsplitsing gemaakt naar leerweg. Ongeveer $35 \%$ van de Gelderse MBO'ers volgt een opleiding volgens de meer praktisch georiënteerde beroepsbegeleidende leerweg. Dit percentage is wat lager dan het percentage BBL-gediplomeerden, zoals dat in tabel 2.2 werd gepresenteerd. Dit kan erop wijzen dat de populariteit van het BBL wat afneemt. Het kan er daarnaast ook op wijzen dat de uitval in het BOL wat hoger is dan in het BBL. Helaas ontbreken de gegevens om hier een gefundeerde uitspraak over te doen.

Opvallend is dat in de sector MBO Techniek meer dan de helft van de leerlingen een BOL-opleiding volgt. Hiermee is het aandeel leerlingen dat een technische opleiding volgt groter dan het aandeel gediplomeerden van de sector MBO Techniek. Dit kan erop wijzen dat in de sector techniek de uitval uit de BOL-opleidingen relatief groot is. Wellicht is het raadzaam leerlingen meer op de mogelijkheden in het BBL, dat gezien het meer praktische en daarmee laagdrempelige karakter een belangrijke rol kan vervullen in het streven iedereen een startkwalificatie te laten behalen, te wijzen. In de sectoren MBO Dienstverlening en gezondheidszorg en MBO Economie is het aantal leerlingen in de verschillende leerwegen meer in balans met het aantal gediplomeerden.

Tabel 2.4

Aantal (bekostigde) leerlingen in het MBO in Gelderland naar leerweg en onderwijssector, kalenderjaar 2001

\begin{tabular}{lrrr}
\hline Opleidingssector & \multicolumn{3}{c}{ Aantal leerlingen } \\
& BOL & BBL & Totaal \\
\hline MBO Landbouw en natuurlijke omgeving & 2.375 & 975 & 3.350 \\
MBO Techniek & 8.700 & 8.125 & 16.800 \\
MBO Dienstverlening en gezondheidszorg & 11.200 & 5.450 & 16.625 \\
MBO Economie & 9.525 & 2.550 & 12.075 \\
Totaal & 32.100 & 17.175 & 49.275 \\
\hline
\end{tabular}

Bron: ROC's Gelderland (Bekostigingstellingen 2000 en 2001, CFI)

Zoals bekend, zijn er in het MBO grote traditionele verschillen in de opleidingskeuze van mannen en vrouwen. Uit tabel 2.5 blijkt dat het grootste verschil zich voordoet bij MBO Techniek en MBO Dienstverlening en gezondheidszorg. Slechts $5 \%$ van de leerlingen van de technische opleidingen is vrouw. Bij opleidingen zoals $M B O$ Installatietechniek, MBO Werktuigbouw en mechanische techniek en MBO Elektrotechniek is het aantal vrouwen zelfs te verwaarlozen ( $1 \%$ of minder). Opleidingen als MBO Fijnmechanische techniek en laboratorium (45\%) en MBO Grafische techniek (25\%) zijn onder vrouwen daarentegen relatief populair. 
In de sector MBO Dienstverlening en gezondheidszorg zijn vrouwen met $79 \%$ ruim in de meerderheid. In opleidingen als MBO Dokters-, tandarts- en dierenartsassistent, MBO Apothekersassistent en MBO Uiterlijke verzorging is meer dan $95 \%$ van de leerlingen vrouw. In de opleidingen $M B O$ Horeca en $M B O$ Beweging en therapie zijn vrouwen echter met respectievelijk $40 \%$ en $32 \%$ in de minderheid.

In de sector MBO Landbouw en natuurlijke omgeving houden mannen en vrouwen veel meer in evenwicht. Datzelfde geldt voor de sector MBO Economie. Binnen deze sector zijn de verschillen echter groot. Zo is meer dan $80 \%$ van de leerlingen van de opleidingen MBO Secretariaat en MBO Toerisme en recreatie vrouw, terwijl maar $42 \%$ van de leerlingen van de opleiding MBO Administratie en logistiek van het vrouwelijk geslacht is.

In het $\mathrm{VMBO}$ zijn in de sector $\mathrm{VMBO}$ Zorg en welzijn de vrouwen in de meerderheid (78\%), terwijl in de sectoren VMBO Landbouw en natuurlijke omgeving en VMBO Economie mannen en vrouwen elkaar min of meer in evenwicht houden. Dit komt overeen met het beeld zoals we dat bij het MBO hebben gezien. In de sector VMBO Techniek is het beeld echter afwijkend. Maar liefst $38 \%$ van de technisch opgeleiden in het VMBO is vrouw.

Tabel 2.5

Aantal (bekostigde) leerlingen in het VMBO en MBO in Gelderland naar geslacht en onderwijssector, kalenderjaar 2001

\begin{tabular}{|c|c|c|c|}
\hline \multirow[b]{2}{*}{ Opleidingssector } & \multicolumn{3}{|c|}{ Aantal leerlingen } \\
\hline & Mannen & Vrouwen & Totaal \\
\hline VMBO Theorie & 54.600 & 48.425 & 103.025 \\
\hline VMBO Landbouw en natuurlijke omgeving & 1.525 & 1.325 & 2.850 \\
\hline VMBO Techniek & 7.300 & 4.475 & 11.775 \\
\hline VMBO Zorg en welzijn & 1650 & 5.900 & 7.550 \\
\hline VMBO Economie & 5.275 & 6.700 & 11.975 \\
\hline VMBO Totaal & 70.775 & 67.850 & 138.625 \\
\hline HAVO/VWO & 32.300 & 39.850 & 71.150 \\
\hline MBO Landbouw en natuurlijke omgeving & 1.700 & 1.650 & 3.350 \\
\hline MBO Techniek & 15.950 & 850 & 16.800 \\
\hline MBO Dienstverlening en gezondheidszorg & 3.500 & 13.125 & 16.625 \\
\hline MBO Economie & 5.425 & 6.650 & 12.075 \\
\hline Totaal & 26.500 & 22.775 & 49.275 \\
\hline
\end{tabular}

\subsection{De arbeidsmarktpositie van MBO-schoolverlaters}

In deze paragraaf zal een beeld worden geschetst van de actuele arbeidsmarktpositie van MBO-schoolverlaters. We beperken ons hierbij tot schoolverlaters van de initiële opleidingen in het MBO van de ROC's en AOC's in Gelderland. We geven in deze paragraaf een overzicht van de ontwikkeling van de arbeidsmarkt- 
positie van de schoolverlaters in de periode 1996-2001. ${ }^{11}$ Hierbij kijken we zowel naar de situatie op de arbeidsmarkt (het werkloosheidspercentage en de beloning), als ook naar de verborgen aansluitingsproblemen: het moeten accepteren van werk beneden het eigen niveau of buiten het eigen vakgebied, vaker een tijdelijke in plaats van een vaste aanstelling krijgen, of vaker genoegen moeten nemen met deeltijdwerk, terwijl men liever een fulltime betrekking zou willen hebben. De cijfers over de Gelderse schoolverlaters worden telkens vergeleken met de cijfers voor Nederland als geheel. Tevens zal telkens worden aangegeven in hoeverre het beeld voor bepaalde opleidingssectoren afwijkt van de situatie voor het gehele MBO in Gelderland. $^{12}$

\section{Open discrepanties}

Aansluitingsproblemen op de arbeidsmarkt kunnen zich op verschillende manieren manifesteren. In deze paragraaf wordt de aandacht allereerst gericht op de (intrede)werkloosheid en het gemiddelde bruto maandloon onder MBO-schoolverlaters. Het werkloosheidspercentage en de beloning in een bepaald marktsegment geven een indicatie van de zogenaamde open discrepanties tussen vraag en aanbod op de arbeidsmarkt.

\section{Figuur 2.1}

Werkloosheid in procenten onder MBO-schoolverlaters, Gelderland en Nederland, 1996-2001

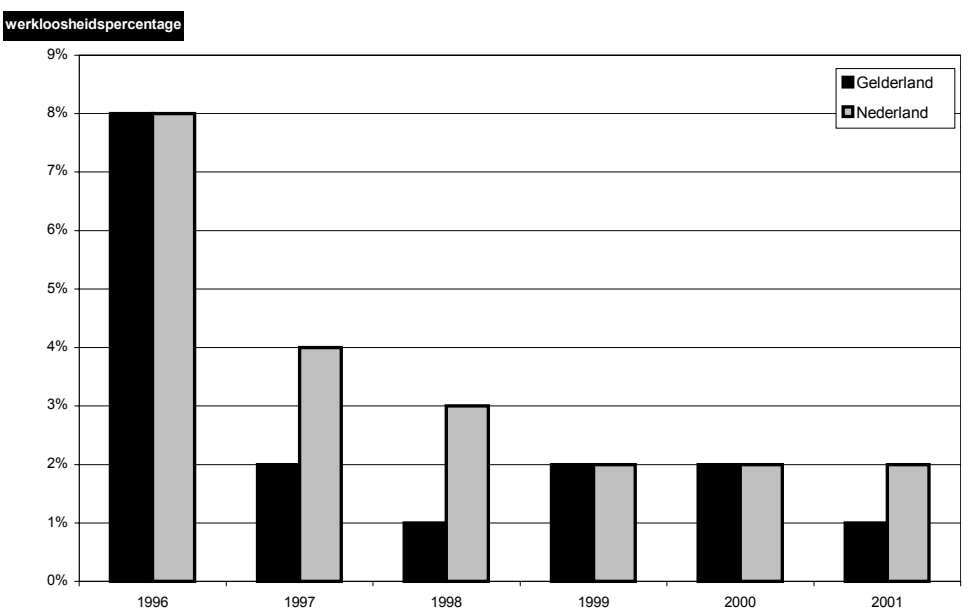

11. De cijfers in deze paragraaf zijn afkomstig uit het Schoolverlaters Informatie Systeem (SIS) van het ROA. Ze dienen met enige voorzichtigheid betracht te worden, daar niet alle Gelderse ROC's gedurende alle jaren aan de enquêtes hebben deelgenomen.

12. De figuren in het vervolg van deze paragraaf hebben betrekking op het totale MBO. Voor een overzicht van de informatie voor het jaar 2001 naar onderliggende opleidingssector, zie: tabellen 3.5 tot en met 3.11 van de Statistische Bijlage. 
De werkloosheid is de meest in het oog springende indicator voor de arbeidsmarktpositie. In figuur 2.1 wordt een overzicht gegeven van de ontwikkeling in het aantal werkloze schoolverlaters als percentage van het totaal aantal MBO-schoolverlaters gedurende de afgelopen zes jaar. De cijfers illustreren de grote krapte op de arbeidsmarkt in de afgelopen jaren. Zowel in Gelderland als in de rest van het land is de werkloosheid sinds 1999 erg laag. Werkloosheidspercentages van 1 of $2 \%$ kunnen grotendeels gezien worden als onvermijdbare frictiewerkloosheid (zie Verklarende woordenlijst). De verschillen tussen de opleidingssectoren zijn gering. Met name in Gelderland zijn ook de werkloosheidspercentages voor MBO-schoolverlaters binnen de opleidingssectoren niet hoger $2 \%$.

Figuur 2.2

Intredewerkloosheid (in procenten) onder MBO-schoolverlaters, Gelderland en Nederland, 1996-2001

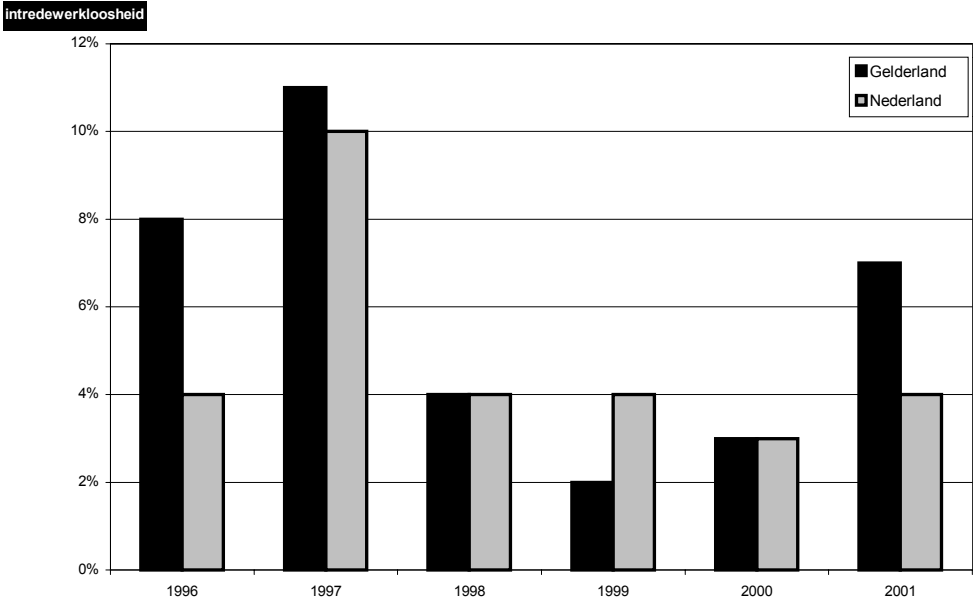

Daarnaast is het zinvol te kijken naar de wijze waarop de starter zijn weg vindt op de arbeidsmarkt. Is er sprake van een moeizame start? Of is de overgang van school naar werk gladjes verlopen? Een indicator voor deze startersproblematiek is de intredewerkloosheid. Figuur 2.2 laat het percentage schoolverlaters zien dat na het verlaten van de opleiding ten minste 4 maanden op zoek is geweest naar een baan. Uit de figuur blijkt dat de intredewerkloosheid in Gelderland de laatste jaren weer toeneemt. In 2001 geeft $7 \%$ van de Gelderse MBO-schoolverlaters aan langer dan 4 maanden op zoek te zijn geweest naar de eerste baan. Dit is bijna twee keer zoveel als in de rest van het land. In Gelderland is met name de intredewerkloosheid bij schoolverlaters van $M B O$ Economie groot. Ondanks de stijging is het niveau van de intredewerkloosheid nog ver verwijderd nog van het niveau halverwege de jaren '90 toen meer dan $10 \%$ van de schoolverlaters er langer dan 4 maanden over deed een eerste baan te vinden. 
Figuur 2.3

Gemiddeld bruto maandloon (in euro's) onder MBO-schoolverlaters, Gelderland en Nederland, 1996-2001

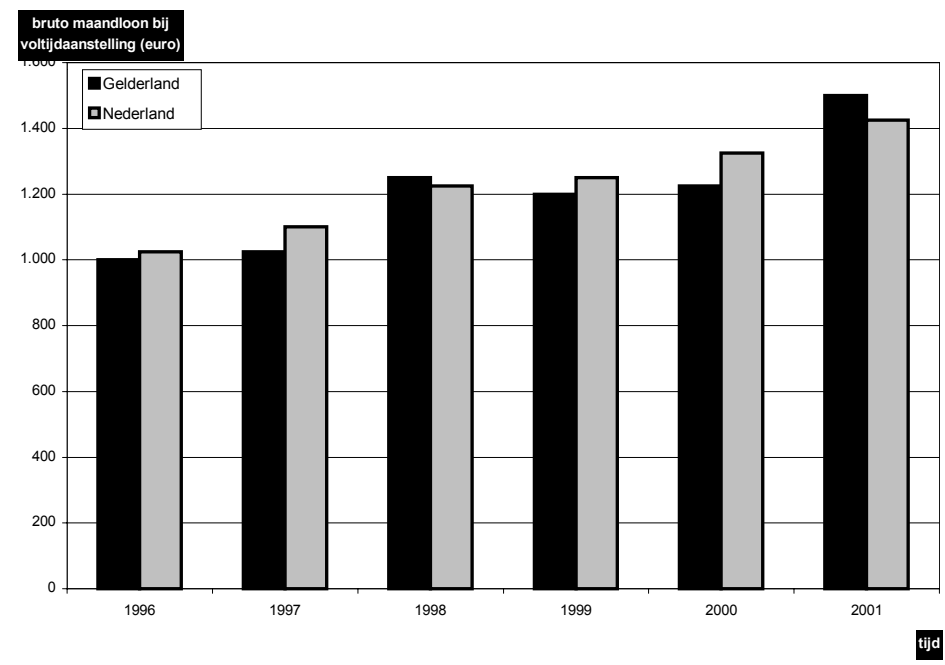

Een andere belangrijke indicator voor de arbeidsmarktpositie van opleidingen vormt de beloning. De beloning geeft immers een directe indicatie van de waarde van de verworven kwalificaties op de arbeidsmarkt. In figuur 2.3 wordt de bruto loonontwikkeling voor MBO-schoolverlaters beschreven. Het gaat hierbij om het bruto maandloon waar nodig gecorrigeerd voor het aantal gewerkte uren opdat het loon voor een voltijds aanstelling wordt verkregen. De figuur laat zien dat de beloning voor MBO-schoolverlaters, na een periode waarin de lonen min of meer stabiel waren, in 2001 sterk zijn gestegen in Gelderland. In 2000 verdiende de Gelderse MBOschoolverlaters ruim $€ 1.200$ per maand; in 2001 is de beloning gestegen tot maar liefst $€ 1.500$. Dit is een stijging van meer dan $20 \%$. Landelijk was er de laatste jaren sprake van een gestage groei. In 2001 groeiden de lonen landelijk met zo'n 8\%. Door de sterke stijging van de lonen in Gelderland, ligt het loonniveau in Gelderland voor het eerst sinds jaren hoger dan het niveau in de rest van het land. In Gelderland zijn in de sector MBO Techniek de lonen het hoogst. De MBO-schoolverlater uit deze sector verdient gemiddeld zo'n $€ 1.650$ per maand. Ook in de rest van het land verdienen de technisch opgeleiden het meest. In de sector MBO Dienstverlening en gezondheidszorg zijn de lonen het afgelopen jaar In Gelderland het meest gestegen. Ook dit is in de rest van het land ook het geval.

Al met al kan worden geconcludeerd dat de Gelderse arbeidsmarkt voor MBOschoolverlaters in 2001 nog steeds wordt gekenmerkt door een grote krapte. Het tekort aan schoolverlaters heeft ertoe geleid dat de werkloosheid erg laag is en de lonen sterk stijgen. De signalen van de krapte zijn in Gelderland zelfs sterker dan landelijk. Mede als gevolg hiervan is het gemiddeld loonpeil in Gelderland voor het eerst hoger dan landelijk. 


\section{Verborgen discrepanties}

Naast de open discrepanties kan er ook sprake zijn van verborgen discrepanties bij degenen die wel werk hebben gevonden. Van dergelijke aansluitingsproblemen is bijvoorbeeld sprake als schoolverlaters werk moeten accepteren beneden hun niveau of buiten hun vakgebied, vaker een tijdelijke in plaats van een vaste aanstelling krijgen, of vaker genoegen moeten nemen met deeltijdwerk, terwijl men liever een fulltime betrekking zou willen hebben.

De flexibilisering van de arbeidsmarkt was een aantal jaren geleden een hot item. Flexibilisering werd gezien als een belangrijk middel om de slagvaardigheid van bedrijven te bevorderen en de kansen van werknemers op de arbeidsmarkt te vergroten. Het tekort aan personeel van de laatste jaren heeft deze discussie wat naar de achtergrond gedrongen. Figuur 2.4 illustreert dit. De figuur laat zien hoeveel MBO-schoolverlaters anderhalf jaar na afstuderen werkzaam zijn met een flexibel arbeidscontract. Dit zijn banen via een uitzendbureau, als oproepkracht, of met een tijdelijke aanstelling zonder uitzicht op een vaste baan of met een aanstelling met een duur korter dan een jaar. De figuur laat zien dat het aandeel van flexibele arbeidskrachten in Gelderland de laatste jaren is gedaald van 47\% in 1996 naar 27\% in 2001. Landelijk is er zelfs sprake van een halvering van $44 \%$ tot $21 \%$. Overigens laat de figuur tevens zien dat de afname van de flexibele arbeidsmarkt voor MBOschoolverlaters, met name landelijk, de laatste drie jaar veel trager verloopt dan de jaren daarvoor. Blijkbaar is er, zelfs wanneer en sprake is van een groot tekort aan arbeidskrachten, behoefte aan tijdelijk personeel.

In Gelderland is met name de behoefte aan tijdelijk personeel met een opleiding in de sector MBO Dienstverlening en gezondheidszorg de afgelopen jaren gedaald. In 1996 was nog ongeveer de helft van de MBO-schoolverlaters uit deze sector als flexibele arbeidskracht werkzaam. In 2001 is dit nog maar 19\%. Van de schoolverlaters uit de andere sectoren heeft in Gelderland ruim 30\% een flexibel contract.

Het verband tussen de situatie op de arbeidsmarkt en het werken in deeltijd is niet eenduidig. Enerzijds geven werkgevers er in een situatie van hoogconjunctuur en arbeidsmarktkrapte de voorkeur aan dat mensen voltijds werken. Zolang werknemers ook graag voltijds willen werken, zal er een positief verband bestaan tussen de conjuncturele situatie en het percentage werknemers dat voltijds werkt. Anderzijds biedt een gunstige economische situatie werknemers de ruimte hun persoonlijke voorkeuren ten aanzien van bijvoorbeeld deeltijdwerk te realiseren. Dit zou met name kunnen gelden voor vrouwen met jonge kinderen, of voor schoolverlaters die graag nog wat meer vrije tijd willen hebben of een deeltijdopleiding willen volgen. Waar bij krapte op de arbeidsmarkt werkgevers de keuze hebben tussen het parttime of in het geheel niet opvullen van een openstaande vacature, zullen ook zij in veel gevallen aan de eerste optie de voorkeur geven. 
Figuur 2.4

Percentage MBO-schoolverlaters met een flexibele aanstelling, Gelderland en Nederland, 19962001

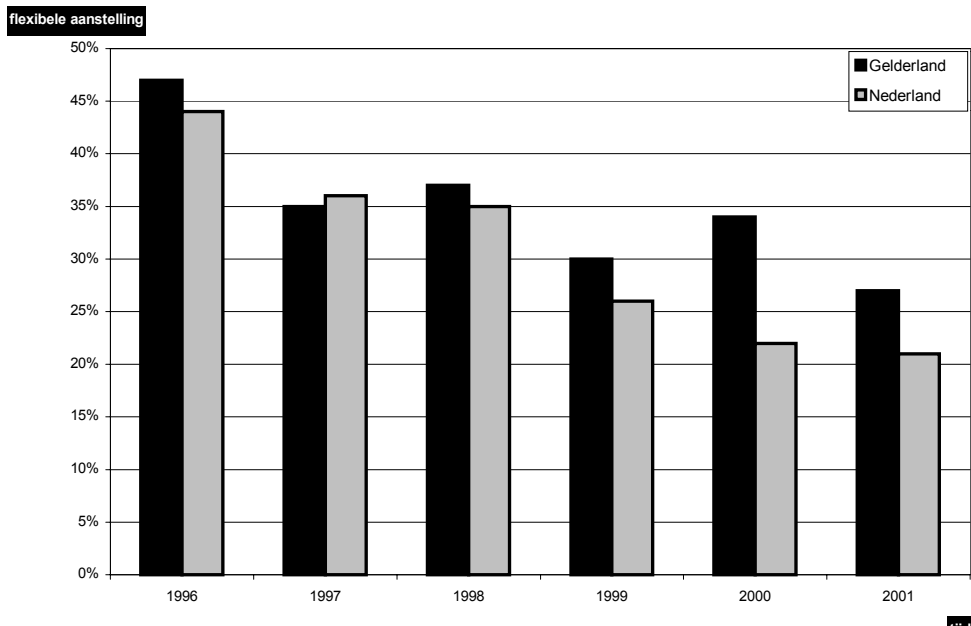

In figuur 2.5 wordt een beeld geschetst van het belang van deeltijdwerk. Het percentage MBO-schoolverlaters dat in deeltijd werkt lijkt in de loop der jaren iets toe te nemen. Landelijk is het percentage schoolverlaters dat minder dan 33 uur per week betaald werk verricht gestegen van $25 \%$ in 1996 tot $28 \%$ in 2001 . Het patroon in Gelderland is wat minder eenduidig. De cijfers laten wel zien dat het aantal deeltijders in Gelderland wat hoger is dan landelijk. Zo is in 2001 in Gelderland $32 \%$ van de MBO-schoolverlaters in deeltijd werkzaam. In hoeverre deze verschillen te maken hebben met het aanbod van deeltijdbanen bijvoorbeeld in relatie tot de conjuncturele ontwikkeling of met verschillen in de voorkeuren van Gelderse schoolverlaters en schoolverlaters in de rest van het land valt moeilijk te zeggen.

De verschillen tussen de opleidingssectoren zijn groot. Zowel in Gelderland als in de rest van het land is meer dan de helft van de schoolverlaters in de sector $M B O$ Dienstverlening en gezondheidszorg in deeltijd werkzaam. In Gelderland is dit zelfs $63 \%$. Voor de sector MBO Techniek is dit percentage lager dan 10. In Gelderland werkt $6 \%$ van de technische schoolverlaters minder dan 33 uur per week. De sectoren MBO Economie en MBO Landbouw en natuurlijke omgeving nemen een middenpositie in. Deze verschillen tussen de sectoren kunnen voor een belangrijk deel toegeschreven worden aan verschillen in het aantal vrouwelijke schoolverlaters. Dit wijst erop dat het werken in deeltijd vooral een kwestie is van de voorkeur van de werknemer en daarmee in veel mindere mate een gedwongen karakter heeft. 
Figuur 2.5

Percentage MBO-schoolverlaters dat in deeltijd werkt, Gelderland en Nederland, 1996-2001

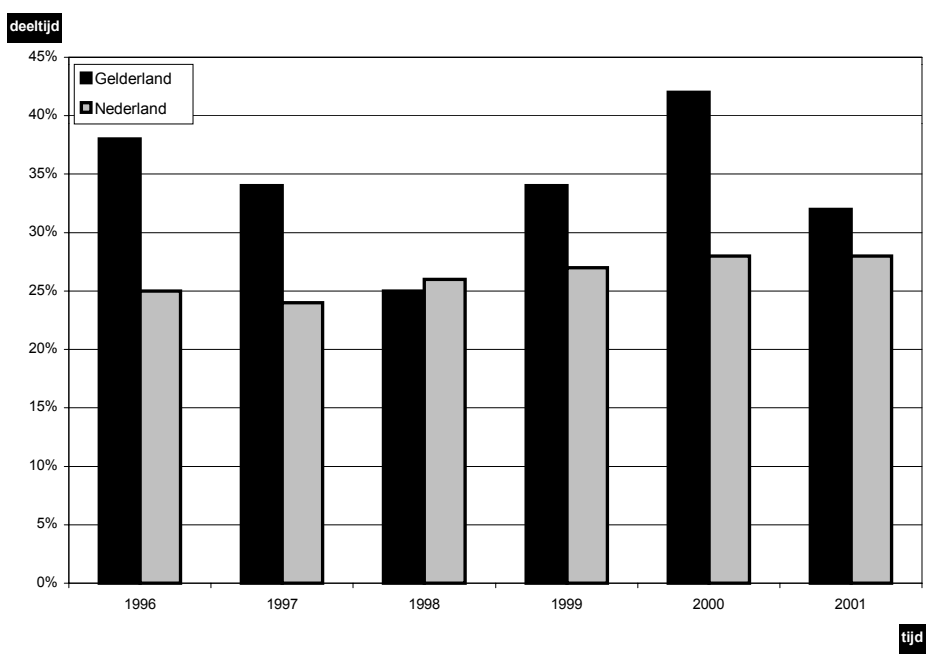

De mate waarin de in de opleiding verworven kwalificaties aansluiten op de door de werkgever vereiste kwalificaties vormt een belangrijke indicator voor de arbeidsmarktpositie van schoolverlaters en de kwaliteit van de aansluiting tussen onderwijs en arbeidsmarkt. Aansluitingsproblemen op de arbeidsmarkt voor schoolverlaters manifesteren zich bijvoorbeeld vaak in de noodzaak om een baan onder hun niveau te accepteren. Men spreekt dan wel van een onderbenutting van iemands kwalificaties. Figuur 2.6 laat zien dat onderbenutting een niet te onderschatten fenomeen vormt op zowel de Gelderse als de landelijke arbeidsmarkt voor MBO-schoolverlaters. Hoewel de percentages sterk wisselen van jaar tot jaar, blijkt dat zeker meer dan $30 \%$ van de MBO-schoolverlaters onder zijn of haar niveau werkzaam te zijn. In 2001 is in Gelderland 34\% van de schoolverlaters onder MBO-niveau werkzaam; landelijk is dit met $41 \%$ wat hoger.

De verschillen tussen de opleidingssectoren zijn aanzienlijk. In de sector $M B O$ Dienstverlening en gezondheidszorg is het percentage onderbenutting zowel in Gelderland als in de rest van het land lager dan gemiddeld. In Gelderland is $28 \%$ van de schoolverlaters in de sector MBO Dienstverlening en gezondheidszorg werkzaam onder zijn of haar niveau. Dit is, opvallend genoeg, iets meer dan landelijk. Schoolverlaters in de sectoren MBO Landbouw en natuurlijke omgeving en MBO Economie werken relatief vaak onder hun niveau. In Gelderland is dit respectievelijk 46 en 43 procent. 
Figuur 2.6

Onderbenutting onder MBO-schoolverlaters, Gelderland en Nederland, 1996-2001

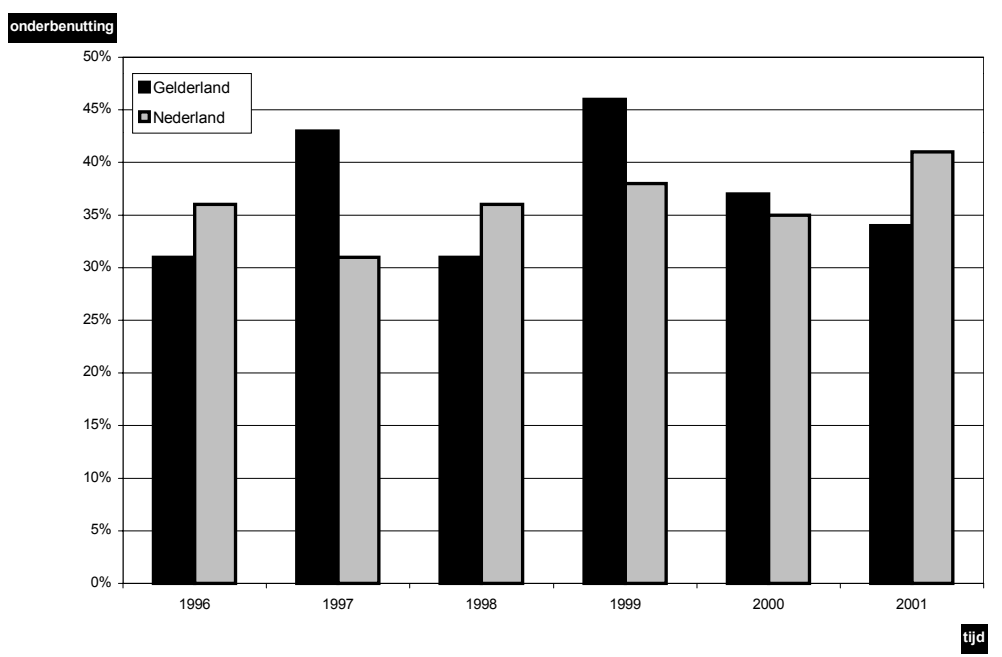

De tweede dimensie van de aansluitingsproblematiek tussen opleiding en beroepspraktijk wordt gevormd door de vraag in hoeverre de baan aans/uit bij de opleidingsrichting. Figuur 2.7 laat zien dat in Gelderland 26\% van de MBO-schoolverlaters emplooi heeft gevonden in een baan die minder goed aansluit bij de gevolgde opleidingsrichting. In de rest van het land is dit met $31 \%$ wat hoger. Dit percentage is de laatste jaren landelijk min of meer constant. In Gelderland is er daarentegen sprake van een aanzienlijke daling. In 1999 was nog 43\% van de Gelderse schoolverlaters buiten zijn of haar eigen richting werkzaam. Ook hier zijn er tussen de sectoren aanzienlijke verschillen. Zo is in Gelderland slechts $16 \%$ van de schoolverlaters in de sector MBO Dienstverlening en gezondheidszorg buiten zijn of haar eigen vakrichting werkzaam. Het sterk beroepsspecifieke karakter van de opleidingen in de gezondheidszorg zal hieraan mogelijk mede ten grondslag liggen. Met name voor de sectoren MBO Landbouw en natuurlijke omgeving en MBO Economie is het percentage schoolverlaters dat buiten de eigen vakrichting werkt relatief hoog. In Gelderland is dit respectievelijk 50 en 38 procent. Hiermee vertonen de verschillen tussen de sectoren min of meer hetzelfde beeld als de verschillen ten aanzien van de onderbenutting. Met andere woorden: hoe hoger het percentage schoolverlaters dat beneden zijn of haar niveau werkt, hoe hoger het percentage dat buiten de eigen vakrichting emplooi heeft gevonden. Bij de opleidingen op niveau 1 (assistentenopleiding) en 2 (basisberoepsopleiding) betekenen hoge percentages onderbenutting en een minder goede aansluiting naar richting veelal dat de schoolverlaters terechtkomen op de zogenaamde 'secundaire arbeidsmarkt' in banen waarvoor nauwelijks of geen scholing vereist is. Bij de opleidingen op niveau 3 (vakopleiding) en 4 (middenkader-/specialistenopleiding) kan het juist betkenen dat de zij breed inzetbaar zijn en vanuit een wat mindere startpositie mogelijk toch een goed carrièreperspectief hebben. 
Figuur 2.7

Percentage MBO-schoolverlaters dat buiten de eigen vakrichting werkzaam is, Gelderland en Nederland, 1996-2001

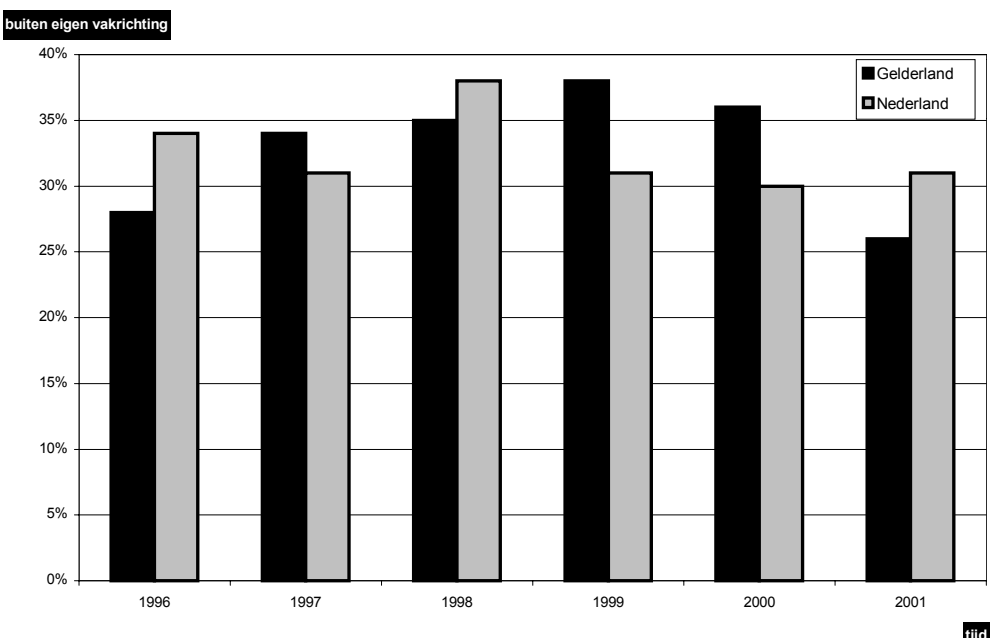




\section{De Gelderse arbeidsmarkt op de korte en de middellange termijn}

De sectorale werkgelegenheidsgroei op de korte termijn (2003) verschilt duidelijk van die op de middellange termijn (tot 2006). De bedrijfssectoren Voeding en Chemie gaan van krimp naar groei, en de bedrijfssector Bank- en verzekeringswezen slaat om van groei naar krimp. Voor de Kwartaire diensten, waartoe ook de gezondheidszorg wordt gerekend, wordt de werkgelegenheidsgroei op de middellange termijn vrijwel geheel in 2003 gerealiseerd. Omgekeerd geeft Bouw en onroerend goed op de middellange termijn een aanmerkelijk sterkere groei te zien dan op de korte termijn.

De vooruitzichten met betrekking tot de uitbreidingsvraag zijn in Gelderland ten opzichte van Nederland gunstiger voor de Technische en industrieberoepen, en de Informaticaberoepen, en ongunstiger voor de Pedagogische beroepen en de Openbare orde- en veiligheidsberoepen. Verder is er wat betreft de uitbreidingsvraag in Gelderland een tweedeling op de arbeidsmarkt naar opleidingsniveau zichtbaar, met ongunstige verwachtingen voor de werkgelegenheid van de lager geschoolden. Weliswaar zijn er op de middellange termijn minder opleidingssectoren met een krimpende werkgelegenheid dan op de korte termijn, maar wanneer er sprake is van krimp is het zonder uitzondering bij de opleidingssectoren op het lagere niveau.

Op de middellange termijn ziet het beeld voor de vervangingsvraag er voor Gelderland min of meer hetzelfde uit als op de korte termijn. De vervangingsvraag is meestal over de tijd genomen vrij stabiel. Door het belang van de geleidelijke ontwikkelingen in de demografie voor de vervangingsvraag is deze in ieder geval veel minder variabel dan de uitbreidingsvraag. Zowel op de korte als op de middellange termijn is er in Gelderland sprake van een hoge vervangingsvraag voor de Agrarische beroepen, de Pedagogische beroepen en de Openbare orde- en veiligheidsberoepen. Dat komt voor een belangrijke deel door het vergrijsde personeelsbestand in deze beroepsklassen. Omgekeerd valt de lage vervangingsvraag bij de Informaticaberoepen toe te schrijven aan het uitgesproken jonge personeelsbestand.

Uitgesproken hoge percentages vervangingsvraag zien we bij de opleidingssectoren Basisonderwijs, VMBO landbouw en HAVONWO. Mede als gevolg van het gebrek aan carrièreperspectief gaan veel werkenden met een dergelijke algemene opleidingsachtergrond op den duur aan een postinitiële opleiding deelnemen. De vervangingsvraag ten gevolge van de doorleerders vormt voor deze opleidingen dus een erg belangrijk deel van de totale vervangingsvraag. Daarnaast keren met name veel laaggeschoolde werkenden op den duur de arbeidsmarkt de rug toe.

Zowel op de korte als de middellange termijn is de arbeidsmarktinstroom van schoolverlaters van VMBO Landbouw en natuurlijke omgeving, VMBO Economie en 
HAVO/VWO erg hoog. Voor de eerste twee opleidingssectoren is de arbeidsmarktinstroom van schoolverlaters aanzienlijk groter dan landelijk.

\subsection{Inleiding}

In dit hoofdstuk wordt nader ingegaan op de verwachte vraag- en aanbodontwikkelingen op de Gelderse arbeidsmarkt op de korte en middellange termijn. In paragraaf 3.2 komt eerst de verwachte uitbreidingsvraag naar sector, beroep en opleiding aan de orde. In paragraaf 3.3 wordt de vervangingsvraag naar beroep en opleiding besproken. Tot slot volgt in paragraaf 3.4 de bespreking van de arbeidsmarktinstroom van schoolverlaters naar opleiding. In elke paragraaf worden zowel de hoofdlijnen per beroepsklasse en opleidingssector weergegeven, als de onderliggende opleidingstypen met de grootste of kleinste verwachte groei van de vraag naar of het aanbod van arbeid.

\subsection{Uitbreidingsvraag}

\section{Bedrijfssectoren}

Er kunnen twee componenten van vraag naar schoolverlaters kunnen worden onderscheiden, namelijk de uitbreidingsvraag ten gevolge van de verwachte werkgelegenheidsgroei en de vervangingsvraag veroorzaakt door (tijdelijke) uittrede van reeds werkenden. In deze paragraaf bespreken we om te beginnen de uitkomsten van de eerste vraagcomponent, de uitbreidingsvraag. Tabel 3.1 geeft voor de verschillende sectoren de uitbreidingsvraag op de korte en middellange termijn weer als percentage van de werkgelegenheid in het basisjaar. Deze cijfers worden voor de middellange termijn ook vergeleken met het landelijke beeld. ${ }^{13}$

Op de korte termijn groeit de Gelderse werkgelegenheid naar verwachting met een bescheiden $0,9 \%$. Dit komt overeen met ongeveer 8.000 werkenden. Hiermee blijft de verwachte groei achter bij het recente verleden (zie hoofdstuk 1). Dit totaalbeeld is een combinatie van een grote verscheidenheid aan verwachtingen, van een negatieve groei van meer dan 3\% voor Landbouw en visserij tot een positieve groei van 2,8\% voor Kwartaire diensten. Andere sectoren met krimp op de korte termijn zijn de industriesectoren Voeding, Chemie, Overige industrie en Energie. Met name deze conjunctuurgevoelige sectoren zullen naar verwachting hinder van de afgenomen economische groei ondervinden. De enige industriële sector die zich aan dit negatieve beeld onttrekt is de Metalektro, al is de groei met $0,2 \%$ zeer gering.

De tabel laat tevens duidelijk zien dat de groeiverwachtingen op de korte termijn verschillen van die op de middellange termijn. Voor drie sectoren geldt een zichtbare omslag. Voeding en Chemie gaan van krimp naar groei, en Bank- en verzekeringswezen slaat om van groei naar krimp. Voor andere sectoren is de groei op middellange termijn sterker of zwakker is dan op de korte termijn, zonder dat er een omslag is. Kwartaire diensten, waartoe ook de gezondheidszorg wordt gerekend, laat

13. ROA (2001), De arbeidsmarkt naar opleiding en beroep tot 2006, ROA-R-2001/8, Maastricht. 
naar verwachting op de korte termijn een groei zien van $2,8 \%$, welke op de middellange termijn daalt tot $5 \%$ (i.e. $0,9 \%$ gemiddeld per jaar). Omgekeerd geeft Bouw en onroerend goed juist op de middellange termijn een aanmerkelijk sterkere groei te zien dan op de korte termijn.

Tabel 3.1

Verwachte uitbreidingsvraag naar bedrijfssector op korte en middellange termijn, Gelderland

\begin{tabular}{lrr} 
Bedrijfssector & Gelderland & Gelderland \\
& 2003 & $\%$ \\
& $\%$ & \\
& & -12 \\
\hline & & 6 \\
Landbouw en visserij & $-3,2$ & 3 \\
Voeding & $-1,8$ & 8 \\
Chemie & $-1,0$ & -6 \\
Metaal en elektrotechniek & 0,2 & -6 \\
Overige industrie* & $-1,7$ & 14 \\
Energie* & $-1,7$ & 9 \\
Bouw en onroerend goed & 0,9 & 8 \\
Handel en reparatie & 0,9 & -6 \\
Transport en communicatie & 1,1 & 19 \\
Bank en verzekeringswezen & 0,4 & 5 \\
Horeca en zakelijke dienstverlening & 1,5 & 4 \\
Kwartaire diensten & 2,8 & 7 \\
Overheid en onderwijs & 1,4 & \\
Totaal & & \\
& &
\end{tabular}

* Bij het maken van de Gelderse prognoses zijn de bedrijfssectoren Overige industrie en Energie samengenomen, waardoor zij hier dezelfde percentages hebben.

Bron: $\mathrm{BEO} / \mathrm{CPB} / \mathrm{ROA}$

Naast de verwachte werkgelegenheidsgroei op de middellange termijn voor Gelderland, is in figuur 3.1 ook weergegeven de middellangetermijngroeiverwachting voor Nederland als geheel, zoals deze eerder gepresenteerd is in De arbeidsmarkt naar opleiding en beroep tot 2006. De totale middellangetermijngroei komt naar verwachting uit op $7 \%$ van de werkgelegenheid over de gehele periode. Dit is gelijk aan 58.000 werkenden en $1,4 \%$ groei gemiddeld per jaar.

In veel opzichten toont Gelderland zich als een gemiddelde provincie in figuur 3.1, met een paar uitzonderingen. De Metalektro heeft in Gelderland gunstigere vooruitzichten dan in Nederland. In mindere mate geldt dit ook voor Bouw en onroerend goed en Transport en communicatie. Omgekeerd geeft de sector Energie een werkgelegenheidskrimp te zien voor Gelderland, terwijl voor Nederland als geheel groei wordt verwacht (zie echter kanttekening bij tabel 3.1). 
Figuur 3.1

Verwachte uitbreidingsvraag naar bedrijfssector, 2001-2006, Gelderland en Nederland

bedrijfssector

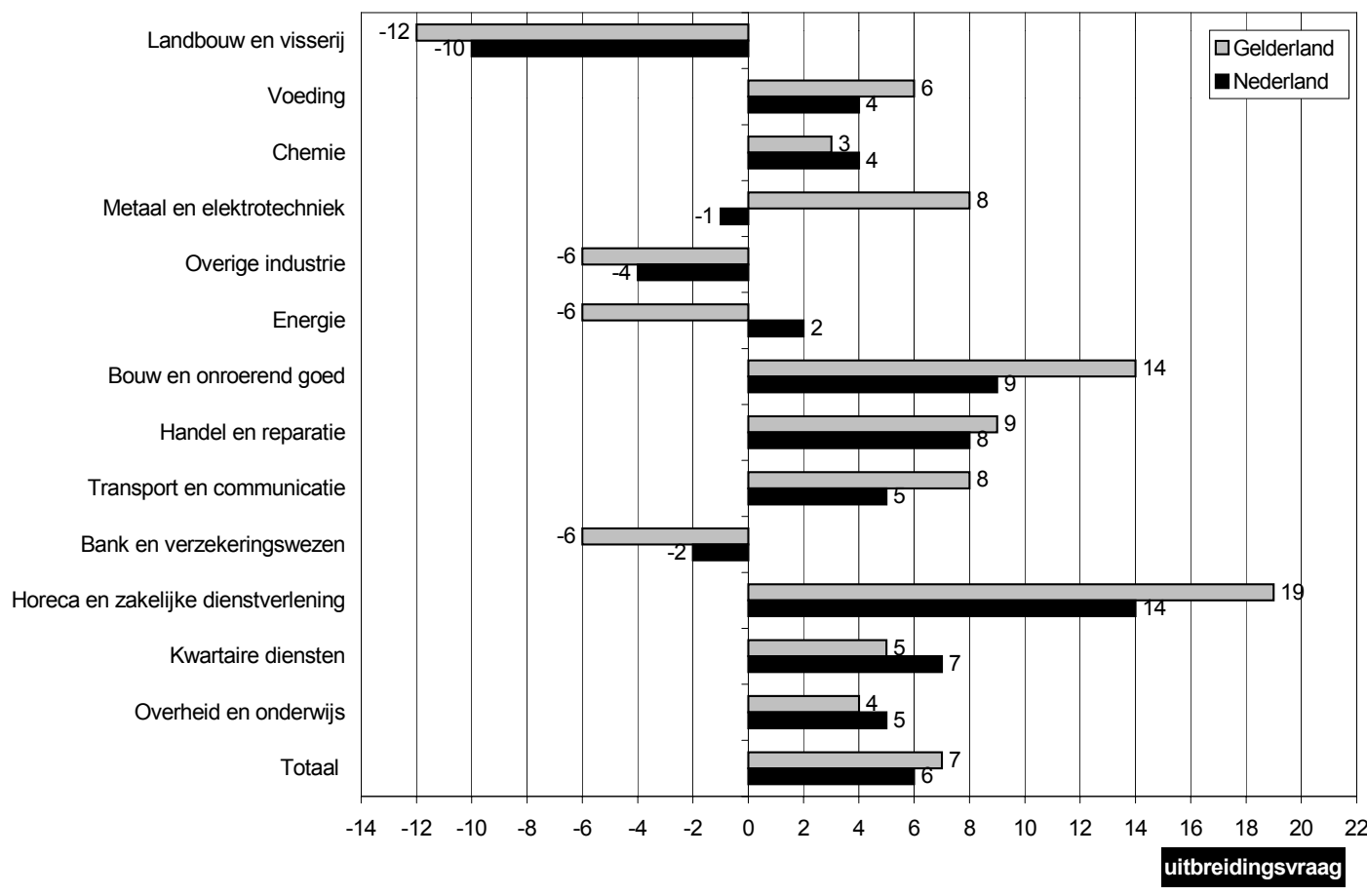

Bron: $\mathrm{BEO} / \mathrm{CPB} / \mathrm{ROA}$

\section{Beroepsklassen}

De verwachte groei of krimp van de werkgelegenheid naar bedrijfssector heeft gevolgen voor de werkgelegenheid naar beroep. In tabel 3.2 is de uitbreidingsvraag naar beroepsklasse weergegeven.

Op de korte termijn vertonen drie beroepsklassen in Gelderland de grootste relatieve groei. De Sociaal-culturele beroepen, de Informaticaberoepen en de Medische en paramedische beroepen groeien naar verwachting zeer sterk op de korte termijn. De werkgelegenheid in deze beroepsklassen neemt toe met meer dan 2,5\%. Met ongeveer 3.100 arbeidsplaatsen zijn deze beroepsklassen daarmee verantwoordelijk voor meer dan eenderde van de werkgelegenheidsgroei op de korte termijn.

De Economisch-administratieve beroepen groeien met 1,5\% min of meer gemiddeld, maar omdat dit een grote beroepsklasse is, vormt de verwachte werkgelegenheidsgroei van 3.700 arbeidsplaatsen toch bijna de helft van de totale uitbreidingsvraag. 
Negatieve uitschieters op de korte termijn zijn de beroepsklassen Agrarische beroepen en de Openbare orde- en veiligheidsberoepen, waarvoor bij de laatste opgemerkt moet worden dat het een relatief kleine beroepsklasse is, waardoor deze erg gevoelig voor kleine veranderingen.

Opvallend is dat de negatieve groeiverwachtingen van de industriële bedrijfssectoren (Voeding, Chemie, Overige industrie en Energie) zich niet vertalen in een krimp voor de Technische en industrieberoepen. Dit kan worden verklaard door twee factoren. Ten eerste, de positieve groei van twee andere industriële sectoren, Bouw en onroerend goed en de Metalektro. Ten tweede, de mogelijkheid dat de krimp in de industriële bedrijfssectoren veroorzaakt wordt door de afname van de werkgelegenheid in niet-technische of niet-industrieberoepen. Vooral ook in het licht van 'outsourcing', i.e. het afstoten van werkzaamheden van dienstverlenende aard door industriële bedrijven, kan dit van belang zijn.

Tabel 3.2

Verwachte uitbreidingsvraag naar beroepsklasse op korte en middellange termijn, Gelderland

\begin{tabular}{|c|c|c|}
\hline Beroepsklasse & $\begin{array}{r}\text { Gelderland } \\
2003 \\
\%\end{array}$ & $\begin{array}{r}\text { Gelderland } \\
2001-2006 \\
\%\end{array}$ \\
\hline Pedagogische beroepen & 0,9 & 1 \\
\hline Culturele beroepen & 1,0 & 5 \\
\hline Agrarische beroepen & $-1,9$ & -6 \\
\hline Technische en industrieberoepen & 0,3 & 3 \\
\hline Transportberoepen & 0,5 & 4 \\
\hline Medische en paramedische beroepen & 2,6 & 2 \\
\hline Economisch-administratieve beroepen & 1,5 & 12 \\
\hline Informaticaberoepen & 3,3 & 20 \\
\hline Sociaal-culturele beroepen & 3,5 & 18 \\
\hline Verzorgende en dienstverlenende beroepen & 0,9 & 3 \\
\hline Openbare orde- en veiligheidsberoepen & $-5,7$ & -3 \\
\hline Totaal & 0,9 & 6 \\
\hline
\end{tabular}

Bron: BEO/CPB/ROA

Figuur 3.2 toont dat voor de middellange termijn Gelderland niet heel veel afwijkt van de rest van Nederland. De vooruitzichten zijn in Gelderland gunstiger voor de Technische en industrieberoepen, de Informaticaberoepen, en ongunstiger voor de Pedagogische beroepen en de Openbare orde- en veiligheidsberoepen.

Aangezien de vooruitzichten voor een beroepsklasse niet noodzakelijkerwijs hoeven te gelden voor alle onderliggende beroepsgroepen, zijn in het volgende kader de meest opvallende uitkomsten op beroepsgroepniveau weergegeven. ${ }^{14}$ De uitschieters met voor Gelderland een relatief hoge of lage uitbreidingsvraag, zoals deze zijn weergegeven in het volgende kader, zijn vrij divers (uit verschillende

14. Voor het complete overzicht van korte- en middellangetermijnprognoses op dit lagere aggregatieniveau wordt verwezen naar de bij dit rapport verschenen Statistische Bijlage. 
klassen afkomstig). Alleen de beroepsgroepen met op de middellange termijn een relatief hoge uitbreidingsvraag passen nog enigszins bij elkaar. Met uitzondering van productieplanners en informatici zijn het namelijk allemaal Economisch-administratieve beroepen.

Figuur 3.2

Verwachte uitbreidingsvraag naar beroepsklasse, 2001-2006, Gelderland en Nederland

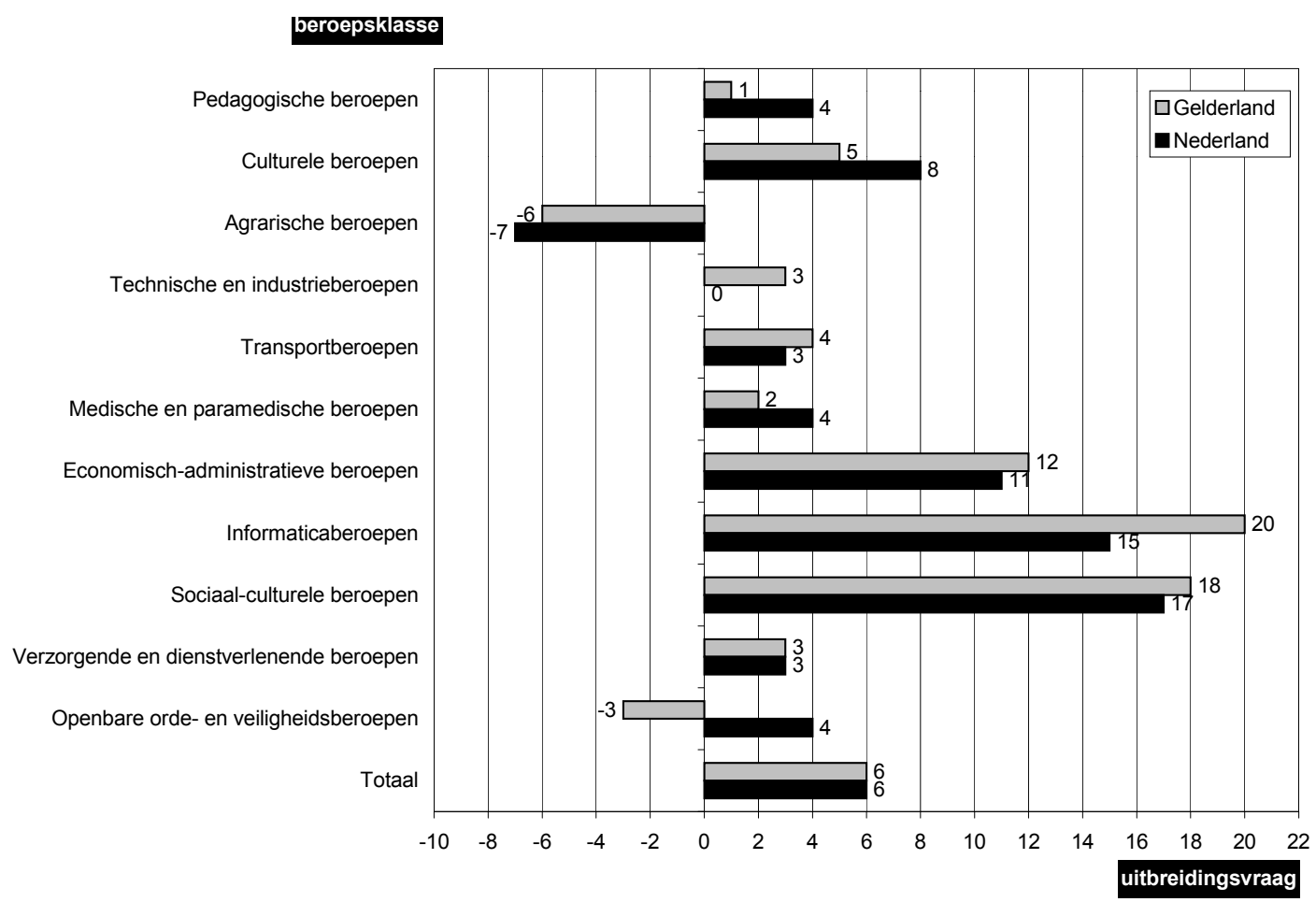

Bron: BEO/CPB/ROA 


\section{KORTE TERMIJN:}

Beroepsgroepen met een relatief hoge uitbreidingsvraag in Gelderland:

- Confectie-arbeiders*

- Juridisch en fiscaal medewerkers

- Weg- en waterbouwkundige vakkrachten

- Elektromonteurs

- Docenten exacte, medische en verzorgende vakken $\left(1^{\mathrm{e}}\right.$ graads)

- Hoofden technische dienst

Beroepsgroepen met een relatief lage uitbreidingsvraag in Gelderland:

- Bibliotheekassistenten

- Monteurs

- Weg- en waterbouwkundige arbeiders

- Kunstenaars

- Verpleeghulpen en leerling-verpleegkundigen

- Politieagenten, onderofficieren en beveiligingsemployés

\section{MIDDELLANGE TERMIJN:}

Beroepsgroepen met een relatief hoge uitbreidingsvraag in Gelderland:

- Accountants

- Productieplanners

- Leidinggevenden

- Informatici

- Organisatie-adviseurs

- Organisatie-deskundigen

Beroepsgroepen met een relatief lage uitbreidingsvraag in Gelderland:

- Weg- en waterbouwkundig arbeiders

- Receptionisten en administratieve employees

- Docenten talen en expressie

- Grafisch productiepersoneel

- Verpleeghulpen en leerling-verpleegkundigen

- Agrarische arbeiders

*) De confectie-arbeiders vormen in feite het grootste beroep binnen de CBS-klasse Lagere technische beroepen NEG (zie in deel 6 van de Statistische Bijlage het overzicht van beroepsgroepen volgens de SBC'92). Derhalve moet voorzichtig worden omgegaan met de interpretatie van de uitbreidingsvraag voor wat in dit rapport de beroepsgroep confectiearbeiders wordt genoemd.

\section{Opleidingssectoren}

De vraag naar werknemers die in een bepaald beroep kunnen worden ingezet kan ook worden voorgesteld als een vraag naar mensen met een bepaalde opleidings- 
achtergrond. Tabel 3.3 geeft een overzicht van de verwachte uitbreidingsvraag naar opleidingssector voor Gelderland en Nederland.

Met name op de korte termijn is een duidelijke tweedeling in de verwachte uitbreidingsvraag waarneembaar. Vooral de werkgelegenheid op de lagere opleidingsniveau's zal naar verwachting krimpen, terwijl de hogere opleidingsniveau's een positieve uitbreidingsvraag laten zien. De werkgelegenheid voor mensen met een HBO- of WO-opleidingsachtergrond neemt naar verwachting toe met rond 4.100 personen toe in Gelderland. De groei voor de opleidingssectoren MBO Techniek, MBO Economie en MBO Dienstverlening en gezondheidszorg bedraagt ongeveer 3.500 personen.

De werkgelegenheidskrimp voor Basisonderwijs en VMBO Landbouw en natuurlijke omgeving zet naar verwachting sterk door tussen 2003 en 2006. Andere opleidingssectoren lijken hun sterke groei op korte termijn niet te kunnen vasthouden. Dit geldt met name voor WO Medisch. De groei slaat naar verwachting om in een lichte krimp, hetgeen impliceert dat de groei vrijwel geheel in het eerste jaar wordt gerealiseerd.

Tabel 3.3

Verwachte uitbreidingsvraag naar opleidingssector op korte en middellange termijn, Gelderland

Opleidingssector Gelderland Gelderland

$2003 \quad 2001-2006$

\begin{tabular}{ll}
$\%$ & $\%$ \\
\hline
\end{tabular}

\begin{tabular}{lrr}
\hline & & \\
Basisonderwijs & $-0,1$ & -20 \\
VMBO Theorie & $-0,3$ & 1 \\
VMBO Landbouw en natuurlijke omgeving & $-1,0$ & -28 \\
VMBO Techniek & $-0,1$ & -9 \\
VMBO Economie & $-0,3$ & -14 \\
VMBO Verzorging & $-0,7$ & -8 \\
HAVO/VWO & 0,9 & 17 \\
MBO Landbouw en natuurlijke omgeving & $-1,1$ & 15 \\
MBO Techniek & 0,8 & 13 \\
MBO Economie & 1,1 & 9 \\
MBO Dienstverlening en gezondheidszorg & 1,6 & 7 \\
HBO Landbouw & 1,5 & 15 \\
HBO Techniek & 2,3 & 14 \\
HBO Economie & 2,3 & 22 \\
HBO Onderwijs en sociaal-cultureel & 1,2 & 7 \\
HBO Paramedisch & 2,8 & 21 \\
WO Landbouw en milieukunde & 1,6 & 14 \\
WO Techniek & 1,9 & 17 \\
WO Economie & 2,3 & 30 \\
WO Letteren en sociaal-cultureel & 2,4 & 22 \\
WO Medisch & 3,7 & 3 \\
Totaal & & 6 \\
& & \\
Bron: BEO/CPB/ROA & \\
\hline
\end{tabular}

Bron: BEO/CPB/ROA

De tweedeling met ongunstige verwachtingen voor de lagere opleidingssectoren blijft ook op de middellange termijn overeind. Weliswaar zijn er op de middellange termijn minder opleidingssectoren met een krimpende werkgelegenheid dan op de korte 
termijn, maar wanneer er sprake is van krimp is het ook nu zonder uitzondering bij de opleidingssectoren op het lagere niveau.

Over het algemeen geldt ook voor de opleidingssectoren dat de verwachtingen voor de uitbreidingsvraag op de middellange termijn in Gelderland het landelijke beeld volgen (zie figuur 3.3). Maar ook nu zijn er verschillen. Zo krimpt de werkgelegenheid van VMBO economie met maar liefst $14 \%$ in Gelderland terwijl er in Nederland sprake is van 'slechts' $6 \%$ werkgelegenheidskrimp.

Figuur 3.3

Verwachte uitbreidingsvraag naar opleidingssector, 2001-2006, Gelderland en Nederland

opleidingssector

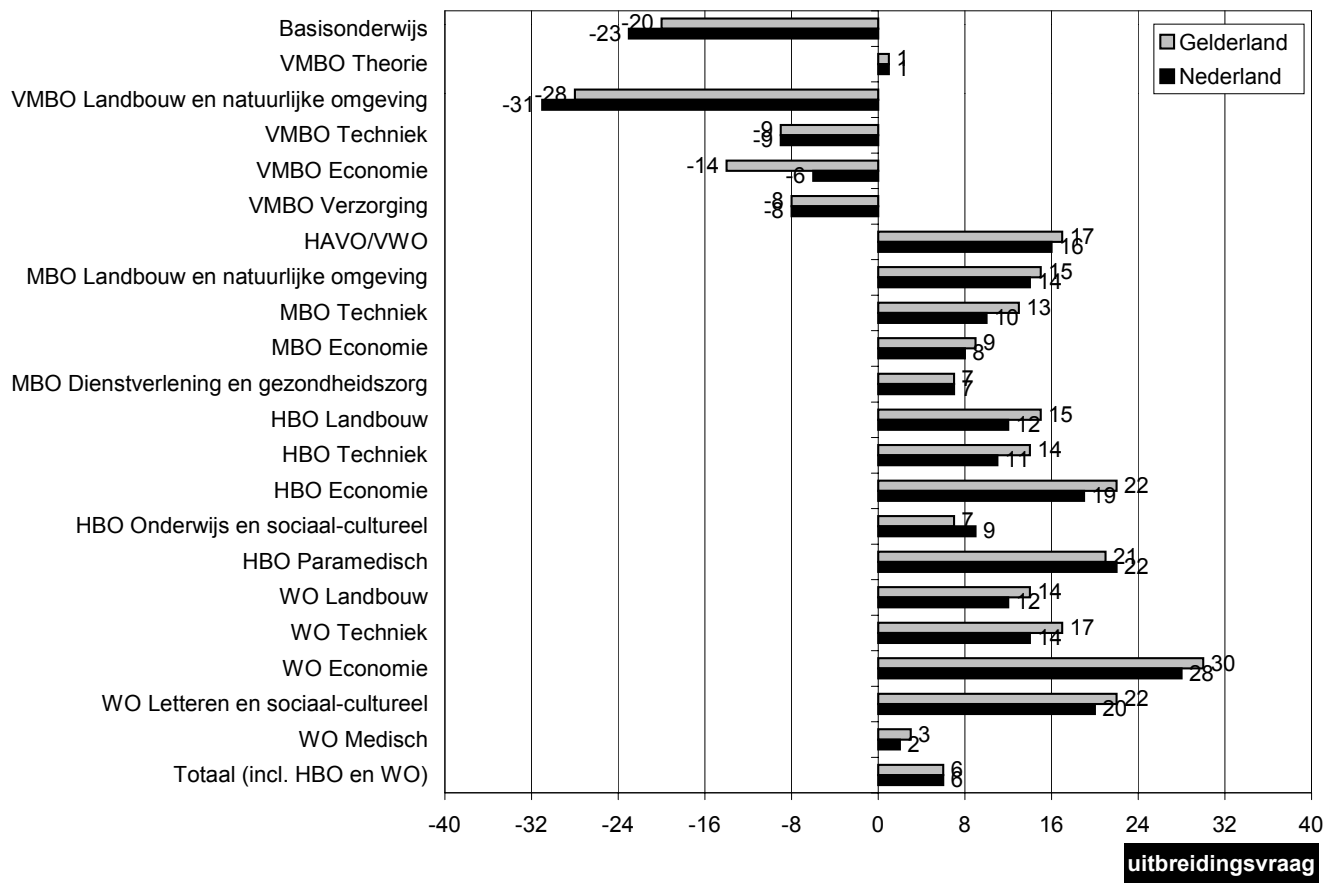

Bron: $\mathrm{BEO} / \mathrm{CPB} / \mathrm{ROA}$ 


\section{KORTE TERMIJN:}

Opleidingstypen met een relatief hoge uitbreidingsvraag in Gelderland:

- HBO laboratorium

- HBO maatschappelijk werk en hulpverlening

- HBO personeelswerk

- HBO verpleegkunde

- WO tandheelkunde

- WO (dier)geneeskunde

Opleidingstypen met een relatief lage uitbreidingsvraag in Gelderland:

- VMBO landbouw en natuurlijke omgeving

- VMBO verzorging

- VMBO bouwtechniek

- VMBO voeding, natuur en milieu

- VMBO administratie, handel en textiel

- MBO groene ruimte

\section{MIDDELLANGE TERMIJN:}

Opleidingstypen met een relatief hoge uitbreidingsvraag in Gelderland:

- HBO informatica

- HBO bedrijfskunde

- HBO (fysio)therapie

- WO econom(etr)ie

- HBO recht en bestuur

- WO bedrijfskunde

Opleidingstypen met een relatief lage uitbreidingsvraag in Gelderland:

- Basisonderwijs

- VMBO landbouw en natuurlijke omgeving

- VMBO motorvoertuigentechniek

- VMBO administratie, handel en textiel

- VMBO mechanische techniek

- VMBO vervoer

- MRO neld hank en helastinnen

In het kader staan opleidingstypen vermeld met een relatief hoge of lage verwachte uitbreidingsvraag op de korte of middellange termijn. Een lage uitbreidingsvraag komt ook hier met name voor bij opleidingstypen op VMBO-niveau en in de landbouw-, milieu- of technische richtingen. Een relatief hoge uitbreidingsvraag valt waar te nemen op vooral HBO- en WO-niveau, en dan met name in de (para)medische richting voor de uitbreidingsvraag op de korte termijn en de economische richting voor de uitbreidingsvraag op de middellange termijn. 


\subsection{Vervangingsvraag}

In deze paragraaf behandelen we de tweede vraagcomponent: de vervangingsvraag. De vervangingsvraag is de vraag naar arbeidskrachten welke voortvloeit uit het vertrek van werkenden. Deze werkenden kunnen om een breed scala aan redenen besluiten al dan niet tijdelijk de arbeidsmarkt te verlaten. Hierbij kan gedacht worden aan pensioen, VUT, arbeidsongeschiktheid, zorgtaken etc. Andere oorzaken van vervangingsvraag zijn baan-baanmobiliteit van werkenden tussen beroepsgroepen en cursussen of opleidingstrajecten welke leiden tot een verandering in de opleidingsachtergrond van werkenden. Tenzij er sprake is van een reductie van het aantal arbeidsplaatsen geldt dat een werkgever deze vertrekkende werknemers zal moeten vervangen. Hiermee genereert een vertrekkende werknemer dus vraag naar een vervanger.

\section{Beroepsklassen}

Tabel 3.4 geeft een overzicht van de verwachte vervangingsvraag per beroepsklasse voor Gelderland op de korte en de middellange termijn. Op de korte termijn is de vervangingsvraag in Gelderland gelijk aan ongeveer 28.000 arbeidsplaatsen. Dit aantal is equivalent aan $3,4 \%$ van het aantal werkenden.

Tabel 3.4

Verwachte vervangingsvraag naar beroepsklasse op korte en middellange termijn, Gelderland

\begin{tabular}{|c|c|c|}
\hline Beroepsklasse & $\begin{array}{r}\text { Gelderland } \\
2003 \\
\%\end{array}$ & $\begin{array}{r}\text { Gelderland } \\
2001-2006 \\
\%\end{array}$ \\
\hline Pedagogische beroepen & 4,5 & 23 \\
\hline Culturele beroepen & 3,7 & 18 \\
\hline Agrarische beroepen & 5,0 & 25 \\
\hline Technische en industrieberoepen & 3,8 & 19 \\
\hline Transportberoepen & 3,2 & 16 \\
\hline Medische en paramedische beroepen & 2,8 & 14 \\
\hline Economisch-administratieve beroepen & 3,3 & 16 \\
\hline Informaticaberoepen & 1,6 & 8 \\
\hline Sociaal-culturele beroepen & 2,7 & 14 \\
\hline Verzorgende en dienstverlenende beroepen & 3,0 & 15 \\
\hline Openbare orde- en veiligheidsberoepen & 4,5 & 22 \\
\hline Totaal & 3,4 & 17 \\
\hline
\end{tabular}

Bron: ROA

Gezien de oorzaken van arbeidsmarktuittrede is het duidelijk dat de vervangingsvraag voor een belangrijk deel wordt bepaald door de samenstelling van het personeelsbestand. ${ }^{15}$ De leeftijd- en geslachtsopbouw van de werkenden binnen de

15. Zie voor een beschouwing over de samenhang tussen de vervangingsvraag en de opbouw van het personeelsbestand ook hoofdstuk 5 van De arbeidsmarkt naar opleiding en beroep tot 2006 (ROA, 2001). Voorts wordt er in dat hoofdstuk ook ingegaan op de relatie tussen arbeidsomstandigheden en vervangingsvraag (zie ook hieronder). 
beroepsklasse zijn voor een belangrijk deel verantwoordelijk voor de verwachte uittrede van de arbeidsmarkt. Wanneer een beroepsklasse getypeerd wordt door een groot aandeel ouderen tegen de VUT- en pensioengerechtigde leeftijd, ligt het in de lijn der verwachting dat deze beroepsklasse binnenkort veel vervangingsvraag tegemoet kan zien.

Figuur 3.4

Verwachte vervangingsvraag naar beroepsklasse, 2001-2006, Gelderland en Nederland

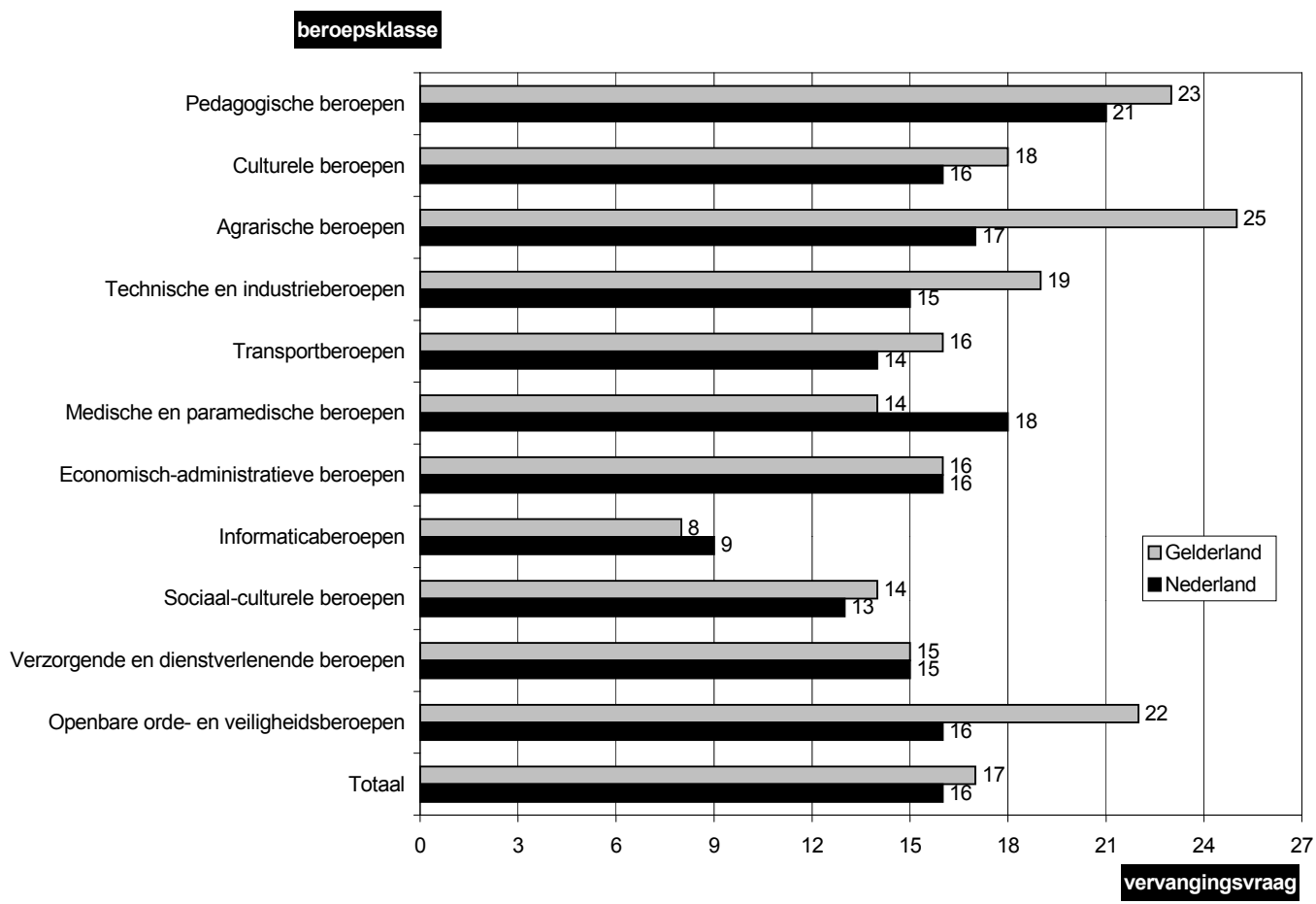

Bron: ROA

Op de korte termijn is er in Gelderland sprake van een hoge vervangingsvraag voor de Agrarische beroepen, de Pedagogische beroepen en de Openbare orde- en veiligheidsberoepen. Deze beroepsklassen kunnen, zowel landelijk als regionaal, worden getypeerd als beroepsklassen met veel oudere mannen onder het personeel. Omgekeerd valt de lage vervangingsvraag bij de Informaticaberoepen toe te schrijven aan het uitgesproken jonge personeelsbestand. Opvallend is de relatief lage vervangingsvraag bij de Medische en paramedische beroepen, want vanwege het grote aandeel van vrouwen in deze klasse zou tijdelijke uittrede vanwege huishoudelijke of zorgtaken relatief vaak voor kunnen komen. Niettemin blijft de vervangingsvraag voor 2003 met 2,8\% duidelijk achter bij het gemiddelde. 
Voor de Agrarische beroepen en de Pedagogische beroepen geldt verder dat de relatief hoge vervangingsvraag ook mede voortkomt uit de arbeidsomstandigheden. ${ }^{16}$ Lichamelijk of mentaal zware beroepen geven vaak hogere vervangingsvraag te zien. De lichamelijk zware beroepen (met veel tillen of krachtzetten), komen het meest voor bij de Agrarische beroepen, de Technische en industrieberoepen en de Medische en paramedische beroepen. Pedagogische beroepen en Economischadministratieve beroepen kunnen mentaal belastend worden genoemd.

\section{KORTE TERMIJN:}

Beroepsgroepen met een relatief hoge vervangingsvraag in Gelderland:

- Docenten talen en expressie

- Docenten landbouw en techniek $\left(2^{\mathrm{e}}\right.$ en $3^{\mathrm{e}}$ graads)

- Conciërges

- Agrarische bedrijfshoofden

- Docenten exacte, medische en verzorgende vakken $\left(1^{\mathrm{e}}\right.$ graads)

- Grafisch productiepersoneel

Beroepsgroepen met een relatief lage vervangingsvraag in Gelderland:

- Programmeurs

- Informatici

- Verpleeghulpen en leerling-verpleegkundigen

- Verzorgend personeel

- Systeemanalisten

- Juristen

\section{MIDDELLANGE TERMIJN:}

Beroepsgroepen met een relatief hoge vervangingsvraag in Gelderland:

- Docenten talen en expressie

- Docenten landbouw en techniek $\left(2^{\mathrm{e}}\right.$ en $3^{\mathrm{e}}$ graads)

- Conciërges

- Agrarische bedrijfshoofden

- Docenten exacte, medische en verzorgende vakken $\left(1^{\mathrm{e}}\right.$ graads)

- Grafisch productiepersoneel

Beroepsgroepen met een relatief lage vervangingsvraag in Gelderland:

- Programmeurs

- Informatici

- Verpleeghulpen en leerling-verpleegkundigen

- Verzorgend personeel

- Systeemanalisten

- Juristen

16. Zie voor uitgebreide informatie over de arbeidsomstandigheden en de belastende factoren in beroepen ROA (2002), Werkgelegenheid en scholing 2001, ROA-R-2002/7, Maastricht en de Statistische Bijlage van dat rapport. 
Op de middellange termijn ziet het beeld voor de vervangingsvraag er voor Gelderland min of meer hetzelfde uit als op de korte termijn. De vervangingsvraag is meestal over de tijd genomen vrij stabiel. Door het belang van de geleidelijke ontwikkelingen in de demografie voor de vervangingsvraag is deze in ieder geval veel minder variabel dan de uitbreidingsvraag.

De vervangingsvraag voor de middellange termijn in Gelderland lijkt op die in Nederland, met vier belangrijke uitzonderingen. De vervangingsvraag van de Agrarische beroepen, de Technische en industrieberoepen en de Openbare orde- en veiligheidsberoepen is in Gelderland groter dan in Nederland. De vervangingsvraag van de Medische en paramedische beroepen daarentegen is in Gelderland lager dan landelijk.

In het kader staan de verwachtingen voor de vervangingsvraag op het lagere aggregatieniveau weergegeven. De voorkomende beroepsgroepen zijn conform de resultaten van tabel 3.4, namelijk vooral een lage vervangingsvraag bij de Informaticaberoepen en een relatief hoge vervangingsvraag in de Pedagogische en Agrarische beroepen.

Tabel 3.5

Verwachte vervangingsvraag naar opleidingssector op korte en middellange termijn, Gelderland

Opleidingssector Gelderland
2003

Gelderland 2003
$\%$ 2001-2006

Basisonderwijs
VMBO Theorie
VMBO Landbouw en natuurlijke omgeving
VMBO Techniek
VMBO Economie
VMBO Verzorging
HAVO/NWO
MBO Landbouw en natuurlijke omgeving
MBO Techniek
MBO Economie
MBO Dienstverlening en gezondheidszorg
HBO Landbouw
HBO Techniek
HBO Economie
HBO Onderwijs en sociaal-cultureel
HBO Paramedisch
WO Landbouw en milieukunde
WO Techniek
WO Economie
WO Letteren en sociaal-cultureel
WO Medisch
Total

Totaal

$\begin{array}{ll}7,5 & 39 \\ 4,9 & 25 \\ 6,7 & 34 \\ 4,7 & 24 \\ 5,6 & 28 \\ 4,6 & 24 \\ 5,7 & 29 \\ 3,5 & 17 \\ 4,3 & 21 \\ 4,2 & 21 \\ 3,8 & 19 \\ 2,4 & 14 \\ 4,6 & 21 \\ 3,6 & 12 \\ 2,3 & 23 \\ 2,9 & 17 \\ 1,9 & 12 \\ 3,1 & 15 \\ 3,4 & 10 \\ 2,4 & 15 \\ 4,6 & 17 \\ & \\ 4,5 & 23\end{array}$

Bron: ROA

Tabel 3.5 geeft een overzicht van de vervangingsvraag naar opleidingssector in Gelderland. De vervangingsvraag is zowel op korte termijn als op middellange termijn 
hoger dan het totaal over de beroepen. Dit is het gevolg van het feit dat de vervangingsvraag naar opleiding impliciet rekening houdt met de effecten van doorleergedrag. Dat wil zeggen dat de vervangingsvraag naar opleiding wordt vergroot doordat werkenden door het volgen van een hogere of andere postinitiële vervolgopleiding een andere opleidingsachtergrond krijgen en daardoor in feite de uitstroom van werkenden voor de oorspronkelijke opleidingsachtergrond tot gevolg hebben.

Figuur 3.5

Verwachte vervangingsvraag naar opleidingssector, 2001-2006, Gelderland en Nederland

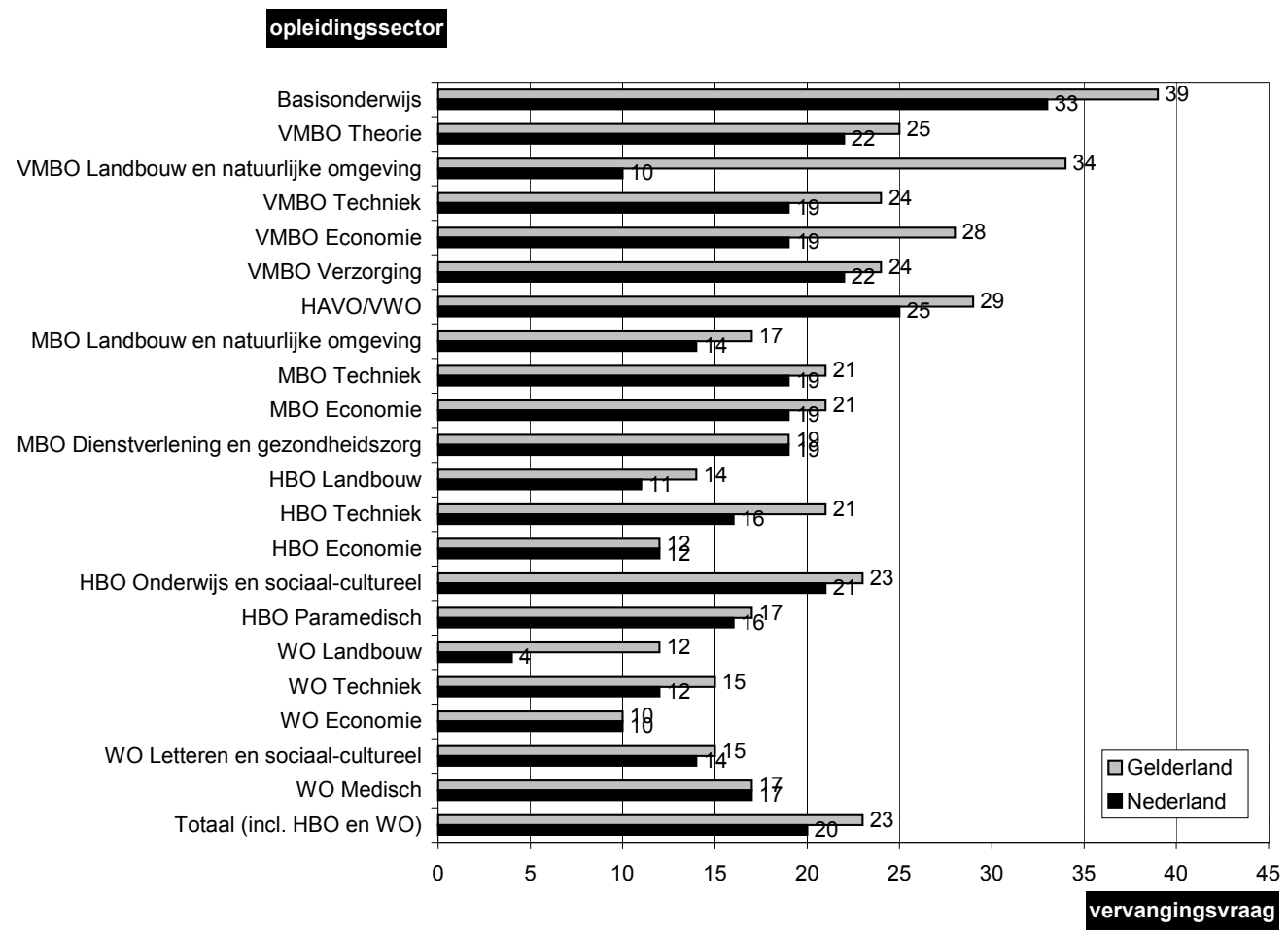

Bron: ROA

De totale vervangingsvraag voor de korte termijn inclusief doorleerders komt uit op $4,5 \%$, ofwel ongeveer 36.000 personen. Uitgesproken hoge percentages vervangingsvraag zien we bij de opleidingssectoren Basisonderwijs, VMBO Landbouw en natuurlijke omgeving en HAVONWO. Mede als gevolg van het gebrek aan carrièreperspectief gaan veel werkenden met een dergelijke algemene opleidingsachtergrond op den duur aan een postinitiële opleiding deelnemen. De vervangingsvraag ten gevolge van de doorleerders vormt voor deze opleidingen dus een erg belangrijk deel van de totale vervangingsvraag. Daarnaast komt het met name onder laaggeschoolden veel voor dat men de arbeidsmarkt de rug toekeert. Arbeidsongeschiktheid, maar ook de keuze voor het verrichten van huishoudelijke werk- 
zaamheden en zorgtaken binnen het gezin zijn belangrijke redenen voor nonparticipatie (zie hoofdstuk 6).

Net als bij de beroepsklassen verandert ook bij de opleidingssectoren de vervangingsvraag voor de middellange termijn niet veel ten opzichte van de vervangingsvraag voor de korte termijn. Opvallend is wel de afname van de vervangingsvraag tussen 2003 en 2006 voor HBO Landbouw, WO economie en WO Medisch.

Over het algemeen vertoont Gelderland een iets hogere vervangingsvraag dan landelijk, mede als gevolg van de iets oudere beroepsbevolking (zie hoofdstuk 1). Het totaalpercentage van $23 \%$ heeft betrekking op 184.000 werkenden. Vooral voor de opleidingsrichting landbouw op VMBO- en WO-niveau geldt dat de vervangingsvraag in Gelderland veel groter is dan in Nederland.

In het volgende kader is een aantal opleidingstypen met relatief veel of weinig vervangingsvraag in Gelderland weergegeven. We zien dezelfde uitschieters voor de korte termijn als voor de middellange termijn.

\section{KORTE TERMIJN:}

Opleidingstypen met een relatief hoge vervangingsvraag in Gelderland:

- Basisonderwijs

- VMBO administratie, handel en textiel

- MBO toerisme en recreatie

- HBO lerarenopleiding talen

- HBO lerarenopleiding economie en maatschappij

Opleidingstypen met een relatief lage vervangingsvraag in Gelderland:

- HBO commerciële economie

- WO letteren

- WO bedrijfskunde

- HBO bedrijfskunde

-WO landbouw en milieukunde

-WO rechten en bestuurskunde

\section{MIDDELLANGE TERMIJN:}

Opleidingstypen met een relatief hoge vervangingsvraag in Gelderland:

- Basisonderwijs

- VMBO administratie, handel en textiel

- MBO toerisme en recreatie

- HBO lerarenopleiding talen

- HBO lerarenopleiding economie en maatschappij

Opleidingstypen met een relatief lage vervangingsvraag in Gelderland:

- HBO commerciële economie

- WO letteren

- WO bedrijfskunde

- HBO bedrijfskunde

- WO landbouw en milieukunde

-WO rechten en bestuurskunde 


\subsection{Baanopeningen}

Wanneer we de prognoses van de uitbreidingsvraag en de vervangingsvraag sommeren, dan geeft dit een indicatie van de totale verwachte vraag: de baanopeningen voor nieuwkomers op de Gelderse arbeidsmarkt. Bij een krimpende werkgelegenheid bestaan de baanopeningen alleen uit de vervangingsvraag. Voor zover door het vertrek van werkenden dan vervangingsvraag ontstaat die wordt opgevuld door nieuwkomers, draagt dat bij aan het aantal baanopeningen.

\section{Beroepsklassen}

Tabel 3.6 geeft een overzicht van de totale vraag (als percentage van de werkgelegenheid) naar beroepsklasse voor Gelderland. De combinatie van uitbreidingsvraag en vervangingsvraag leidt op korte termijn tot veel baanopeningen bij de Culturele beroepen, de Pedagogische beroepen, de Sociaal-culturele beroepen en de Technische en industrieberoepen. Uitgesproken lage percentages baanopeningen zijn waarneembaar bij de Transportberoepen. Ook duidelijk beneden gemiddeld is de totale vraag bij de Openbare orde- en veiligheidsberoepen en de Verzorgende en dienstverlenende beroepen.

Tabel 3.6

Verwachte baanopeningen naar beroepsklasse in 2003 en in de periode 2001-2006

\begin{tabular}{lrr}
\hline Beroepsklasse & $\begin{array}{r}\text { Gelderland } \\
2003\end{array}$ & $\begin{array}{r}\text { Gelderland } \\
2001-2006 \\
\%\end{array}$ \\
& $\%$ & 26 \\
\hline & & 26 \\
Pedagogische beroepen & 7,7 & 27 \\
Culturele beroepen & 9,6 & 24 \\
Agrarische beroepen & 5,4 & 21 \\
Technische en industrieberoepen & 6,4 & 18 \\
Transportberoepen & 4,0 & 30 \\
Medische en paramedische beroepen & 5,8 & 28 \\
Economisch-administratieve beroepen & 5,7 & 32 \\
Informaticaberoepen & 4,9 & 20 \\
Sociaal-culturele beroepen & 6,7 & 24 \\
Verzorgende en dienstverlenende beroepen & 4,6 & 25 \\
Openbare orde- en veiligheidsberoepen & 4,5 & \\
Totaal & 5,7 & \\
\end{tabular}

Bron: ROA

Dit beeld zet zich niet voort op de middellange termijn; zo neemt de hoge vraag op de korte termijn voor de Culturele beroepen en de Pedagogische beroepen af tot $26 \%$ voor de middellange termijn, wat min of meer gemiddeld is. Voor de periode 2001-2006 zijn het vooral de Sociaal-culturele beroepen, de Economischadministratieve beroepen en de Informaticaberoepen met hoge percentages baanopeningen. De Medische en paramedische beroepen vertonen de laagste totale vraag met $18 \%$ van de werkgelegenheid. De verklaring hiervoor ligt mede in de 
eerder geconstateerde vertraging in de werkgelegenheidsgroei voor de Kwartiaire sector (waaronder de gezondheidszorg) op de middellange termijn.

Voor sommige beroepsklassen vormt de uitbreidingsvraag de voornaamste bron van vraag naar nieuwe arbeidskrachten, voor andere is juist de vervangingsvraag van belang. Figuur 3.6 geeft per beroepsklasse het aandeel van uitbreidingsvraag en vervangingsvraag in de baanopeningen op de middellange termijn voor Gelderland.

Figuur 3.6

Aandeel positieve uitbreidingsvraag en vervangingsvraag in de totale vraag, 2001-2006, Gelderland

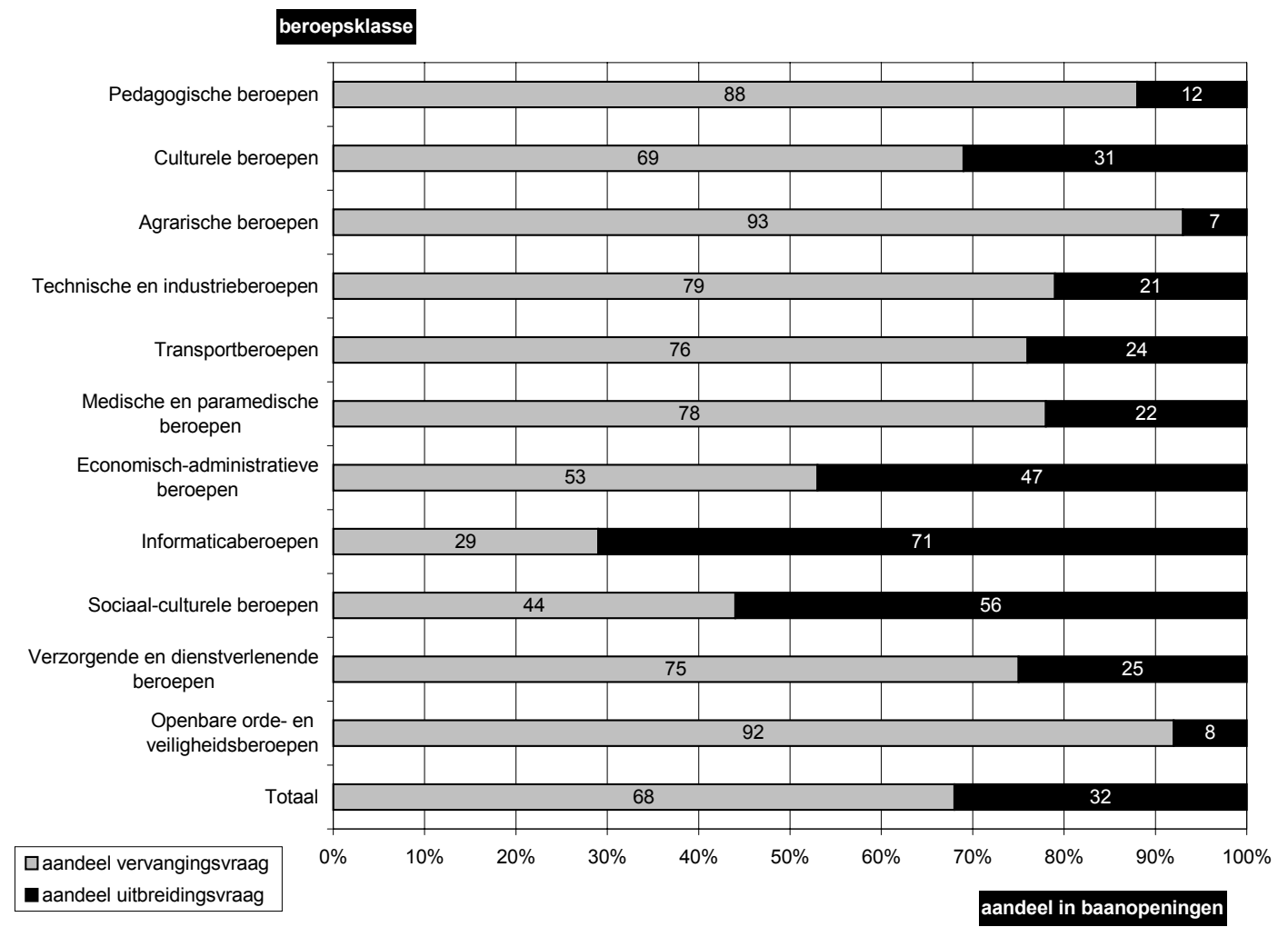

Bron: ROA

Gemiddeld genomen is de vervangingsvraag met een aandeel van $68 \%$ de belangrijkste component van de vraag naar nieuwe arbeidskrachten per beroep. Alleen voor de vraag bij de Informaticaberoepen en de Sociaal-culturele beroepen vormt de uitbreidingsvraag de voornaamste bron. Voor alle andere beroepsklassen is de vervangingsvraag verantwoordelijk voor meer dan de helft van de baanopeningen. De vervangingsvraag is met name belangrijk voor de Agrarische beroepen, de Openbare orde- en veiligheidsberoepen en de Pedagogische beroepen. Een verklaring hiervoor is dat deze beroepsklassen relatief zware arbeidsomstandigheden kennen en een relatief vergrijsd personeelsbestand hebben. 
Figuur 3.7 geeft de baanopeningen tot 2006 weer voor Gelderland en Nederland. Naar verwachting is de totale vraag in Gelderland groter dan in Nederland als geheel, $25 \%$ tegenover $22 \%$. Dit geldt voor alle beroepsklassen met uitzondering van de Pedagogische beroepen en de Medische en paramedische beroepen. Voor de pedagogische beroepen is dit verschil met Nederland te wijten aan de achterblijvende uitbreidingsvraag, voor de Medische en paramedische beroepen is zowel een lagere uitbreidingsvraag als een lagere vervangingsvraag hier debet aan.

Figuur 3.7

Verwachte baanopeningen, 2001-2006, Gelderland en Nederland

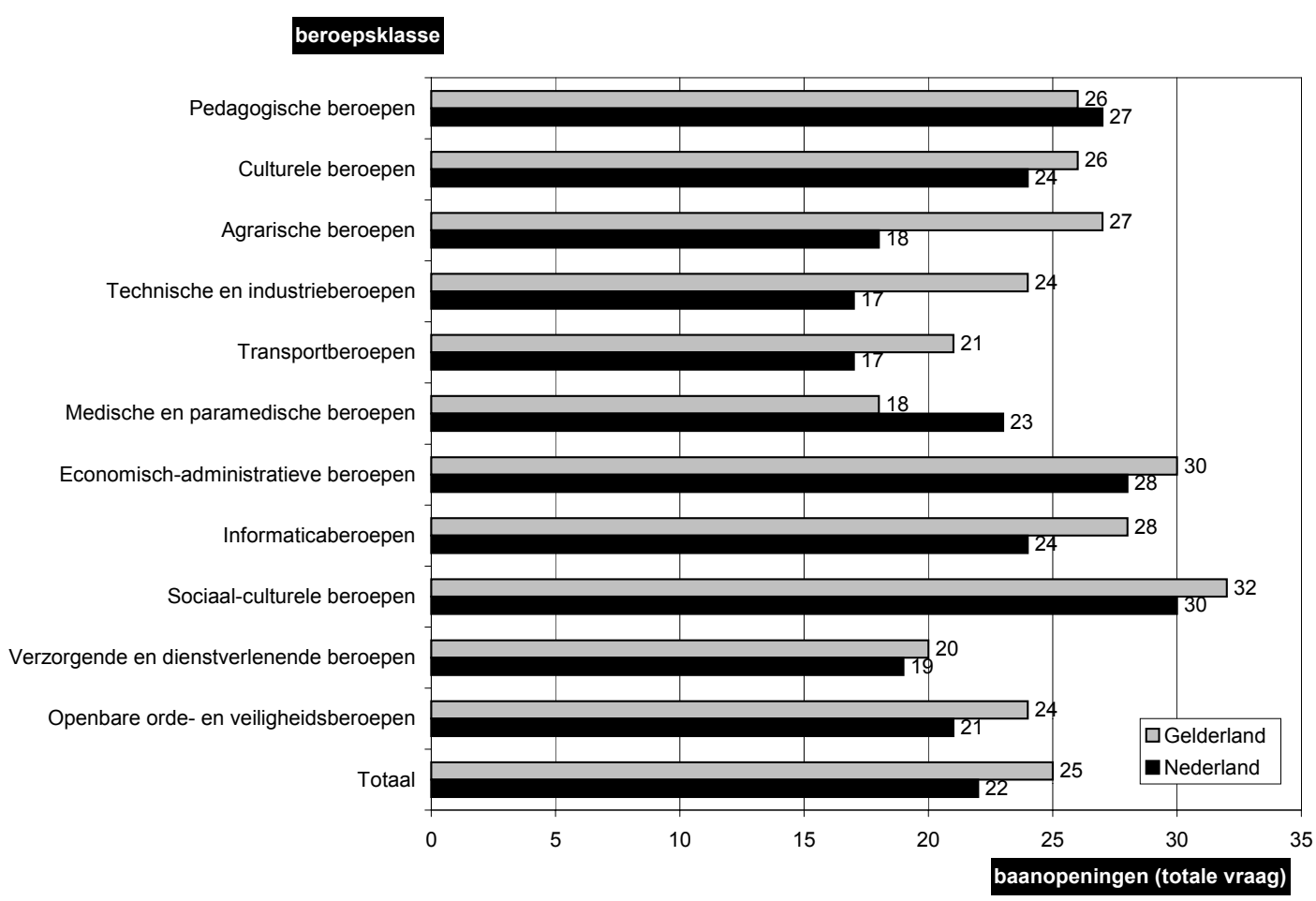

Bron: ROA

In het volgende kader staan de beroepsgroepen met de relatief hoogste en laagste percentages baanopeningen voor Gelderland op de korte en middellange termijn. Opvallend is dat voor de informatici in 2003 relatief weinig baanopeningen worden verwacht. De groei van de baanopeningen voor deze beroepsgroep herstelt zich naar verwachting echter goed op de middellange termijn. Op de middellange termijn hebben immers de Informaticaberoepen een hoge totale vraag. 
KORTE TERMIJN:

Beroepsgroepen met een relatief hoog percentage baanopeningen in Gelderland:

- Confectie-arbeiders

- Juridisch en fiscaal medewerkers

- Hoofden technische dienst

- Weg- en waterbouwkundige vakkrachten

- Docenten exacte, medische en verzorgende vakken $\left(1^{\mathrm{e}}\right.$ graads)

- Docenten landbouw en techniek $\left(2^{\mathrm{e}}\right.$ en $3^{\mathrm{e}}$ graads)

- Elektromonteurs

Beroepsgroepen met een relatief laag percentage baanopeningen

in Gelderland:

- Verpleeghulpen en leerling-verpleegkundigen

- Informatici

- Laders en lossers

- Verkopers

- Verzorgend personeel

\section{MIDDELLANGE TERMIJN:}

Beroepsgroepen met een relatief hoog percentage baanopeningen in Gelderland:

- Organisatie-adviseurs

- Accountants

- Leidinggevenden

- Organisatie-deskundigen

- Productieplanners

- Managers

Beroepsgroepen met een relatief laag percentage baanopeningen in Gelderland:

- Verpleeghulpen en leerling-verpleegkundigen

- Confectie-arbeiders

- Verzorgend personeel

- Verplegenden en doktersassistenten

- Verkopers

\section{Opleidingssectoren}

In tabel 3.7 staan de verwachte baanopeningen naar opleidingssector voor Gelderland op de korte en middellange termijn weergegeven als percentage van de werkgelegenheid. Op de korte termijn komt de totale vraag uit op 5,5\%, hetgeen equivalent is aan 44.700 personen. $^{17}$

17. De baanopeningen naar beroepsklasse en opleidingssector worden op een verschillende manier gemeten, mede doordat de vervangingsvraag verschilt, maar ook door een andere waarneming van de werkgelegenheidskrimp op het lage aggregatieniveau van beroepsgroepen en opleidingstypen. 
De hoge totale vraag van de opleidingen Basisonderwijs en HAVO/VWO is deels toe te schrijven aan het belang dat 'doorleerders' hebben binnen de vervangingsvraag voor deze opleidingen. Verder is op de korte termijn de vraag groot bij WO Medisch, HBO Paramedisch, HBO Techniek en VMBO Landbouw en natuurlijke omgeving. Een uitgesproken lage vraag wordt verwacht voor de hogere landbouwopleidingen MBO Landbouw en natuurlijke omgeving, HBO Landbouw en WO Landbouw en milieukunde. Ook is de totale vraag voor de korte termijn laag voor WO Economie.

Tabel 3.7

Verwachte baanopeningen naar opleidingssector op korte en middellange termijn, Gelderland

\begin{tabular}{|c|c|c|}
\hline Opleidingssector & $\begin{array}{r}\text { Gelderland } \\
2003 \\
\%\end{array}$ & $\begin{array}{r}\text { Gelderland } \\
\text { 2001-2006 } \\
\%\end{array}$ \\
\hline Basisonderwijs & 7,5 & 39 \\
\hline VMBO Theorie & 4,9 & 26 \\
\hline VMBO Landbouw en natuurlijke omgeving & 6,7 & 34 \\
\hline VMBO Techniek & 4,8 & 25 \\
\hline VMBO Economie & 5,6 & 28 \\
\hline VMBO Verzorging & 4,6 & 24 \\
\hline HAVO/VWO & 6,6 & 46 \\
\hline MBO Landbouw en natuurlijke omgeving & 3,5 & 32 \\
\hline MBO Techniek & 5,2 & 34 \\
\hline MBO Economie & 5,3 & 30 \\
\hline MBO Dienstverlening en gezondheidszorg & 5,3 & 28 \\
\hline HBO Landbouw & 4,3 & 28 \\
\hline HBO Techniek & 6,6 & 35 \\
\hline HBO Economie & 4,8 & 34 \\
\hline HBO Onderwijs en sociaal-cultureel & 5,8 & 31 \\
\hline HBO Paramedisch & 6,4 & 39 \\
\hline WO Landbouw en milieukunde & 3,9 & 26 \\
\hline WO Techniek & 4,8 & 32 \\
\hline WO Economie & 4,2 & 40 \\
\hline WO Letteren en sociaal-cultureel & 5,5 & 38 \\
\hline WO Medisch & 7,1 & 20 \\
\hline Totaal & 5,5 & 32 \\
\hline
\end{tabular}

Bron: ROA

Dat de totale vraagverwachting tussen de korte en de middellange termijn niet constant is, blijkt uit het feit dat sommige opleidingssectoren van een relatief lage vraag omslaan naar relatief hoge vraag, of omgekeerd. WO Economie gaat bijvoorbeeld van een relatief lage vraag van $(4,2 \%)$ naar een relatief hoge vraag (40\%). Omgekeerd zakt de hoge vraag op de korte termijn naar arbeidskrachten met als opleidingsachtergrond WO medisch $(7,1 \%)$ op de middellange termijn in tot ver beneden het gemiddelde (20\%). 
Figuur 3.8

Aandeel uitbreidingsvraag en vervangingsvraag in de totale vraag, 2001-2006, Gelderland

\section{opleidingssector}

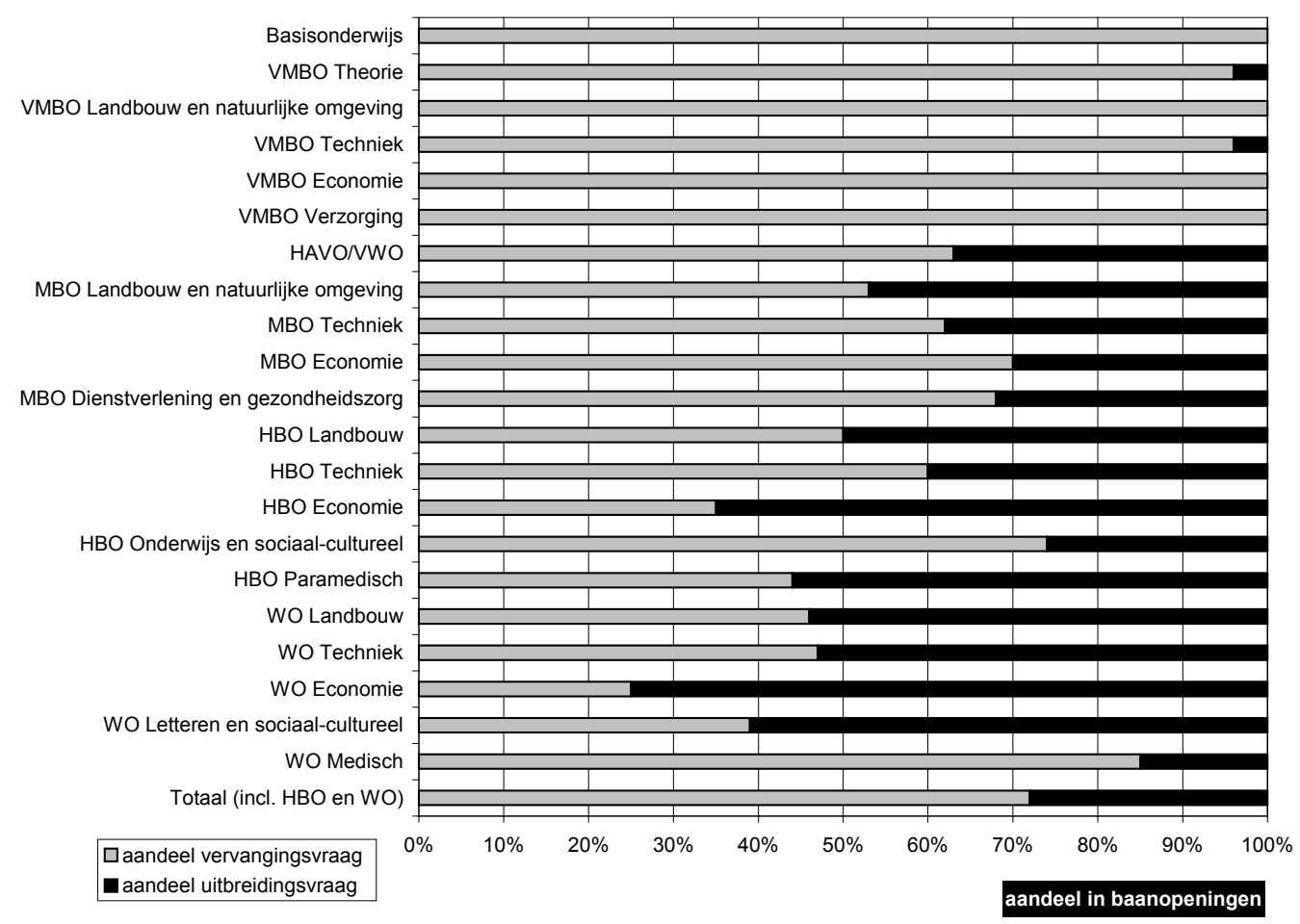

Bron: ROA

In figuur 3.8 staat het relatieve aandeel van (positieve) uitbreidingsvraag en vervangingsvraag in de uiteindelijke baanopeningen weergegeven. Voor de meeste opleidingssectoren geldt hetzelfde als wat voor de totale arbeidsmarkt geldt, namelijk dat de vervangingsvraag de voornaamste bron van de vraag naar nieuwe arbeidskrachten vormt. Vooral Basisonderwijs, de VMBO-sectoren en WO Medisch steunen zwaar op de vervangingsvraag. HBO Economie en WO Economie zijn groeiende opleidingssectoren waardoor het belang van de vervangingsvraag in het totale aantal baanopeningen minder dan $40 \%$ bedraagt.

Figuur 3.9 zet de totale vraag op de middellange termijn van Gelderland af tegen die van Nederland. De verwachte baanopeningen zijn voor alle opleidingssectoren in Gelderland groter dan of gelijk aan de landelijke prognoses. MBO Dienstverlening en gezondheidszorg en HBO Onderwijs en sociaal-cultureel vertonen in Gelderland en Nederland gelijke totale vraagverwachtingen. Voor alle andere opleidingen overtreft de Gelderse vraag de landelijke. In sommige gevallen is het verschil erg groot. Met name voor VMBO landbouw ligt het percentage ver uit elkaar vanwege het verschil in vervangingsvraag. 
Figuur 3.9

Verwachte baanopeningen naar opleidingssector, 2001-2006, Gelderland en Nederland

\section{opleidingssector}

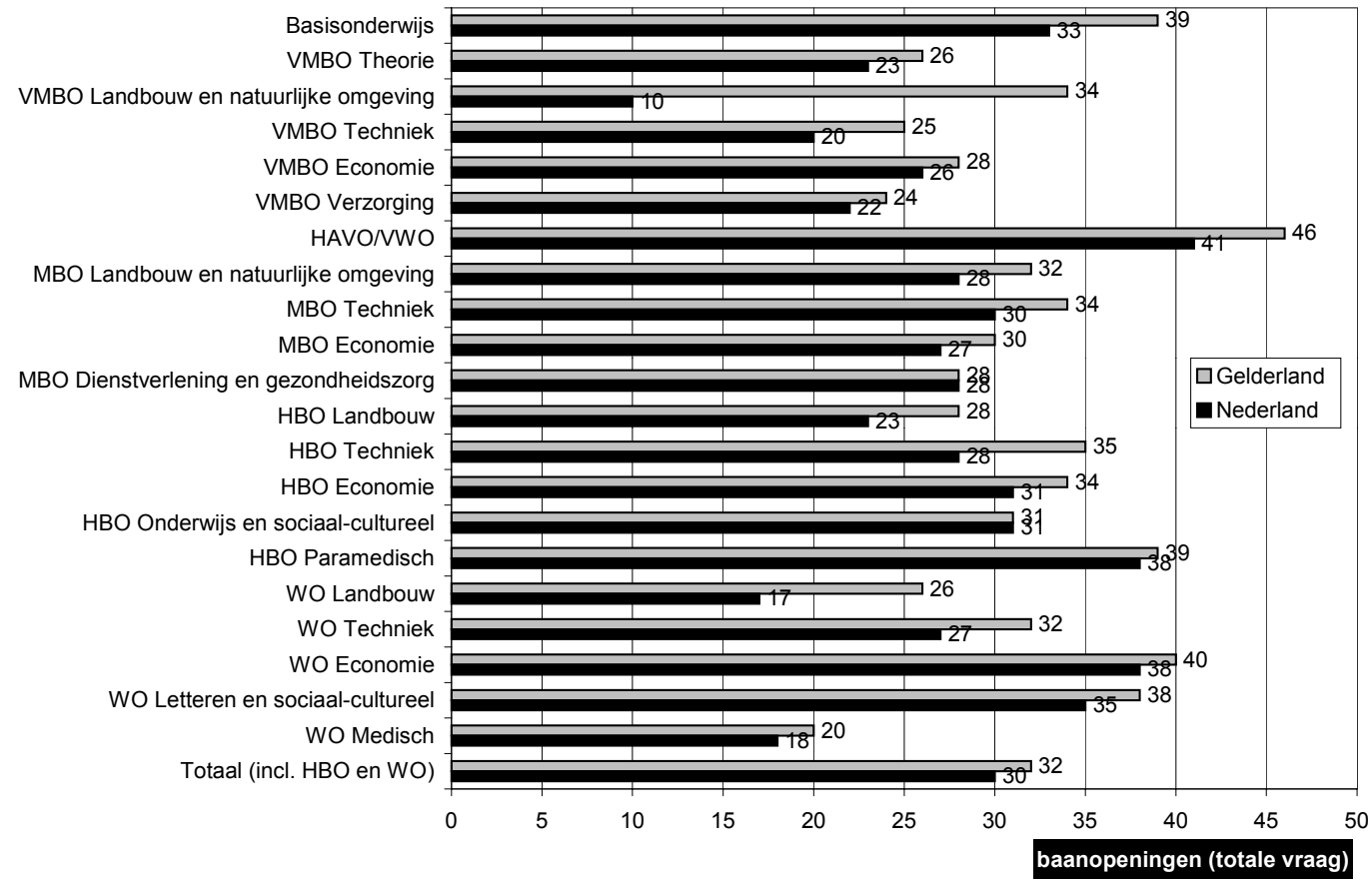

Bron: ROA

In het volgende kader staan beroepen en opleidingen met relatief hoge of relatief lage percentages baanopeningen voor Gelderland. De verzameling van opleidingstypen in dit kader is redelijk divers. Het enige opleidingstype dat zowel op de korte als de middellange termijn voorkomt in het kader, met een hoge uitbreidingsvraag, is MBO toerisme en recreatie. 


\section{KORTE TERMIJN:}

Opleidingstypen met een relatief hoog percentage baanopeningen

in Gelderland:

- MBO toerisme en recreatie

- HBO personeelswerk

- HBO lerarenopleiding economie en maatschappij

- HBO maatschappelijk werk en hulpverlening

- HBO laboratorium

- WO tandheelkunde

Opleidingstypen met een relatief laag percentage baanopeningen in Gelderland:

- MBO groene ruimte

- MBO (uiterlijke) verzorging

- MBO horeca

- MBO grond-, weg- en waterbouw

- MBO voeding, natuur en milieu

- MBO levensmiddelentechniek/vleesverwerking

\section{MIDDELLANGE TERMIJN:}

Opleidingstypen met een relatief hoog percentage baanopeningen in Gelderland:

- MBO toerisme en recreatie

- MBO bouw

- HBO lerarenopleiding economie en maatschappij

- HAVO/VWO

- HBO (fysio)therapie

- WO bedrijfskunde

- WO econom(etr)ie

Opleidingstypen met een relatief laag percentage baanopeningen in Gelderland:

- VMBO elektrotechniek

- HBO milieukunde en levensmiddelentechnologie

- VMBO bouwtechniek

- MBO handel

- HBO laboratorium

- WO (dier)geneeskunde

\subsection{Aanbod van schoolverlaters}

In de voorgaande paragrafen zijn de verwachte ontwikkelingen aan de vraagzijde van de Gelderse arbeidsmarkt op de korte en de middellange termijn geschetst, hetgeen resulteerde in de baanopeningen voor nieuwkomers op de arbeidsmarkt. Als aanbod staat, naast de kortdurig werklozen, hier met name de verwachte arbeids- 
marktinstroom van schoolverlaters tegenover. ${ }^{18}$ In deze paragraaf wordt een overzicht gegeven van het aanbod van schoolverlaters op de arbeidsmarkt voor de korte en middellange termijn. Dit overzicht beperkt zich in het onderhavige rapport tot de lagere en middelbare opleidingssectoren. Omdat afgestudeerden van het hoger onderwijs een grote geografische mobiliteit laten zien, worden voor de opleidingen van het $\mathrm{HBO}$ en WO geen regionale instroomprognoses gepresenteerd. ${ }^{19}$

\section{Opleidingssectoren}

De verwachte arbeidsmarktinstroom van schoolverlaters schommelt voor de meeste lagere en middelbare opleidingssectoren op de korte termijn rond de $5 \%$, met drie belangrijke uitschieters: VMBO Landbouw en natuurlijke omgeving, VMBO economie en HAVO/VWO. Ook voor de middellange termijn zijn deze drie opleidingssectoren de uitschieters. De arbeidsmarktinstroom vanuit de verschillende VMBO-opleidingen en het HAVO/VWO is voor een belangrijk deel afkomstig van werkenden die postinitieel een dergelijke opleiding hebben gevolgd. Door het afronden van één van deze opleidingen ontstaat er aan de vraagzijde vervangingsvraag naar arbeidskrachten met de 'oude' opleidingsachtergrond (bijv. ongeschoolden).

Tabel 3.9

Verwachte arbeidsmarktinstroom van schoolverlaters naar opleidingssector (als \% van de werkgelegenheid in het basisjaar) op korte termijn en middellange termijn, Gelderland

\begin{tabular}{lrr} 
Opleidingssector & $\begin{array}{r}\text { Gelderland } \\
2003\end{array}$ & $\begin{array}{r}\text { Gelderland } \\
2001-2006 \\
\%\end{array}$ \\
& $\%$ & 23 \\
\hline & & 25 \\
Basisonderwijs & 4,6 & 54 \\
VMBO Theorie & 5,0 & 20 \\
VMBO Landbouw en natuurlijke omgeving & 10,9 & 69 \\
VMBO Techniek & 4,0 & 25 \\
VMBO Economie & 13,9 & 50 \\
VMBO Verzorging & 5,0 & 28 \\
HAVO/VWO & 9,9 & 23 \\
MBO Landbouw en natuurlijke omgeving & 5,5 & 25 \\
MBO Techniek & 4,5 & 25 \\
MBO Economie & 5,0 & \\
MBO Dienstverlening en gezondheidszorg & 4,9 & 25 \\
& & \\
Totaal (incl. HBO en WO) & 4,9 & \\
& &
\end{tabular}

Bron: ROA

18. Met de arbeidsmarktinstroom van herintreders is reeds, impliciet, rekening gehouden bij het bepalen van de vervangingsvraag.

19. Voor de landelijke instroomprognoses voor de periode 2001-2006 van de HBO- en WOopleidingen wordt de geïnteresseerde lezer verwezen naar ROA (2001), De arbeidsmarkt naar opleiding en beroep tot 2006, ROA-R-2001/8, Maastricht. 
De arbeidsmarktinstroom op de middellange termijn levert voor Gelderland en Nederland een vergelijkbaar beeld op. Op MBO-niveau ligt de arbeidsmarktinstroom voor de middellange termijn over het algemeen wat hoger dan voor Nederland. Voor de lagere opleidingssectoren is de Gelderse arbeidsmarktinstroom voor de middellange termijn relatief lager voor Basisonderwijs, VMBO Verzorging en HAVO/VWO. Daarentegen is voor VMBO Landbouw en natuurlijke omgeving en $V M B O$ Economie de arbeidsmarktinstroom van schoolverlaters aanzienlijk groter dan landelijk.

Figuur 3.10

Verwachte arbeidsmarktinstroom naar opleidingssector, 2001-2006, Gelderland en Nederland

\section{opleidingssector}

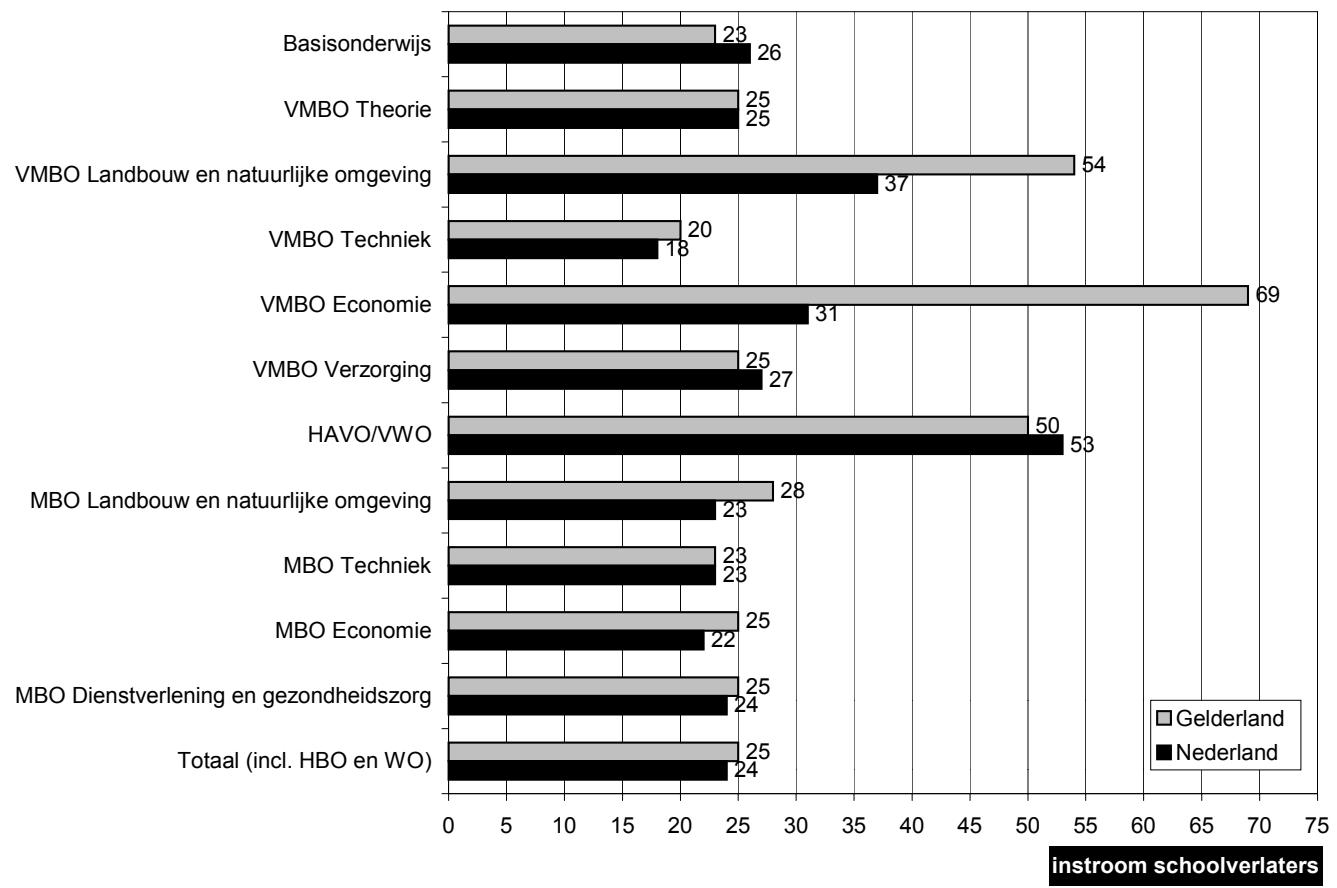

Bron: ROA 
Uit het onderstaand overzicht blijkt dat de lagere en middelbare opleidingstypen met de grootste en de kleinste instroom van schoolverlaters op de Gelderse arbeidsmarkt voor de korte en middellange termijn dezelfde zijn.

\section{KORTE TERMIJN:}

Lagere en middelbare opleidingstypen met een relatief hoge arbeidsmarktinstroom van schoolverlaters in Gelderland:

- VMBO landbouw en natuurlijke omgeving

- VMBO horeca en levensmiddelentechniek

- VMBO administratie, handel en textiel

- MBO toerisme en recreatie

- MBO sociaal-pedagogisch en welzijn

- HAVO/VWO

Lagere en middelbare opleidingstypen met een relatief lage arbeidsmarktinstroom van schoolverlaters in Gelderland:

- VMBO fijnmechanische techniek

- VMBO vervoer

- MBO geld, bank en belastingen

- MBO openbare orde en veiligheid

\section{MIDDELLANGE TERMIJN:}

Lagere en middelbare opleidingstypen met een relatief hoge arbeidsmarktinstroom van schoolverlaters in Gelderland:

- VMBO landbouw en natuurlijke omgeving

- VMBO horeca en levensmiddelentechniek

- VMBO administratie, handel en textiel

- MBO toerisme en recreatie

- MBO sociaal-pedagogisch en welzijn

- HAVO/VWO

Lagere en middelbare opleidingstypen met een relatief lage arbeidsmarktinstroom van schoolverlaters in Gelderland:

- VMBO fijnmechanische techniek

- VMBO vervoer

- MBO geld, bank en belastingen

- MBO openbare orde en veiligheid 



\section{Knelpunten en perspectieven op de Gelderse arbeidsmarkt}

Bij de aansluiting tussen onderwijs en arbeidsmarkt kan een onderscheid worden gemaakt in de toekomstige arbeidsmarktperspectieven voor schoolverlaters en de toekomstige knelpunten in de personeelsvoorziening voor werkgevers. ${ }^{20}$ Op de korte termijn zijn de perspectieven goed voor met name de opleidingssectoren (V)MBO Techniek, VMBO Verzorging en MBO Dienstverlening en gezondheidszorg. Voor de VMBO-opleidingssectoren is dat wat betreft de vraagzijde uits/uitend gebaseerd op het hoge aandeel van de vervangingsvraag in de baanopeningen, terwijl voor de MBO-opleidingssectoren ook de uitbreidingsvraag in belangrijke mate bijdraagt aan de totale vraag. Werkgevers kunnen voor 2003 knelpunten in de personeelsvoorziening verwachten in beroepen waarbij een dergelijke opleidingsachtergrond vereist is. Zo worden op de korte termijn in vrijwel elke beroepsklasse enige tot grote knelpunten verwacht in de personeelsvoorziening voor werkgevers. Een uitzondering zijn de openbare orde- en veiligheidsberoepen.

Op de middellange termijn zijn de toekomstige arbeidsmarktperspectieven voor schoolverlaters beter dan op de korte termijn voor vrijwel elke opleidingssector. Alleen schoolverlaters die VMBO Landbouw en natuurlijke omgeving en VMBO economie als opleidingsachtergrond hebben, kunnen op de middellange termijn verwachten dat de arbeidsmarktperspectieven nog verder verslechteren.

Meer dan tweederde van de schoolverlaters met een laag opleidingsniveau beschikt over grote tot zeer grote uitwijkmogelijkheden op de arbeidsmarkt. De keerzijde hiervan is dat zij veelal geen sterke concurrentiepositie innemen op een bepaald beroependomein. Van de totale Gelderse werkzame beroepsbevolking beschikt $41 \%$ over dergelijke grote uitwijkmogelijkheden.

Werkgevers zijn gedwongen om te zoeken naar oplossingen om toekomstige tekorten in de personeelsvoorziening op te vangen. De substitutiemogelijkheden voor Gelderse werkgevers in beroepsgroepen waarvoor grote tot zeer grote knelpunten in de personeelsvoorziening verwacht worden zijn voor $54 \%$ van de werkenden groot tot zeer groot. Dit houdt in dat werkgevers arbeidskrachten kunnen aantrekken met uiteenlopende opleidingsachtergronden om de baanopeningen in te vullen. In de beroepsklasse van de Pedagogische beroepen worden echter grote knelpunten in de personeelsvoorziening verwacht terwijl de substitutiemogelijkheden voor werkgevers heel klein zijn.

20. De opleidingen van het HBO en het WO blijven hier buiten beschouwing, omdat de arbeidsmarktperspectieven voor deze opleidingen vooral bepaald worden door het landelijke beeld (zie ook paragraaf 3.5). Dit hangt samen met het gegeven dat de instroom van afgestudeerden van het hoger onderwijs op de arbeidsmarkt een grote geografische mobiliteit vertoont. Zie voor de landelijke arbeidsmarktperspectieven voor HBO- en WOopleidingen (ROA, 2001), De arbeidsmarkt naar opleiding en beroep tot 2006, ROA-R2001/8, Maastricht. 


\subsection{Inleiding}

In dit hoofdstuk zal worden ingegaan op zowel de kortetermijn- als de middellangetermijnprognoses van de ontwikkelingen op de Gelderse arbeidsmarkt. De ontwikkelingen met betrekking tot de uitbreidingsvraag, vervangingsvraag, baanopeningen en instroom van schoolverlaters zijn al besproken in het voorgaande hoofdstuk. In dit hoofdstuk zal de nadruk liggen op de arbeidsmarktperspectieven van schoolverlaters en de knelpunten in de personeelsvoorziening voor de werkgevers. Dit houdt in dat de vraag- en aanbodcomponenten met elkaar worden geconfronteerd.

De voorgaande twee hoofdstukken gaven de verwachting weer met betrekking tot de vraag- en aanbodkant van de Gelderse arbeidsmarkt in 2003. Tevens gaven deze hoofdstukken een overzicht van de arbeidsmarktsituatie op de middellange termijn. De verwachte arbeidsmarktsituatie in 2006 kan belicht worden vanuit het oogpunt van de werkgevers maar ook vanuit de toekomstige werknemers. Voor de werkgevers is het van belang een indicatie te krijgen van de verwachte knelpunten in de personeelsvoorziening die ze kunnen verwachten in de beroepssector waar ze personeel werven. Aan de hand van deze indicatie kunnen werkgevers of sectoren besluiten hun personeel elders te werven of door preventief arbeidsmarktbeleid de instroom van schoolverlaters te vergroten indien er sprake zou zijn van verwachte tekorten van personeel.

De arbeidsmarktperspectieven voor schoolverlaters op de arbeidsmarkt zal worden besproken aan de hand van de Indicator Toekomstperspectieven op de Arbeidsmarkt (ITA) en de knelpunten in de personeelsvoorziening voor de werkgevers aan de hand van de Indicator Toekomstige Knelpunten in de personeelsvoorziening naar Beroep (ITKB). De Indicator Toekomstige Arbeidsmarktperspectieven (ITA) geeft een indicatie van de arbeidsmarktperspectieven voor schoolverlaters en werkzoekenden en geeft aan wat hun kansen zijn op de arbeidsmarkt. Een ITA die groter is dan één geeft een ongunstige arbeidsmarkt weer voor schoolverlaters en werkzoekenden. Indien de ITA namelijk groter is dan één is er meer aanbod van arbeid dan vraag. Met andere woorden er is een overschot aan arbeidskrachten op de arbeidsmarkt. Indien de ITA kleiner is dan één is er sprake van een gunstige arbeidsmarkt voor schoolverlaters en werkzoekenden. Het aanbod van werkenden is dan kleiner dan de vraag.

Naast de indicator voor werknemers wordt er ook een indicator voor werkgevers gegeven. De Indicator Toekomstige Knelpunten in de personeelsvoorziening naar Beroep (ITKB) geeft een indicatie van de verwachte knelpunten die werkgevers zullen ondervinden bij het aantrekken van nieuw personeel. De interpretatie van de ITKB is gelijk aan die van de ITA. Dit betekent dat een ITKB van groter dan één aangeeft dat er meer aanbod van personeel is dan dat er vraag naar personeel is. $\mathrm{Er}$ zullen dan geen knelpunten zijn bij de werving van nieuw personeel. Een ITKB die kleiner is dan één geeft aan dat de vraag naar personeel groter is dan het aanbod. De werkgevers zullen problemen ondervinden bij het aantrekken van personeel, dus er zullen knelpunten optreden op het betreffende segment van de arbeidsmarkt. 
Bij een aanbodoverschot is het niet vanzelfsprekend dat schoolverlaters werkloos zullen worden, evenals dat het bij een vraagoverschot niet vanzelfsprekend is dat er onvervulde vacatures zijn. Het is namelijk ook mogelijk dat werkgevers hun eisen aanpassen aan de arbeidsmarktsituatie op dat moment. Bij een vraagoverschot op specifieke opleidingssegment zouden werkgevers ook personeel kunnen werven dat niet volledig beschikt over de benodigde kwalificaties. Deze mensen zouden dan indien nodig aan de hand van om- of bijscholingsprogramma's opgeleid kunnen worden om aan de kwalificatievereisten voor de banen met knelpunten in de personeelsvoorziening te voldoen. Naast het aanpassen van de benodigde kwalificaties kunnen werkgevers ook personeel werven uit verder weg gelegen regio's (hoofdstuk 5 ) of het onbenutte arbeidspotentieel van niet-actieven aanboren (hoofdstuk 6) om vacatures te vervullen.

In paragraaf 4.2 worden de korte- en middellangetermijnperspectieven naar opleidingssector gepresenteerd. Vervolgens worden in paragraaf 4.3 de toekomstige knelpunten in de personeelsvoorziening besproken voor de korte en de middellange termijn. Tot slot komen in paragraaf 4.4 de uitwijkmogelijkheden voor schoolverlaters en in paragraaf 4.5 de substitutiemogelijkheden voor werkgevers aan bod.

\subsection{De arbeidsmarktperspectieven voor schoolverlaters}

De verwachtingen voor de korte termijn naar opleiding

Tabel 4.1 presenteert de Indicator Toekomstig Arbeidsmarktperspectief (ITA) met bijbehorende typeringen voor Gelderland in 2002 voor de lagere en middelbare opleidingssectoren. Deze indicator geeft voor elke opleidingssector de verhouding tussen het arbeidsaanbod met de betreffende opleidingsachtergrond en de daar tegenoverstaande vraag. Als het arbeidsaanbod kleiner is dan de vraag (dit komt overeen met een ITA die kleiner of gelijk is aan 1,00) wordt het arbeidsmarktperspectief als goed of zeer goed getypeerd. Schoolverlaters en werkzoekenden zullen relatief gemakkelijk een baan vinden in de beroepsgroep waarvoor hun opleidingsachtergrond vereist is. Voor werkgevers daarentegen zal het juist moeilijk zijn om schoolverlaters met deze opleidingsachtergrond aan te trekken. Een goed arbeidsmarktperspectief voor schoolverlaters en werkzoekenden zal doorgaans samenvallen met grote knelpunten in de personeelsvoorziening voor werkgevers.

Tabel 4.1 laat zien dat voor de schoolverlaters van de opleidingssectoren Basisonderwijs, VMBO Theorie, VMBO Techniek, VMBO Verzorging, MBO Techniek en $M B O$ Dienstverlening en gezondheidszorg de arbeidsmarktperspectieven goed zijn. Degenen die een opleiding binnen één van deze opleidingssectoren hebben afgerond en op zoek zijn naar een baan hebben de grootste kans op het vinden van een baan. Dit goede arbeidsmarktperspectief wordt voor de opleidingssectoren Basisonderwijs, VMBO Theorie, VMBO Techniek en VMBO Verzorging veroorzaakt door een relatief iets hogere vervangingsvraag bij een gemiddelde arbeidsmarktinstroom. Dit betekent dat er relatief veel baanopeningen zullen zijn in 
deze opleidingssectoren. De goede toekomstige arbeidsmarktperspectieven voor de opleidingssectoren MBO Techniek en Dienstverlening en gezondheidszorg wordt veroorzaakt door een relatief lage instroom van schoolverlaters op de arbeidsmarkt. Ook dit houdt in dat er naar verwachting relatief veel baanopeningen zullen zijn voor schoolverlaters met deze opleidingsachtergrond. Voor de andere opleidingssectoren geldt dat de arbeidsmarktperspectieven naar verwachting redelijk tot matig zijn.

Tabel 4.1

Indicator Toekomstige Arbeidsmarktperspectieven (ITA) per opleidingssector in 2003, Gelderland

\begin{tabular}{lll}
\hline Opleidingssector & ITA & typering \\
\hline & & \\
Basisonderwijs & 0,97 & goed \\
VMBO Theorie & 0,99 & goed \\
VMBO Landbouw en natuurlijke omgeving & 1,06 & matig \\
VMBO Techniek & 1,00 & goed \\
VMBO Economie & 1,08 & matig \\
VMBO Verzorging & 1,00 & goed \\
HAVO/VWO & 1,01 & redelijk \\
MBO Landbouw en natuurlijke omgeving & 1,03 & redelijk \\
MBO Techniek & 1,00 & goed \\
MBO Economie & 1,01 & redelijk \\
MBO Dienstverlening en gezondheidszorg & 1,00 & goed \\
Totaal & & redelijk \\
\hline
\end{tabular}

Bron: ROA

Het is opmerkelijk dat de schoolverlaters die Basisonderwijs als hoogst voltooide opleiding hebben afgerond een goed arbeidsmarktperspectief hebben, vooral gezien de doorgaans redelijke en matige perspectieven van de schoolverlaters van het $V M B O$. Het perspectief van deze voor het merendeel 'drop-outs' van het VMBO is echter minder rooskleurig als dat het op grond van tabel 4.1 lijkt. De banen waarin zij instromen bieden weinig carrièreperspectief en zijn relatief vaak tijdelijke banen of voor een beperkt aantal uren per week. Mede door de eveneens relatief slechte arbeidsomstandigheden en -voorwaarden zullen werkenden zonder diploma in het voortgezet onderwijs vaak van baan wisselen of op den duur uitstromen van de arbeidsmarkt. Degenen die wel op de arbeidsmarkt blijven volgen relatief vaak een postinitiële opleiding. ${ }^{21}$ Hierdoor ontstaat vervangingsvraag naar ongediplomeerden.

Op het middelbaar niveau valt op dat de schoolverlaters in één van de opleidingssectoren MBO Landbouw en MBO Economie minder kans hebben op een aantrekkelijke baan dan de schoolverlaters van de andere MBO-opleidingen. Dit wordt bij de opleidingssector MBO Landbouw veroorzaakt door lage uitbreidings- en vervangingsvraag en een hoge instroom van schoolverlaters op de arbeidsmarkt. $\mathrm{Er}$ zijn dus in verhouding meer mensen die een opleiding in deze opleidingssector hebben afgerond dan dat er banen zijn. Bij MBO Economie komt dit patroon overigens niet terug.

21. Zie hoofdstuk 5 van De arbeidsmarkt naar opleiding en beroep tot 2006 (ROA, 2001). 60 
De verwachtingen voor de middellange termijn naar opleiding

Tabel 4.2 laat zien dat over het algemeen op de middellange termijn de arbeidsmarktperspectieven voor de schoolverlaters van de lagere opleidingen gunstig zijn. Vooral de schoolverlaters met een opleiding binnen MBO techniek hebben gunstige arbeidsmarktperspectieven. Schoolverlaters van de opleidingsrichtingen HAVO/VWO en vooral VMBO Landbouw en VMBO Economie kunnen daarentegen meer problemen verwachten bij het vinden van een geschikte baan op de middellange termijn.

De keerzijde van de goede perspectieven voor meerdere opleidingssectoren is dat werkgevers voor de middellange termijn knelpunten in de personeelsvoorziening ondervinden. Voor ongeschoolden hebben de werkgevers de mogelijkheid om de uitstroom af te remmen, waardoor de knelpunten hier niet zo groot zullen zijn. Met name voor de verschillende MBO-opleidingssectoren worden grote knelpunten in de personeelsvoorziening verwacht.

Tabel 4.2

Indicator Toekomstige Arbeidsmarktperspectieven (ITA) per opleidingssector tot 2006, Gelderland

\begin{tabular}{lll}
\hline Opleidingssector & ITA & typering \\
& & \\
Basisonderwijs & 0,89 & goed \\
VMBO Theorie & 1,00 & goed \\
VMBO Landbouw en natuurlijke omgeving & 1,17 & slecht \\
VMBO Techniek & 0,97 & goed \\
VMBO Economie & 1,32 & slecht \\
VMBO Verzorging & 1,01 & redelijk \\
HAVO/VWO & 1,03 & redelijk \\
MBO Landbouw en natuurlijke omgeving & 0,97 & goed \\
MBO Techniek & 0,92 & goed \\
MBO Economie & 0,97 & goed \\
MBO Dienstverlening en gezondheidszorg & 0,98 & goed \\
Totaal & & goed \\
\hline
\end{tabular}

Bron: ROA

De slechte middellangetermijnperspectieven voor de opleidingssectoren VMBO Landbouw en VMBO economie wordt net als bij de kortetermijnperspectieven vooral veroorzaakt door de hoge instroom van schoolverlaters. Het aantal baanopeningen weegt niet voldoende op tegen de arbeidsmarktinstroom van schoolverlaters.

De opleidingen met de beste en slechtste arbeidsmarktperspectieven

De goede arbeidsmarktperspectieven op de korte termijn zoals beschreven in tabel 4.1 worden in onderstaand schema verbijzonderd naar opleidingstype. Zo blijkt dat de goede arbeidsmarktperspectieven voor de opleidingssectoren VMBO Techniek, MBO Techniek, Dienstverlening en gezondheidszorg tot uitdrukking komen in de 
onderliggende opleidingstypen VMBO mechanische techniek, MBO werktuigbouw en mechanische techniek en $M B O$ verpleging en verzorging. Deze goede arbeidsmarktperspectieven worden met name veroorzaakt door de lage instroom van schoolverlaters vergeleken met het aantal baanopeningen. Slechte arbeidsmarktperspectieven voor de korte termijn worden verwacht voor de opleidingstypen VMBO landbouw en natuurlijke omgeving en VMBO administratie, handel en textiel. Met name deze opleidingstypen worden gekenmerkt door een te hoge instroom van schoolverlaters vergeleken met het aantal baanopeningen.

\section{Korte termiin:}

Opleidingstypen met gunstige arbeidsmarktperspectieven voor schoolverlaters en werkzoekenden in Gelderland in 2003:

- VMBO vervoer

- $\quad \mathrm{VMBO}$ mechanische techniek

- $\mathrm{MBO}$ werktuigbouw en mechanische techniek

- $\quad \mathrm{MBO}$ geld, bank en belastingen

- $\mathrm{MBO}$ openbare orde en veiligheid

- $\mathrm{MBO}$ verpleging en verzorging

Opleidingstypen met ongunstige arbeidsmarktperspectieven voor schoolverlaters en werkzoekenden in Gelderland in 2003:

- VMBO landbouw en natuurlijke omgeving

- $\quad \mathrm{VMBO}$ administratie, handel en textiel

- $\quad M B O$ groene ruimte

- $\mathrm{MBO}$ sociaal-pedagogisch en welzijn

- $\mathrm{MBO}$ levensmiddelentechniek en vleesverwerking

- $\quad \mathrm{MBO}$ uiterlijke verzorging

Uit tabel 4.2 is gebleken dat op de middellange termijn de arbeidsmarktperspectieven met name voor de opleidingssectoren op MBO-niveau goed zijn. Met name de opleidingstypen MBO bouw, MBO motorvoertuigentechniek, MBO apothekersassistent en $M B O$ toerisme en recreatie worden gekenmerkt door een hoge uitbreidings- dan wel vervangingsvraag terwijl de instroom van schoolverlaters van deze opleidingstypen niet erg hoog is. Dit leidt dus tot gunstige arbeidsmarktperspectieven voor schoolverlaters van deze opleidingstypen.

Slechte arbeidsmarktperspectieven worden verwacht voor VMBO Verzorging en vooral in de opleidingssector $V M B O$ Landbouw. Dit is ook terug te vinden in onderstaand schema waarbij $V M B O$ landbouw en natuurlijke omgeving en $V M B O$ verzorging opleidingstypen zijn die behoren tot deze opleidingssectoren. Er zijn echter ook nog andere opleidingstypen waarvoor slechte arbeidsmarktperspectieven worden verwacht. Zo worden bijvoorbeeld VMBO horeca en levensmiddelentechniek gekenmerkt door een laag aantal baanopeningen terwijl de instroom van 
schoolverlaters van deze opleiding hoog is. Hierdoor is de kans dat mensen met een dergelijke opleidingsachtergrond een geschikte baan vinden klein.

\section{Middellange termijn:}

Opleidingstypen met gunstige arbeidsmarktperspectieven voor schoolverlaters en werkzoekenden in Gelderland tot 2006:

- $\mathrm{MBO}$ bouw

- $\mathrm{MBO}$ installatietechniek

- $\mathrm{MBO}$ motorvoertuigentechniek

- $\mathrm{MBO}$ apothekersassistent

- $\mathrm{MBO}$ openbare orde en veiligheid

- $\mathrm{MBO}$ toerisme en recreatie

Opleidingstypen met ongunstige arbeidsmarktperspectieven voor schoolverlaters en werkzoekenden in Gelderland tot 2006:

- $\quad \mathrm{VMBO}$ landbouw en natuurlijke omgeving

- VMBO motorvoertuigentechniek

- $\quad \mathrm{VMBO}$ horeca en levensmiddelentechniek

- $\quad$ VMBO verzorging

- $\quad \mathrm{VMBO}$ administratie, handel en textiel

- $\mathrm{MBO}$ beweging en therapie

\subsection{Knelpunten in de personeelsvoorziening voor werkgevers}

\section{De verwachtingen voor de korte termijn naar beroep}

Werkgevers zullen veelal vanuit hun organisatieperspectief willen weten waar de baanopeningen in de toekomst zullen gaan optreden om het personeelsbeleid een nadere invulling te kunnen geven. In eerste instantie zullen zij vooral knelpunten voor het vervullen van bepaalde functies ondervinden. Op deze functies kunnen vaak schoolverlaters en werkzoekenden met een uiteenlopende opleidingsachtergrond worden ingezet. De Indicator Toekomstige Knelpunten in de personeelsvoorziening naar Beroep (ITKB) houdt rekening met de verwachte schaarste op de arbeidsmarkt voor de verschillende relevante opleidingstypen per beroep. Indien er een sterke één-op-één relatie is tussen opleiding en beroep, zoals in de zorg en het onderwijs, komt de verwachte vraag-aanbod verhouding voor deze opleidingen en beroepen uiteraard grotendeels overeen. Zeker op de korte termijn zijn de mogelijke strategieën voor werkgevers om de tekorten op te vangen beperkt, mede door de geringe substitutiemogelijkheden tussen schoolverlaters met een uiteenlopende opleidingsachtergrond. De opleidingsvereisten in met name de zorg en het onderwijs 
liggen in belangrijke mate vast, waardoor werkgevers op dit punt weinig flexibel kunnen zijn in hun aannamebeleid.

Tabel 4.3 geeft de ITKB met bijbehorende typeringen weer voor Gelderland in 2003 per beroepsklasse. Hieruit blijkt dat de knelpunten in de personeelsvoorziening op de korte termijn bij de Pedagogische, Medische en paramedische beroepen en bij de Sociaal-culturele beroepen groot zullen zijn.

Tabel 4.3

Indicator Toekomstige Knelpunten in de personeelsvoorziening naar Beroep (ITKB) per beroepsklasse in 2003, Gelderland

$\begin{array}{lll}\text { Beroepsklasse } & \text { ITKB typering }\end{array}$

\begin{tabular}{lll}
\hline & & \\
Pedagogische beroepen & 0,99 & groot \\
Culturele beroepen & 1,03 & enige \\
Agrarische beroepen & 1,03 & enige \\
Technische en industrie beroepen & 1,01 & enige \\
Transportberoepen & 1,01 & enige \\
Medische en paramedische beroepen & 0,99 & groot \\
Economisch-administratieve beroepen & 1,01 & enige \\
Informaticaberoepen & 1,00 & enige \\
Sociaal-culturele beroepen & 0,99 & groot \\
Verzorgende en dienstverlenende beroepen & 1,01 & enige \\
Openbare orde- en veiligheidsberoepen & 1,06 & vrijwel geen \\
& & enige \\
Totaal & 1,01 & \\
\end{tabular}

Bron: ROA

De knelpunten in de personeelsvoorziening bij de Pedagogische beroepen worden veroorzaakt door de zeer lage instroom van schoolverlaters. Zoals vermeld in hoofdstuk 3 zal de werkgelegenheid van onder andere de Sociaal-culturele beroepen en de Medische en paramedische beroepen op de korte termijn zeer sterk toenemen. De werkgelegenheid in deze beroepen zal met meer dan 2,5\% toenemen. Een hoge werkgelegenheidsgroei leidt tot uitbreidingsvraag en doordat de instroom van schoolverlaters deze stijging in de werkgelegenheid niet kan bijbenen, ontstaan er knelpunten. Bij de Pedagogische en (Para)medische beroepen speelt hierbij ook een rol dat de substitutiemogelijkheden voor werkgevers beperkt zijn (zie ook paragraaf 4.5). Bij de Openbare orde en veiligheidsberoepen worden vrijwel geen knelpunten in de personeelsvoorziening verwacht. Dit wordt veroorzaakt doordat op de korte termijn vrijwel geen werkgelegenheidsgroei verwacht wordt.

De verwachtingen voor de middellange termijn naar beroep

De problemen die werkgevers kunnen verwachten op de middellange termijn op de Gelderse arbeidsmarkt bij het aantrekken van nieuw personeel worden weergegeven in tabel 4.4. In de meeste beroepsklassen zijn de rekruteringsproblemen niet groot. Bij de Pedagogische beroepen, Informaticaberoepen en Sociaal-culturele beroepen zijn de knelpunten het grootst. Voor de Agrarische, Culturele en Verzorgende en 
dienstverlenende beroepen hoeft men vrijwel geen knelpunten te verwachten in de personeelsvoorziening. Voor de agrarische sector zou dit veroorzaakt kunnen zijn door stagnatie. ${ }^{22}$

Tabel 4.4

Indicator Toekomstige Knelpunten in de personeelsvoorziening naar Beroep (ITKB) per beroepsklasse tot 2006, Gelderland

\begin{tabular}{lll}
\hline Beroepsklasse & ITKB & typering \\
& & \\
\hline Pedagogische beroepen & 0,95 & groot \\
Culturele beroepen & 1,05 & vrijwel geen \\
Agrarische beroepen & 1,07 & vrijwel geen \\
Technische en industrie beroepen & 1,03 & enige \\
Transportberoepen & 1,03 & enige \\
Medische en paramedische beroepen & 1,04 & enige \\
Economisch-administratieve beroepen & 0,99 & groot \\
Informaticaberoepen & 0,96 & groot \\
Sociaal-culturele beroepen & 0,97 & groot \\
Verzorgende en dienstverlenende beroepen & 1,08 & vrijwel geen \\
Openbare orde- en veiligheidsberoepen & 1,01 & enige \\
& & enige \\
Totaal & 1,02 & \\
& &
\end{tabular}

Bron: ROA, 2002

De knelpunten in de personeelsvoorziening bij de Pedagogische beroepen worden, net als op de korte termijn, veroorzaakt door een zeer lage instroom van schoolverlaters. Het aantal baanopeningen, dat voornamelijk veroorzaakt wordt door vervangingsvraag, kunnen derhalve niet opgevuld worden waardoor werkgevers geconfronteerd zullen worden met knelpunten. Bij de Economisch-administratieve, Sociaal-culturele en Informaticaberoepen worden de knelpunten in de personeelsvoorziening veroorzaakt door de werkgelegenheidsgroei. Een hoge werkgelegenheidsgroei leidt tot uitbreidingsvraag en doordat de instroom van schoolverlaters deze stijging in de werkgelegenheid niet kan bijbenen, ontstaan er knelpunten.

\section{De kleinste en grootste knelpunten naar beroep}

Aan de hand van de knelpunten in de personeelsvoorziening voor werkgevers bij de verschillende beroepsklassen kunnen de achterliggende beroepsgroepen bekeken worden. Uit tabel 4.3 is bijvoorbeeld gebleken dat op de korte termijn grote knelpunten verwacht kunnen worden bij de Medische en paramedische beroepen. Echter, niet alle werkgevers die een vacature open hebben staan in deze beroepsklasse zullen op de korte termijn geconfronteerd worden met knelpunten in de personeelsvoorziening. Aangezien de vooruitzichten voor een beroepsklasse niet identiek zijn voor alle onderliggende beroepsgroepen wordt in onderstaand schema een overzicht van de

22. Volgens Bureau Economisch Onderzoek (2001), Provinciale Economische Verkenning 2000/2001 bepaalt deze stagnatie in de agrarische sector al jaren het ontwikkelingsbeeld van de Achterhoek. 
beroepsgroepen gegeven waarvoor Gelderse werkgevers relatief veel dan wel weinig knelpunten in de personeelsvoorziening kunnen verwachten.

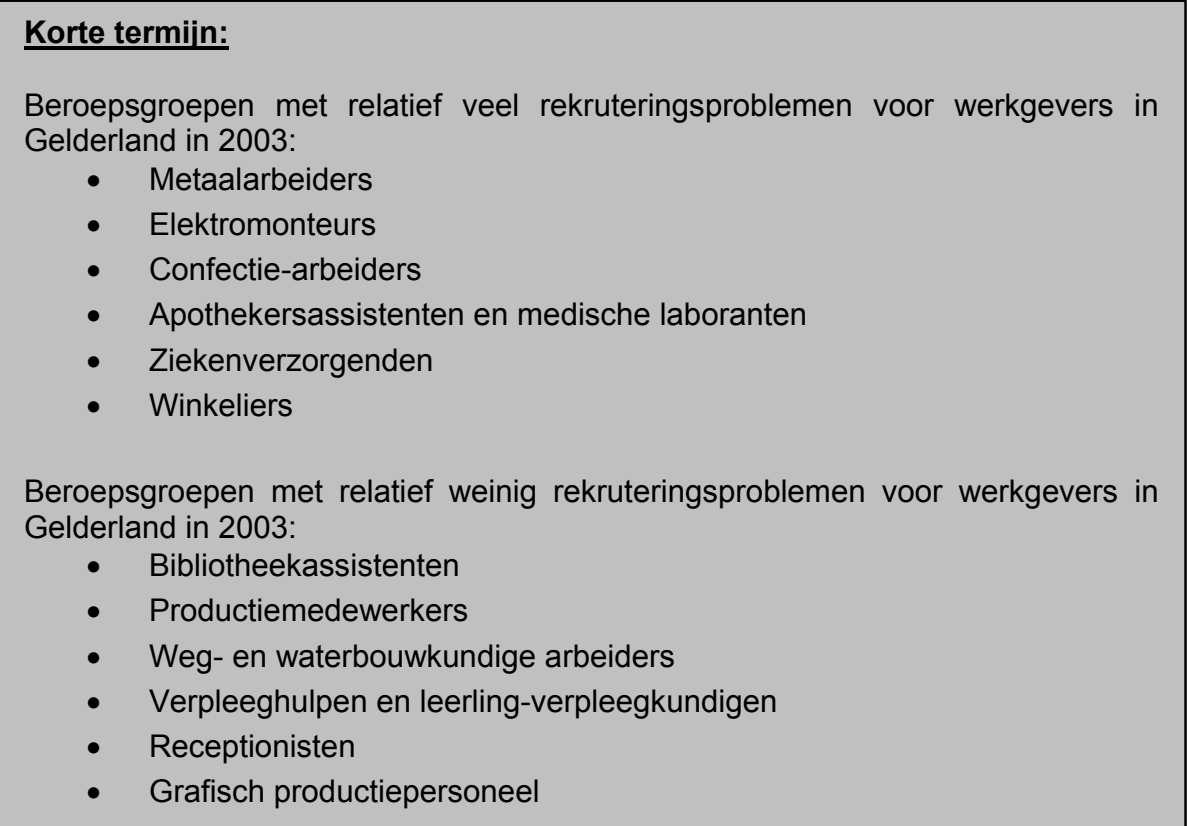

Een oorzaak voor de grote rekruteringsproblemen voor werkgevers bij het werven van elektromonteurs, confectie-arbeiders ${ }^{23}$, ziekenverzorgenden en winkeliers is de (erg) hoge uitbreidings- dan wel vervangingsvraag voor deze beroepsgroepen op de korte termijn. De rekruteringsproblemen in deze beroepsgroepen worden derhalve veroorzaakt door een toename in de werkgelegenheid en een niet corresponderende toename in de instroom van schoolverlaters in deze beroepsgroepen. Derhalve worden op de korte termijn relatief veel rekruteringsproblemen verwacht voor de werkgevers in Gelderland in deze beroepsgroepen.

Weinig rekruteringsproblemen voor werkgevers op de korte termijn worden onder andere verwacht in de beroepsgroepen voor verpleeghulpen en leerling-verpleeghulpen. Dit wordt veroorzaakt door de combinatie van een erg lage uitbreidingsvraag en een gemiddelde instroom van schoolverlaters in deze beroepsgroep. De gemiddelde instroom van schoolverlaters is voor deze beroepsgroep groter dan het aantal baanopeningen waardoor werkgevers weinig moeite hoeven te doen om een geschikte kandidaat te vinden. Dit geldt tevens voor de weg- en waterbouwkundige arbeiders, receptionisten en grafisch productiepersoneel. Voor de resterende beroepsgroepen worden op de korte termijn weinig rekruteringsproblemen voor werkgevers verwacht vanwege een gemiddelde uitbreidings- en vervangingsvraag tegenover een grote arbeidsmarktinstroom van schoolverlaters.

23. Zie over de confectie-arbeiders de opmerking bij het overzichtsschema over de beroepsgroepen in paragraaf 3.2. 
Zowel op de korte termijn als op de middellange termijn zullen werkgevers geconfronteerd worden met rekruteringsproblemen bij de ziekenverzorgenden. Deze beroepsgroep wordt op de korte termijn gekenmerkt door een hoge uitbreidingsvraag. Ook op de middellange termijn zorgt dit voor rekruteringsproblemen. Voor werkgevers die op zoek zijn naar productieplanners geldt voor de middellange termijn hetzelfde als voor de werkgevers die ziekenverzorgenden nodig hebben. De toename in de werkgelegenheid is te groot om alle baanopeningen te kunnen vervullen. Het onderstaande schema geeft een overzicht van de beroepsgroepen met veel en weinig rekruteringsproblemen op de middellange termijn.

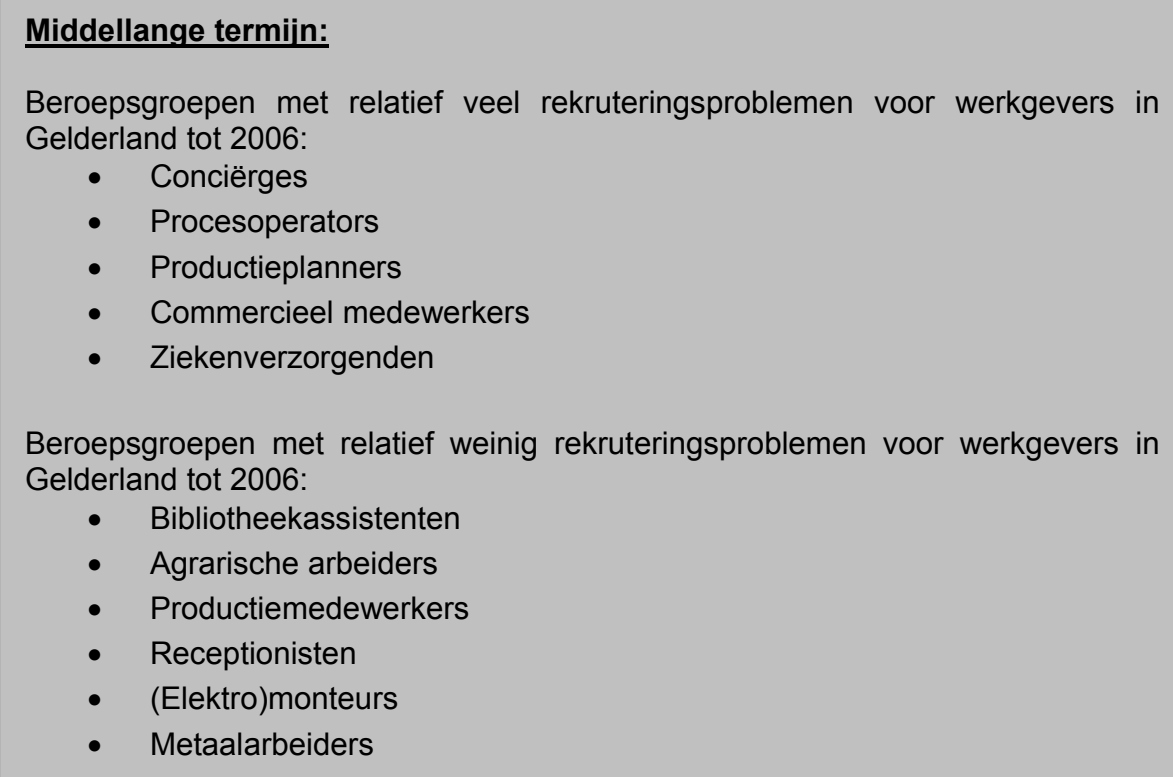

Werkgevers die in 2003 op zoek zijn naar conciërges, procesoperators en commerciële medewerkers hoeven geen rekruteringsproblemen te verwachten. Op de middellange termijn zijn deze naar verwachting echter wel aanwezig. Dit wordt met name veroorzaakt doordat de instroom van schoolverlaters met de vereiste opleidingsachtergrond te laag is om aan de gemiddelde uitbreidings- en vervangingsvraag te kunnen voldoen.

Op de middellange termijn worden weinig rekruteringsproblemen verwacht voor de beroepsgroepen agrarische arbeiders, metaalarbeiders en de receptionisten, welke gekenmerkt worden door een (zeer) lage uitbreidingsvraag. Werkgevers die op zoek zijn naar bibliotheekassistenten, productiemedewerkers of (elektro)monteurs zullen op de middellange termijn te maken krijgen met een gemiddeld aantal baanopeningen. De relatief kleine rekruteringsproblemen in deze beroepsgroepen worden met name veroorzaakt door de (zeer) hoge instroom van schoolverlaters. 


\subsection{Uitwijkmogelijkheden voor schoolverlaters}

De uitwijkmogelijkheden voor schoolverlaters houden verband met de structurele positie van opleidingen op de arbeidsmarkt. Opleidingen omvatten een bepaald curriculum dat kan variëren van een smal en specialistisch vakgebied tot een brede en algemene opleidingsachtergrond. Veranderingen in het curriculum, door bijvoorbeeld een verbreding van de opleiding, leiden tot een betere toegankelijkheid bij verschillende beroepen. Door deze verbreding van het beroependomein wordt de kwetsbaarheid van een opleiding verminderd en daarmee mogelijk ook de conjunctuurgevoeligheid. Daarnaast is er bij werkgevers ook behoefte is aan specifiek opgeleid personeel. Hierdoor kan het wenselijk zijn dat onderwijsinstellingen tevens specialistische opleidingen aanbieden.

Indien de uitwijkmogelijkheden van schoolverlaters bekeken worden, zou het onderwijsbeleid de structurele positie van opleidingen kunnen aanpassen aan de actuele arbeidsmarktsituatie voor schoolverlaters van deze opleidingen. Echter, het is niet de bedoeling dat elk jaar het curriculum van de opleidingen wordt aangepast. Derhalve dient overwogen te worden bij het bepalen van een bepaald curriculum in hoeverre de vraag naar gediplomeerden stabiel is. Hierbij dient een afweging gemaakt te worden van aan de ene kant de voordelen van een specialisme tegen aan de andere kant de risico's van een dergelijk specialisme.

In deze paragraaf wordt een overzicht gegeven van de arbeidsmarktkansen voor de schoolverlaters van de onderscheiden opleidingstypen op VMBO- en MBO-niveau op de Gelderse arbeidsmarkt aan de hand van toekomstige arbeidsmarktperspectieven en de uitwijkmogelijkheden op de arbeidsmarkt. ${ }^{24}$ Het arbeidsmarktperspectief op de middellange termijn van een bepaalde opleiding geeft de mogelijkheden voor nieuwkomers aan. Op basis van de verwachte ontwikkelingen aan de vraag- en aanbodzijde gedurende de komende vijf jaar worden de mogelijkheden voor nieuwkomers om een passende baan te vinden aan de hand van hun opleidingsachtergrond in kaart gebracht.

De mate waarin schoolverlaters afhankelijk zijn van de werkgelegenheidperspectieven van een bepaalde beroepsgroep is een risico-indicator op de arbeidsmarkt. Dit risico is vooral groot bij opleidingen die specifiek gericht zijn op functies in een bepaalde vakdeelmarkt. Een voorbeeld van een specialistische vakdeelmarkt is de arbeidsmarkt voor apothekersassistenten. Gediplomeerde apothekersassistenten zijn namelijk specifiek opgeleid en hun expertise is derhalve in vrijwel geen enkele andere beroepsgroep vereist dan wel gewenst. Derhalve zal deze groep schoolverlaters, wanneer het werkgelegenheidsperspectief minder gunstig is, betrekkelijk moeilijk kunnen uitwijken naar beroepen waarvoor de

24. De indicatoren voor de uitwijkmogelijkheden van werkzoekenden met een bepaalde opleiding zijn gebaseerd op landelijke gegevens. De opleidingsstructuur van de werkgelegenheid is uiteraard wel regio-specifiek. Zie voor de uitleg over de indicatoren voor de uitwijk- en substitutiemogelijkheden de Verklarende woordenlijst, en ook bijv. F. Cörvers c.s. (2002), Methodiek arbeidsmarktprognoses en -indicatoren 2001-2006, ROAW-2002/4, Maastricht. 
werkgelegenheidsontwikkeling gunstiger is. Degenen die daarentegen een opleiding hebben gevolgd waarmee men in diverse beroepsgroepen aan de slag kan, kunnen gemakkelijker uitwijken naar beroepen waarvoor de werkgelegenheidsontwikkeling gunstiger is. In dit geval is er sprake van risicospreiding. Het volgen van een brede opleiding is overigens niet in alle gevallen positief voor de ontwikkelingen op de arbeidsmarkt. Indien er sprake is van veel uitwijkmogelijkheden impliceert dit immers ook dat de schoolverlaters meer concurrentie ondervinden van andere opleidingstypen. Tevens kan een verbreding van de opleiding ten koste gaan van de specialisatie waardoor de productiviteit, c.q. de directe inzetbaarheid van de schoolverlaters, geringer wordt.

Tabel 4.5 laat zien hoe groot de uitwijkmogelijkheden naar de verschillende beroepen zijn in Gelderland. Uit de tabel blijkt dat $26 \%$ van de Gelderse werkenden een opleidingsachtergrond heeft die hen slechts geringe uitwijkmogelijkheden biedt. Echter, ruim $40 \%$ van de werkenden blijken in een relatief breed scala aan beroepen emplooi te kunnen vinden. Tevens laat tabel 4.5 zien dat er aanzienlijke verschillen zijn tussen de opleidingssectoren. Vooral de lager opgeleiden blijken relatief veel uitwijkmogelijkheden te bezitten. De hoger opgeleiden zijn daarentegen min of meer gelijk verdeeld over de beroepsgroepen met lage, gemiddelde en hoge uitwijkmogelijkheden.

Tabel 4.5

Uitwijkmogelijkheden naar verschillende beroepsgroepen (in procenten) per opleidingsniveau in Gelderland, gemiddelde 2000-2001

\begin{tabular}{lccc}
\hline Opleidingsniveau & \multicolumn{2}{c}{ Typering uitwijkmogelijkheden } \\
& $\begin{array}{c}\text { Gemiddeld } \\
\%\end{array}$ & $\begin{array}{c}\text { (Erg) hoog } \\
\%\end{array}$ \\
& & 19 & 69 \\
Basisonderwijs en VMBO & 26 & 50 & 24 \\
HAVO, VWO en MBO & 34 & 32 & 34 \\
HBO en WO & 26 & 33 & 41 \\
Totaal & & & \\
\hline
\end{tabular}

Bron: CBS/ROA

Zoals aangegeven in paragraaf 4.2 en 4.3 geeft het toekomstige arbeidsmarktperspectief een indicatie van de kansen voor nieuwkomers op de arbeidsmarkt op een passende baan. De uitwijkmogelijkheden van de nieuwkomers geven aan in hoeverre de keuze voor een opleiding gepaard gaat met een arbeidsmarktrisico dat de arbeidsmarktkansen zou kunnen ondermijnen. Dit betekent dat indien een goed arbeidsmarktperspectief gepaard gaat met een laag arbeidsmarktrisico (i.e. grote uitwijkmogelijkheden) het betreffende opleidingstype de schoolverlaters een structureel sterke positie geeft op de arbeidsmarkt. De opleidingstypen met de meeste en minste uitwijkmogelijkheden naar verschillende beroepsgroepen voor schoolverlaters worden weergegeven in het bijgaande schema. 


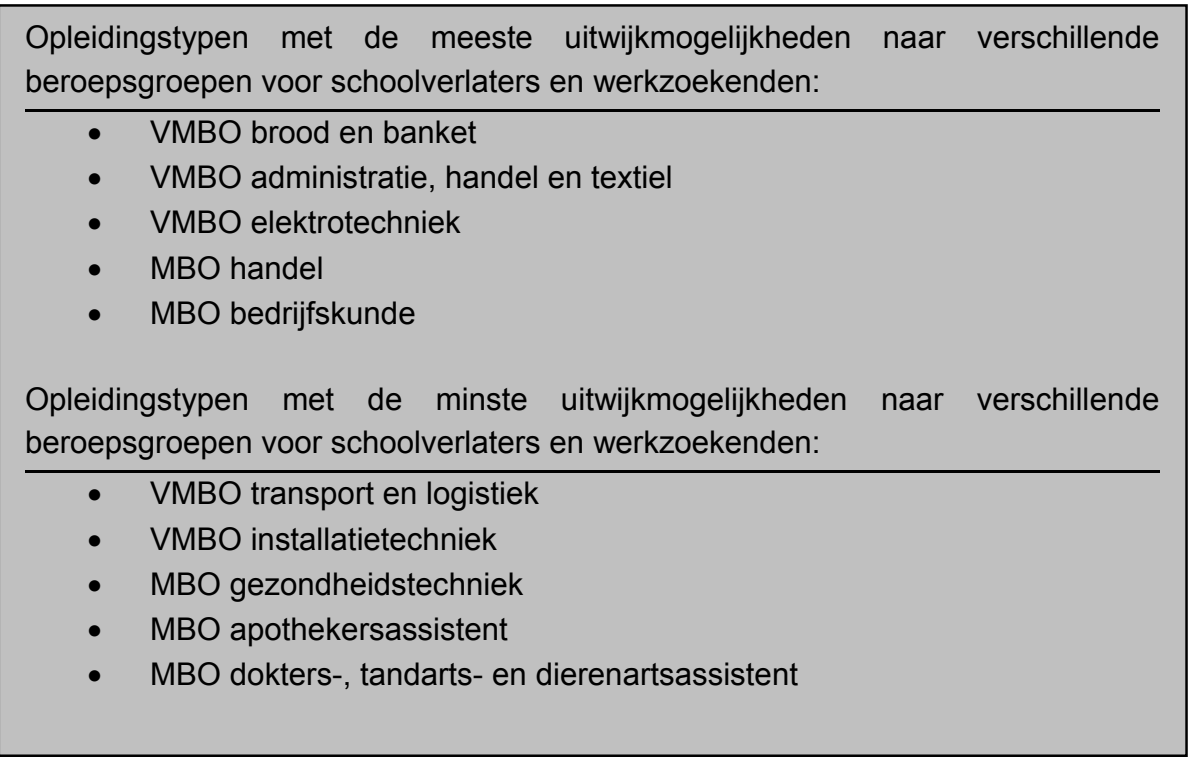

De opleidingstypen met de meeste uitwijkmogelijkheden zijn voornamelijk opleidingen in economische richtingen. Blijkbaar hebben schoolverlaters en werkzoekenden met een dergelijke opleidingsachtergrond een breed curriculum waardoor ze breed inzetbaar zijn. Doordat de arbeidsmarkt in heel verschillende beroepen gekenmerkt wordt door een tekort aan personeel, kunnen voor een deel schoolverlaters met een economische opleidingsachtergrond ingezet worden, eventueel na enige bijscholing, om deze tekorten op te lossen.

De opleidingstypen met de minste uitwijkmogelijkheden naar verschillende beroepsgroepen leiden voornamelijk jongeren op voor een vakdeelmarkt. Dit houdt in dat bijvoorbeeld afgestudeerde apothekers- dokters-, tandarts- en dierenartsassistenten nauwelijks concurrentie ondervinden van schoolverlaters met een andere opleidingsachtergrond. Afgestudeerde apothekers-, dokters-, tandarts- en dierenartsassistenten komen dan ook niet vaak terecht in andere beroepen of branches. ${ }^{25} \mathrm{Er}$ zijn derhalve weinig uitwijkmogelijkheden voor MBO apothekers-, dokters-, tandartsen dierenartsassistenten, maar omdat voor de middellange termijn gunstige arbeidsmarktperspectieven worden verwacht voor schoolverlaters met een dergelijke opleidingsachtergrond is dat niet problematisch.

Uit paragraaf $4.2 \mathrm{komt}$ naar voren dat schoolverlaters met opleidingsachtergrond VMBO administratie, handel en textiel slechte arbeidsmarktperspectieven kunnen verwachten voor zowel de korte als de lange termijn. Dit opleidingstype wordt tevens gekenmerkt door grote uitwijkmogelijkheden voor schoolverlaters. Hoewel dit zou kunnen betekenen dat schoolverlaters op een groot spectrum aan de onderkant van

25. J. Sanders, R. de Vries en M. Wolbers, (2003). Apothekersassistenten van school naar werk, ROA-R-2003/**, Maastricht, binnenkort te verschijnen. 
de arbeidsmarkt inzetbaar zijn, kunnen de slechte arbeidsmarktperspectieven ook een gevolg zijn van deze brede inzetbaarheid.

\subsection{Substitutiemogelijkheden voor werkgevers}

In de voorgaande paragraaf is aandacht besteed aan de krapte op de arbeidsmarkt voor schoolverlaters met een algemene of specifieke opleidingsachtergrond. Deze krapte op de arbeidsmarkt zal zijn weerslag hebben op de verschillende beroepsgroepen. Indien voor een bepaald beroep kennis en vaardigheden vereist zijn die met name aanwezig zijn bij mensen waarvoor geldt dat hun opleidingsachtergrond gekenmerkt wordt door tekorten, zullen werkgevers problemen ondervinden bij het vinden van geschikt personeel. Indien tevens geldt dat zeer beroepsspecifieke kennis en vaardigheden vereist zijn, zullen de knelpunten in de personeelsvoorziening bijzonder moeilijk op te lossen zijn aangezien er weinig alternatieven voorhanden zijn. Hierbij wordt met alternatieven bedoeld schoolverlaters en werkzoekenden met een bepaalde opleidingsachtergrond die niet direct aansluit op het beroep, maar waarbij wel door enige bijscholing de vereiste kennis en vaardigheden kunnen worden opgedaan. Indien een werkgever personeel nodig heeft voor beroepen waarvoor algemene competenties in belangrijke mate vereist zijn, kan de werkgever vaak wel schoolverlaters van alternatieve opleidingen inzetten om de knelpunten in de personeelsvoorziening op te lossen.

De substitutiemogelijkheden voor de werkgevers kunnen in verband worden gebracht met de verwachte knelpunten in de personeelsvoorziening zoals deze gepresenteerd werden in paragraaf 4.3. De substitutiemogelijkheden voor werkgevers geven aan in hoeverre werkgevers arbeidskrachten kunnen aantrekken met uiteenlopende opleidingsachtergronden. Indien werkgevers afhankelijk zijn van het arbeidsaanbod van een bepaald opleidingstype zullen de substitutiemogelijkheden beperkt zijn. De substitutiemogelijkheden voor de werkgevers kunnen bepaald worden aan de hand van een spreidingsindex van opleidingen over de beroepsgroepen.

Tabel 4.6

Substitutiemogelijkheden naar beroepsgroepen waarvoor geen, enige en grote knelpunten worden verwacht in de personeelsvoorziening (in procenten) voor Gelderland, gemiddelde 2000-2001

\begin{tabular}{lrrr}
\hline & $\begin{array}{r}\text { (Vrijwel) geen } \\
\text { knelpunten }\end{array}$ & $\begin{array}{r}\text { Enige knel- } \\
\text { punten }\end{array}$ & $\begin{array}{c}\text { (Zeer) grote } \\
\text { knel-punten }\end{array}$ \\
\hline $\begin{array}{l}\text { Percentage werkenden waarvoor (erg) kleine } \\
\text { substitutiemogelijkheden }\end{array}$ & 15 & 15 & 23 \\
$\begin{array}{l}\text { Percentage werkenden waarvoor gemiddelde } \\
\text { substitutiemogelijkheden }\end{array}$ & 46 & 55 & 23 \\
$\begin{array}{l}\text { Percentage werkenden waarvoor (erg) grote } \\
\text { substitutiemogelijkheden }\end{array}$ & 39 & 30 & 54 \\
Totaal & 100 & 100 & 100 \\
\hline Bron: CBS/ROA & & &
\end{tabular}


Tabel 4.6 laat zien dat er nauwelijks verschil is tussen de verdeling van werkenden naar substitutiemogelijkheden voor beroepsgroepen waarvoor (vrijwel) geen knelpunten verwacht worden in de personeelsvoorziening en beroepsgroepen waarvoor slechts enige knelpunten verwacht worden. Voor beroepsgroepen met (zeer) grote knelpunten hebben werkgevers voor $23 \%$ van de werkenden (erg) kleine substitutiemogelijkheden. De beperkte substitutiemogelijkheden voor deze werkenden kunnen de oorzaak zijn van het moeilijk kunnen oplossen van de knelpunten in de personeelsvoorziening. Voor werkgevers kan het van belang zijn om na te gaan of schoolverlaters van alternatieve opleidingen toch niet ingezet kunnen worden in sommige van deze beroepsgroepen.

Verder blijkt uit tabel 4.6 dat werkgevers voor $54 \%$ van de werkenden in beroepsklassen met (zeer) grote knelpunten in de personeelsvoorziening tevens (zeer) grote substitutiemogelijkheden hebben. Aangezien de knelpunten voor deze beroepsklassen ondanks de grote substitutiemogelijkheden toch aanzienlijk zijn, impliceert dat dat er over een breed spectrum van de arbeidsmarkt onvoldoende aanbod is van schoolverlaters van deze opleidingstypen binnen deze beroepsklassen.

Tabel 4.7 laat zien hoe groot de substitutiemogelijkheden tussen mensen met uiteenlopende opleidingsachtergronden zijn voor alle beroepsklassen in Gelderland. Uit de tabel blijkt dat bijna $20 \%$ van de werkenden binnen beroepsklassen lage substitutiemogelijkheden hebben in Gelderland. Ruim $40 \%$ van de werkenden hebben echter hoge substitutiemogelijkheden. Werkgevers in Gelderland beschikken in $43 \%$ van werkenden binnen beroepsklassen over de mogelijkheid arbeidskrachten aan te nemen met uiteenlopende opleidingsachtergronden. Tabel 4.7 laat tevens zien dat de substitutiemogelijkheden tussen mensen met uiteenlopende opleidingsachtergrond in bijvoorbeeld de Pedagogische beroepen gering zijn. Dit geldt ook voor de Culturele, Medische en paramedische beroepen. Voor deze beroepsklassen geldt dat zeer beroepsspecifieke kennis en vaardigheden vereist zijn. De Transportberoepen daarentegen bevatten doorgaans hoge tot erg hoge substitutiemogelijkheden. Dit geldt tevens voor de Economisch-administratieve en de Informaticaberoepen. Vooral bij de Transportberoepen en Economisch-administratieve beroepen zijn doorgaans algemene competenties vereist. Hierdoor kunnen werkgevers schoolverlaters en werkzoekenden van alternatieve opleidingen gebruiken bij het aantrekken van arbeidskrachten om de knelpunten in de personeelsvoorziening op te lossen. 
Tabel 4.7

Substitutiemogelijkheden tussen mensen met uiteenlopende opleidingsachtergronden per beroepsklasse (in procenten) in Gelderland, gemiddelde 2000-2001

Beroepsklasse

Typering substitutiemogelijkheden

$\begin{array}{ccc}\text { (Erg) laag } & \text { Gemiddeld } & (\text { Erg) hoog } \\ \% & \% & \%\end{array}$

Pedagogische beroepen

$\begin{array}{rrr}75 & 22 & 3 \\ 60 & 21 & 19 \\ 5 & 88 & 7 \\ 24 & 51 & 25 \\ 0 & 8 & 92 \\ 53 & 45 & 2 \\ 6 & 18 & 76 \\ 3 & 36 & 61 \\ 18 & 42 & 40 \\ 8 & 61 & 31 \\ 47 & 10 & 43\end{array}$

Agrarische beroepen

Technische en industrie beroepen

Transportberoepen

Medische en paramedische beroepen

Economisch-administratieve beroepen

Informaticaberoepen

Sociaal-culturele beroepen

Verzorgende en dienstverlenende beroepen

Openbare orde- en veiligheidsberoepen

19

38

Bron: CBS/ROA

De beroepsklassen in tabel 4.7 kunnen onderverdeeld worden in 127 beroepsgroepen. De beroepsgroepen met de meeste en minste substitutiemogelijkheden voor werkgevers worden weergegeven in het bijgaande schema. Voor de beroepsgroepen met de meeste substitutiemogelijkheden voor werkgevers zijn de toekomstige knelpunten in de personeelsvoorziening mogelijkerwijs te verlichten door de inzet van personeel met een alternatieve opleidingsachtergrond.

Beroepsgroepen met de meeste substitutiemogelijkheden voor werkgevers:

- Bibliotheekassistenten

- Conciërges

- Monteurs

- Procesoperators

- Commercieel medewerkers

Beroepsgroepen met de minste substitutiemogelijkheden voor werkgevers:

- Bouwvakkers

- Elektromonteurs

- Verplegenden en doktersassistenten

- Ziekenverzorgenden

- Politieagenten en beveiligingsemployés 
Uit paragraaf 4.3 is gebleken dat de werkgevers op de korte termijn relatief veel rekruteringsproblemen kunnen verwachten bij het werven van onder andere elektromonteurs en ziekenverzorgenden. Dit zijn beroepsgroepen waarbij er vrijwel geen substitutiemogelijkheden voor werkgevers zijn waardoor de werkgevers geheel afhankelijk zijn van het arbeidsaanbod.

Op de middellange termijn kunnen werkgevers rekruteringsproblemen verwachten bij het aantrekken van onder andere conciërges, procesoperators en commercieel medewerkers. Deze beroepsgroepen worden echter gekenmerkt door veel substitutiemogelijkheden voor werkgevers. Werkgevers kunnen besluiten schoolverlaters van andere opleidingstypen dan de opleidingstypen van de eerste voorkeur aan te nemen, eventueel met enig productiviteitsverlies. Een voorwaarde is echter dat er van de andere opleidingstypen voldoende aanbod kan worden aangetrokken. Hierdoor kunnen de rekruteringsproblemen op de middellange termijn wellicht verminderd worden voor de werkgevers in Gelderland. 


\section{Pendel tussen Gelderland en omliggende gebieden}

Een toename van de dynamiek tussen regio's in de vorm van grotere pendelstromen kan de arbeidsmarktdiscrepanties binnen regio's doen verminderen. Vooral in het geval specifieke opleidingsvereisten en competenties op een relatief klein segment van de arbeidsmarkt is het voor werkgevers en werkzoekenden van belang om de horizon in geografische zin te verbreden. Geografische arbeidsmobiliteit is dan welhaast een randvoorwaarde om vraag en aanbod dichter bij elkaar te brengen.

Ruim 100.000 personen reizen vanuit Gelderland naar hun werk in een andere provincie. Deze uitgaande pendel overtreft de inkomende pendel met bijna 30.000 personen. De provincie Gelderland heeft derhalve een negatief pendelsaldo met de rest van Nederland. Het blijkt dat in de noord-zuid richting de inkomende pendel over het algemeen groter dan de uitgaande pendel. Er gaan dus meer mensen vanuit Overijssel, Noord-Brabant en Limburg in Gelderland werken dan omgekeerd. Daarentegen is er een grotere uitgaande pendel in de westelijke richting dan omgekeerd. Dit betekent dat mensen die in Gelderland wonen de neiging hebben naar het westen te gaan om te werken, met name in de provincies Utrecht, Flevoland, Noord-Holland en Zuid-Holland.

Over het algemeen zijn de pendelaars beter opgeleid en verdienen ze meer dan de blijvers. Bovendien pendelen vrouwen relatief minder dan mannen, vooral wanneer ze kinderen hebben. Pendelaars zijn ten opzichte van de 'blijvers' vaak tussen de 30 en 40 jaar oud. De Gelderse pendelaars overbruggen gemiddeld iets kleiner afstanden dan de landelijke pendelaars, waardoor ook hun reistijd gemiddeld iets korter is. Dit hangt waarschijnlijk voor een deel samen met iets hogere gemiddelde opleidingsniveau van de landelijke ten opzichte van de Gelderse pendelaars.

Om deze pendelstromen in verband te brengen met de knelpunten op de Gelderse arbeidsmarkt zullen de achtergrondkenmerken van de pendelaars in kaart gebracht worden. Zo blijken veel mensen die vanuit Gelderland pendelen naar Utrecht te werken in de Economisch-administratieve beroepen. Voor deze beroepen worden grote knelpunten in de personeelsvoorziening verwacht op de middellange termijn in Gelderland. Door een afname van de uitgaande pendel en een toename van de inkomende pendel kunnen de toekomstige knelpunten in de personeelsvoorziening in Gelderland verkleind worden. Deze vereiste aanpassingen in de pendelstromen zijn echter aanzienlijk. Derhalve kunnen deze aanpassingen slechts in beperkte mate een oplossing bieden voor het verlichten van knelpunten op de Gelderse arbeidsmarkt, temeer omdat voor de rest van Nederland ook grote knelpunten in de personeelsvoorziening verwacht worden voor de middellange termijn. Voor sommige beroepen, bijvoorbeeld voor de Technische en industrieberoepen zijn de vereiste aanpassingen in de pendelstromen veel kleiner. Door de uitgaande pendel in deze beroepsklasse met $5 \%$ te laten afnemen of de inkomende pendel met $6 \%$ te laten toenemen kunnen de toekomstige knelpunten in de personeelsvoorziening in 
Gelderland zelfs geheel worden opgelost. Toch zullen deze aanpassingen nog steeds aanzienlijke inspanningen van Gelderse overheden en werkgevers vereisen.

Naast het stimuleren van de binnenlandse pendelstromen kan de grenspendel met Duitsland ook zorgen voor een verkleining van de mismatch tussen vraag en aanbod op specifieke segmenten van de Gelderse arbeidsmarkt. Het blijkt dat op het gebied van taal, sociale zekerheid en belastingen bestaat nog altijd een aantal barrières bestaat waardoor de grenspendel relatief gering is. Ruim $15 \%$ van de pendelstroom tussen Duitsland en Nederland heeft betrekking op de provincie Gelderland. Het pendelsaldo tussen Gelderland en Duitsland is negatief en omvat in 2001 nog geen 1.000 personen. Het negatieve pendelsaldo met Duitsland is echter mede door de grote krapte op de Nederlandse arbeidsmarkt gedurende de laatste jaren aanzienlijk afgenomen.

\subsection{Inleiding}

Bij het vinden van een nieuwe of andere baan moeten werkzoekenden verschillende afwegingen maken. De baanzoekduur wordt daarbij beïnvloed door de vraag-aanbod verhoudingen, maar ook door kennis en vaardigheden van de werkzoekenden en de eisen die door hen gesteld worden aan de nieuwe functie, de werkgever en de arbeidsvoorwaarden. Daarbij speelt ook de geografische mobiliteit van de werkzoekende, dat wil zeggen de bereidheid om te verhuizen of te pendelen, een belangrijke rol. Naarmate de arbeidsmarkt ruimer is en de aanbodoverschotten groter zijn, kunnen door hem of haar minder hoge eisen worden gesteld, en zal een eventuele verhuizing of langere reistijd voor lief moeten worden genomen bij het vinden van een nieuwe baan. Werkzoekenden kunnen bovendien de kans op een baan vergroten door zich voor een lager loon op de arbeidsmarkt aan te bieden. Dit kan samengaan met de bereidheid om een baan te accepteren die onder het behaalde opleidingsniveau ligt of die buiten de vakrichting valt waarvoor men gestudeerd heeft. Verder kunnen de bereidheid tot het accepteren van een tijdelijke baan of een baan in deeltijd het vinden van werk aanzienlijk bespoedigen. De werkzoekende zal alle genoemde aspecten, inclusief de geografische mobiliteit, meewegen bij de beslissing over de aanvaarding van een nieuwe baan.

In dit hoofdstuk zal worden onderzocht in welke mate de Gelderse beroepsbevolking genegen is om naar het werk te reizen. Het referentiekader hierbij is het gemiddelde woon-werk verkeer in Nederland. Het zal onder meer blijken dat de achtergrondkenmerken, zoals leeftijd, geslacht en opleiding een belangrijke rol bij de pendelbereidheid spelen. In het kader van dit rapport is het met name interessant om na te gaan in welke mate veranderingen van de pendelstromen tussen Gelderland en de omliggende gebieden kunnen bijdragen aan een vermindering van de in hoofdstuk 4 geconstateerde discrepanties tussen vraag en aanbod op de Gelderse arbeidsmarkt. Overigens hebben ook de in dit hoofdstuk weergegeven actuele pendelstromen zich ontwikkeld mede op basis van de recente vraag-aanbod verhoudingen op de verschillende arbeidsmarktsegmenten van Gelderland en de aangrenzende provincies. 
Zowel migratie als pendel (woon-werk verkeer) kunnen zorgen voor een vermindering van de mismatch tussen vraag en aanbod op regionale arbeidsmarkten. Vooral in het geval specifieke opleidingsvereisten en competenties op een relatief klein segment van de arbeidsmarkt is het voor werkgevers en werkzoekenden van belang om de horizon in geografische zin te verbreden. Geografische mobiliteit is dan welhaast een randvoorwaarde om vraag en aanbod dichter bij elkaar te brengen. Een toename van de dynamiek tussen regio's in de vorm van grotere pendelstromen kan de arbeidsmarktdiscrepanties binnen regio's doen verminderen.

Het is derhalve van belang de huidige pendelstromen, dat wil zeggen inkomende en uitgaande pendel, voor de provincie Gelderland in kaart te brengen. De belangrijkste pendelstromen zullen plaatsvinden tussen Gelderland en de omliggende provincies, maar ook tussen Gelderland en Duitsland. Het is te eenvoudig te veronderstellen dat door het stimuleren van de pendelbereidheid de regionale verschillen in discrepanties tussen vraag en aanbod geheel verdwijnen. Dit zou uiteindelijk betekenen dat de arbeidsmarktsituatie niet meer wezenlijk verschilt tussen regio's, maar dat overal min of meer dezelfde tekorten en overschotten op de arbeidsmarkt bestaan. De feitelijke pendelstromen zullen echter beperkt worden door de daaraan verbonden kosten. Dit geldt zowel voor individuen als voor overheden. Individuen moeten ten gevolge van pendel kosten maken voor het overbruggen van een bepaalde reisafstand. Bovendien zou de reistijd kunnen worden gerekend tot de uren die mee besteed worden aan het werk, waardoor het feitelijk netto uurloon lager uitvalt. Daarnaast zou het vinden van een baan die verder van de woonplaats gelegen is, hogere zoekkosten met zich mee kunnen brengen. Deze zijn te beschouwen als een eenmalige investering om de kans op het vinden van een baan te vergroten. Overheden zouden kunnen investeren in een betere infrastructuur, i.e. het wegennet en het openbaar vervoer, om de reistijd van individuen te bekorten. Daarnaast zouden zij de verschillen in de arbeidsmarktsituatie tussen regio's kunnen verkleinen door het compenseren van de reiskosten, het verstrekken van regionale arbeidsmarktinformatie, en het stimuleren van de interregionale arbeidsbemiddeling.

In paragraaf 5.2 zullen de regionale pendelstromen tussen provincie Gelderland en de andere provincies van Nederland besproken worden. Om deze pendelstromen in verband te kunnen brengen met de knelpunten op de Gelderse arbeidsmarkt is het wenselijk de achtergrondkenmerken van de pendelaars in kaart te brengen. In paragraaf 5.3 zullen deze achtergrondkenmerken van de Gelderse pendelaars vergeleken worden met die van de Nederlandse pendelaars. In paragraaf 5.4 zal worden bekeken in welke mate de verwachte toekomstige Nederlandse arbeidsmarktsituatie afwijkt van de Gelderse, en of veranderingen in de pendelstromen tussen Gelderland en de andere provincies van Nederland de verwachte knelpunten op de Gelderse arbeidsmarkt kunnen verlichten. Naast de pendel binnen Nederland kunnen de pendelstromen met Duitsland van belang zijn. In paragraaf 5.5 zal deze internationale pendelstroom aan bod komen. 


\subsection{Omvang van de inkomende en uitgaande pendelstromen}

Inwoners van de provincie Gelderland en de omliggende provincies zijn voor wat betreft hun werkgelegenheid afhankelijk van een aantal belangrijke werkgelegenheidscentra op een redelijke afstand of reistijd van hun woonplaats. Daarbij maakt het voor individuen meestal weinig uit of de gemeente waar men werkt binnen of buiten Gelderland gelegen is. Dit impliceert dat de regionale arbeidsmarkt niet ophoudt bij de Gelderse provinciegrenzen en dat interprovinciale pendel welhaast vanzelfsprekend is.

Pendelstromen binnen Nederland zijn van belang bij het oplossen van regionale arbeidsmarktproblemen. Indien de ene provincie te kampen heeft met een aanbodoverschot voor een bepaald beroep terwijl in een andere (aangrenzende) provincie een vraagoverschot bestaat voor datzelfde beroep, dan kunnen pendelstromen deze regionale discrepanties verminderen. Aan de hand van gegevens uit het Onderzoek Verplaatsingsgedrag 2001 (OVG) van het CBS worden hier de pendelstromen tussen Gelderland en de andere provincies nader onderzocht. Tabel 5.1 geeft een overzicht van deze pendelstromen. De inkomende pendel is $8,8 \%$ procent van de werkende beroepsbevolking in Gelderland, oftewel ongeveer 73.500 personen. Daartegenover heeft $12,3 \%$ van de Gelderse werkende beroepsbevolking een baan buiten de provincie Gelderland. Dit zijn circa 103.000 werkenden. De uitgaande pendel overtreft de inkomende pendel met bijna 30.000 personen. De provincie Gelderland heeft derhalve een negatief pendelsaldo met de rest van Nederland. Verder blijkt dat de grootste pendelstromen van Gelderland plaatsvinden met de provincies Noord-Brabant, Utrecht en Overijssel.

Tabel 5.1

Inkomende en uitgaande pendelstromen voor de provincie Gelderland als percentage van de werkende beroepsbevolking van Gelderland, 2001

\begin{tabular}{lccc} 
Provincies & $\begin{array}{c}\text { Inkomende pendel } \\
\%\end{array}$ & $\begin{array}{c}\text { Uitgaande pendel } \\
\%\end{array}$ & Pendelsaldo \\
\hline Groningen & 0,1 & 0,2 & - \\
Friesland & 0,1 & 0,1 & 0 \\
Drenthe & 0,1 & 2,2 & - \\
Overijssel & 2,4 & 0,5 & - \\
Flevoland & 0,2 & 4,4 & - \\
Utrecht & 1,8 & 1,7 & - \\
Noord-Holland & 0,5 & 1,3 & - \\
Zuid-Holland & 0,9 & 0,0 & + \\
Zeeland & 0,0 & 1,8 & + \\
Noord-Brabant & 1,9 & 0,3 & + \\
Limburg & 0,7 & 12,3 & - \\
Totaal & 8,8 & & \\
\end{tabular}

Bron: CBS (OVG)

De provincie Gelderland heeft vooral met de provincies Utrecht, Noord-Holland en Zuid-Holland een negatief pendelsaldo. Dit betekent dat veel mensen vanuit de provincie Gelderland naar deze provincies gaan om te werken. Er is sprake van een 78 
positief pendelsaldo met de provincies Noord-Brabant, Overijssel en Limburg. Het blijkt dat in de noord-zuid richting de inkomende pendel over het algemeen groter dan de uitgaande pendel. Er gaan dus meer mensen vanuit Overijssel, NoordBrabant en Limburg in Gelderland werken dan omgekeerd. Daarentegen is er een grotere uitgaande pendel in de westelijke richting dan omgekeerd. Dit betekent dat mensen die in Gelderland wonen de neiging hebben naar het westen te gaan om te werken, met name in de provincies Utrecht, Flevoland, Noord-Holland en ZuidHolland.

Het is voor goed inzicht in de pendelstromen tevens van belang de pendelstromen binnen de provincie Gelderland te onderscheiden. Op basis hiervan kan men de werkgelegenheidscentra in de provincie Gelderland onderscheiden. Deze regio's worden dan gekenmerkt door veel inkomende pendel en kunnen daardoor gezien worden als een aantrekkelijke regionale arbeidsmarkt. Regio's die daarentegen gekenmerkt worden door veel uitgaande pendel bieden blijkbaar relatief minder werkgelegenheid.

Tabel 5.2

Verdeling van Gelderse inkomende en uitgaande pendelstromen naar gemeente, 2001

\begin{tabular}{lccc}
\hline Gemeenten & $\begin{array}{c}\text { Inkome } \\
\%\end{array}$ & $\begin{array}{c}\text { Uitgaande pendel } \\
\%\end{array}$ & $\begin{array}{c}\text { Pendelsaldo } \\
\text { Arnhem }\end{array}$ \\
Nijmegen & 7,7 & 6,7 & + \\
Apeldoorn & 7,1 & 5,8 & + \\
Ede & 5,7 & 4,2 & + \\
Zutphen & 3,8 & 3,1 & + \\
Doetinchem & 2,1 & 2,0 & + \\
Rheden & 2,1 & 2,0 & + \\
Harderwijk & 1,9 & 1,9 & + \\
Barneveld & 1,8 & 1,4 & + \\
Overige & 1,7 & 1,5 & + \\
Totaal (a) & 66,1 & 71,4 & + \\
\end{tabular}

Bron: CBS (OVG)

In tabel 5.2 staan de gemeenten vermeld met de hoogste inkomende en uitgaande pendel. Deze gemeenten hebben blijkbaar een grote aantrekkingskracht op werknemers en veel arbeidsplaatsen. Vooral Arnhem, Nijmegen en Apeldoorn trekken veel werkenden uit andere gemeenten aan. Echter, dit zijn ook de gemeenten met de hoogste uitgaande pendel. Blijkbaar wonen er ook relatief veel mensen in deze steden die er niet werken.

\subsection{Achtergrondkenmerken van de pendelaars}

Mensen maken een keuze uit een groot aanbod van verplaatsingsmogelijkheden om van hun woonlocatie op hun werk te komen. Op deze manier zorgt een toename in de mobiliteit voor een betere aanpassing van vraag en aanbod op regionale 
arbeidsmarkten. Naast deze positieve effecten heeft het keuzegedrag van individuen met betrekking tot de mobiliteit ook negatieve effecten op de leefomgeving. ${ }^{26} \mathrm{De}$ veranderingen die plaatsvinden ten gevolge van een toenemende geografische mobiliteit hebben namelijk direct invloed op de ruimtelijke kwaliteit van regio's. Hierbij kan men denken aan congestie en het verloren gaan van natuur door het aanleggen van infrastructuur.

Om beter zicht te krijgen op de individuele factoren die de pendelbereidheid beïnvloeden is het van belang om de achtergrondkenmerken van pendelaars nader te bekijken. Hierbij gaat het niet alleen om de bedrijfssectoren waarin de pendelaars werkzaam zijn, maar ook om hun opleidingsniveau, inkomen, geslacht en leeftijd.

Tabel 5.3

Het geslacht van de pendelaars en de blijvers van Gelderland en Nederland, 2001

\begin{tabular}{|c|c|c|c|c|c|}
\hline \multirow[t]{2}{*}{ Geslacht } & \multicolumn{3}{|c|}{ Gelderland } & \multicolumn{2}{|c|}{ Nederland } \\
\hline & $\begin{array}{c}\text { Inkomende } \\
\text { pendel } \\
\%\end{array}$ & $\begin{array}{c}\text { Uitgaande } \\
\text { pendel } \\
\%\end{array}$ & $\begin{array}{c}\text { Blijvers } \\
\%\end{array}$ & $\begin{array}{c}\text { Pendelaars } \\
\%\end{array}$ & $\begin{array}{c}\text { Blijvers } \\
\%\end{array}$ \\
\hline Man & 76,2 & 76,3 & 62,8 & 75,2 & 62,1 \\
\hline Vrouw & 23,8 & 23,7 & 37,2 & 24,8 & 37,9 \\
\hline Totaal & 100 & 100 & 100 & 100 & 100 \\
\hline
\end{tabular}

Bron: CBS (OVG)

Tabel 5.3 laat zien dat vooral mannen pendelen en dat vrouwen meestal in de provincie werken waar ze wonen. Dit geldt voor zowel Gelderse als Nederlandse pendelaars. Een reden voor dit verschil in pendelgedrag tussen mannen en vrouwen zou kunnen zijn dat vrouwen meer taken met betrekking tot de verzorging van hun kinderen op zich nemen vergeleken met mannen. Tabel 5.4 geeft daarom een overzicht van het pendelgedrag in verhouding tot de gezinssamenstelling uitgesplitst naar geslacht. Uit deze tabel blijkt dat $67 \%$ van de mannelijke pendelaars geen kinderen hebben. Vrouwelijke pendelaars daarentegen hebben in verhouding veel minder vaak kinderen, namelijk $12,5 \%$ van de vrouwelijke inkomende pendelaars en $21,5 \%$ van de vrouwelijke uitgaande pendelaars. Het verschil tussen de pendelaars en de blijvers voor zowel Gelderland als Nederland is echter niet groot.

26. Ministerie van Volksgezondheid, Welzijn en Sport (2000), Nationaal Verkeers- en Vervoersplan (NVVP), Den Haag. 
Tabel 5.4

De gezinssamenstelling van pendelaars en blijvers van Gelderland en Nederland, 2001

\begin{tabular}{llccccc}
\hline Kinderen & \multicolumn{3}{c}{} & \multicolumn{3}{c}{ Nederland } \\
& & $\begin{array}{c}\text { Gelderland } \\
\text { Inkomende } \\
\text { pendel } \\
\%\end{array}$ & $\begin{array}{c}\text { Uitgaande } \\
\text { pendel } \\
\%\end{array}$ & $\begin{array}{c}\text { Blijvers } \\
\%\end{array}$ & $\begin{array}{c}\text { Pendelaars } \\
\text { Blijvers }\end{array}$ & $\%$ \\
\hline \multirow{2}{*}{ Man } & Met kinderen & 32,9 & 32,5 & 31,2 & 30,8 & 29,9 \\
& Zonder kinderen & 67,1 & 67,5 & 68,8 & 69,2 & 70,1 \\
\hline \multirow{2}{*}{ Vrouw } & Met kinderen & 12,5 & 21,5 & 21,1 & 19,8 & 22,4 \\
& Zonder kinderen & 87,5 & 78,5 & 78,9 & 80,2 & 77,6
\end{tabular}

Bron: CBS (OVG)

Tabel 5.5

De leeftijd van pendelaars en blijvers van Gelderland en Nederland, 2001

\begin{tabular}{|c|c|c|c|c|c|}
\hline \multirow[t]{2}{*}{ Leeftijdsklassen } & \multicolumn{3}{|c|}{ Gelderland } & \multicolumn{2}{|c|}{ Nederland } \\
\hline & $\begin{array}{l}\text { Inkomende } \\
\text { pendel }\end{array}$ & $\begin{array}{l}\text { Uitgaande } \\
\text { pendel }\end{array}$ & Blijvers & Pendelaars & Blijvers \\
\hline 15-19 jaar & 1,9 & 2,7 & 5,2 & 1,8 & 4,5 \\
\hline 20-24 jaar & 6,5 & 7,3 & 8,7 & 7,0 & 8,3 \\
\hline 25-29 jaar & 13,9 & 13,2 & 11,0 & 13,7 & 11,6 \\
\hline 30-34 jaar & 16,0 & 15,7 & 12,4 & 15,8 & 13,2 \\
\hline 35-39 jaar & 17,4 & 15,9 & 13,5 & 14,6 & 13,5 \\
\hline $40-45$ jaar & 12,2 & 11,9 & 14,1 & 13,0 & 13,7 \\
\hline 45-49 jaar & 10,2 & 14,8 & 13,1 & 12,8 & 13,2 \\
\hline 50-54 jaar & 9,8 & 11,6 & 12,7 & 11,3 & 12,5 \\
\hline 55-59 jaar & 9,4 & 5,5 & 7,2 & 7,6 & 7,2 \\
\hline 60-64 jaar & 2,8 & 1,4 & 2,0 & 2,4 & 2,2 \\
\hline Totaal & 100 & 100 & 100 & 100 & 100 \\
\hline
\end{tabular}

Bron: CBS (OVG)

Tabel 5.5 laat vervolgens zien dat de pendelaars doorgaans een hogere leeftijd hebben vergeleken met de mensen die werken in de provincie waar ze wonen. Zo blijken de pendelaars van Gelderland vaak tussen de 30 en 40 jaar te zijn en dit komt overeen met de leeftijd van de landelijke pendelaars. Zo blijkt dat ruim $33 \%$ van de inkomende pendel van Gelderland tussen de 30 en 40 jaar te zijn. Bij de mensen die vanuit Gelderland elders gaan werken (uitgaande pendel) valt op dat bijna $15 \%$ een leeftijd tussen 45 en 49 jaar heeft, terwijl de inkomende pendel van deze leeftijdsgroep slechts $10 \%$ bedraagt.

Uit tabel 5.6 blijkt dat de pendelaars doorgaans een hoger opleidingsniveau hebben vergeleken met de mensen die in dezelfde provincie werken waar ze wonen, de blijvers. Zo blijkt gemiddeld $38,3 \%$ van de pendelaars van Gelderland een HBO- of WO-opleiding te hebben afgerond, terwijl slechts $26,9 \%$ van de mensen die in Gelderland wonen en werken dit opleidingsniveau hebben. Overigens is landelijk dit 
verschil nog groter, namelijk $43,5 \%$ tegenover $28,8 \%$ van de blijvers. De lager opgeleiden daarentegen (basisonderwijs en VMBO) werken vaak in de provincie waar ze wonen. Zo blijkt gemiddeld $26 \%$ van de Gelderse pendelaars laag opgeleid te zijn terwijl ruim $37 \%$ van de mensen die wonen in de provincie waar ze werken dit opleidingsniveau hebben.

Tabel 5.6

Het opleidingsniveau van pendelaars en blijvers van Gelderland en Nederland, 2001

\begin{tabular}{|c|c|c|c|c|c|}
\hline \multirow[t]{2}{*}{ Opleidingsniveau } & \multicolumn{3}{|c|}{ Gelderland } & \multicolumn{2}{|c|}{ Nederland } \\
\hline & $\begin{array}{c}\text { Inkomende } \\
\text { pendel } \\
\%\end{array}$ & $\begin{array}{c}\text { Uitgaande } \\
\text { pendel } \\
\%\end{array}$ & $\begin{array}{c}\text { Blijvers } \\
\%\end{array}$ & $\begin{array}{c}\text { Pendelaars } \\
\%\end{array}$ & $\begin{array}{c}\text { Blijvers } \\
\%\end{array}$ \\
\hline Basisonderwijs & 1,9 & 3,1 & 5,6 & 2,6 & 4,9 \\
\hline VMBO & 24,4 & 22,9 & 31,6 & 20,8 & 29,4 \\
\hline MBO/HAVO/VWO & 35,3 & 34,2 & 35,9 & 33,1 & 36,9 \\
\hline HBO/WO & 38,3 & 39,8 & 26,9 & 43,5 & 28,8 \\
\hline Totaal & 100 & 100 & 100 & 100 & 100 \\
\hline
\end{tabular}

Bron: CBS (OVG)

Tabel 5.7 laat zien dat de pendelaars van Gelderland vaak tussen de $€ 22.500$ en $€$ 30.000 bruto per jaar verdienen, terwijl de Nederlandse pendelaars vaak in de hoogste categorie zitten, namelijk meer dan $€$ 30.000. Dit komt uiteraard overeen met het opleidingsniveau van de pendelaars. Gemiddeld beschikken pendelaars binnen heel Nederland namelijk over een hoger opleidingsniveau dan de Gelderse pendelaars, waardoor ook het gemiddelde inkomen hoger is. Tevens komt duidelijk uit tabel 5.7 naar voren dat mensen die in dezelfde provincie werken waar ze wonen aanmerkelijk minder verdienen dan pendelaars. Zo blijkt dat gemiddeld ruim $15 \%$ van de pendelaars minder dan $€ 15.000$ te verdienen per jaar terwijl $32 \%$ van de mensen die in dezelfde provincie wonen waar ze werken dit bedrag aan inkomen ontvangen.

Tabel 5.7

Het inkomen van pendelaars en blijvers van Gelderland en Nederland, 2001

\begin{tabular}{|c|c|c|c|c|c|}
\hline \multirow[t]{3}{*}{ Inkomen } & \multicolumn{3}{|c|}{ Gelderland } & \multicolumn{2}{|c|}{ Nederland } \\
\hline & Inkomende & Uitgaande & Blijvers & Pendela & Blijvers \\
\hline & $\%$ & $\%$ & $\%$ & $\%$ & $\%$ \\
\hline Geen inkomen & 0,8 & 1,4 & 2,5 & 1,0 & 2,0 \\
\hline Minder dan $€ 7.500$ & 2,7 & 5,2 & 10,4 & 4,2 & 9,3 \\
\hline Tussen $€ 7.500$ en $€ 15.000$ & 11,5 & 9,4 & 19,2 & 9,5 & 17,0 \\
\hline Tussen $€ 15.000$ en $€ 22.500$ & 24,0 & 19,8 & 24,4 & 21,3 & 25,9 \\
\hline Tussen $€ 22.500$ en $€ 30.000$ & 29,5 & 32,6 & 24,2 & 29,2 & 23,9 \\
\hline Meer dan $€ 30.000$ & 31,6 & 31,6 & 19,3 & 34,9 & 21,9 \\
\hline Totaal & 100 & 100 & 100 & 100 & 100 \\
\hline
\end{tabular}

Bron: CBS (OVG) 
Tabel 5.8 laat zien dat de blijvers van Gelderland gemiddeld een kortere reisafstand hebben dan de landelijke blijvers. Zo blijkt dat bijna $39 \%$ van de mensen die in Gelderland wonen en werken een reisafstand hebben van minder dan 5 kilometer, terwijl dezelfde groep mensen op landelijk niveau aanmerkelijk kleiner is, bijna $34 \%$. Tevens blijkt dat meer landelijke pendelaars een grote afstand afleggen vergeleken met de Gelderse pendelaars. Ruim 45\% van de landelijke pendelaars heeft een reisafstand van meer dan 50 kilometer, terwijl gemiddeld $40 \%$ van de Gelderse pendelaars een reisafstand hebben van 50 kilometer of meer. Ook hier kan de verklaring zijn dat het gemiddelde opleidingsniveau van de Gelderse pendelaars wat lager ligt dan dat van de landelijke pendelaars.

Tabel 5.8

De reisafstand van pendelaars en blijvers van Gelderland en Nederland, 2001

\begin{tabular}{|c|c|c|c|c|c|}
\hline \multirow[t]{2}{*}{ Reisafstand } & \multicolumn{3}{|c|}{ Gelderland } & \multicolumn{2}{|c|}{ Nederland } \\
\hline & $\begin{array}{c}\text { Inkomende } \\
\text { pendel } \\
\%\end{array}$ & $\begin{array}{c}\text { Uitgaande } \\
\text { pendel } \\
\%\end{array}$ & $\begin{array}{c}\text { Blijvers } \\
\%\end{array}$ & $\begin{array}{c}\text { Pendelaars } \\
\%\end{array}$ & $\begin{array}{c}\text { Blijvers } \\
\%\end{array}$ \\
\hline $0-5 \mathrm{~km}$ & 6,8 & 7,5 & 38,6 & 7,0 & 33,8 \\
\hline $5-10 \mathrm{~km}$ & 6,5 & 7,6 & 18,4 & 6,6 & 18,7 \\
\hline $10-15 \mathrm{~km}$ & 8,5 & 8,0 & 11,3 & 6,0 & 11,9 \\
\hline $15-20 \mathrm{~km}$ & 9,0 & 5,7 & 6,3 & 5,2 & 7,9 \\
\hline $20-30 \mathrm{~km}$ & 12,1 & 11,0 & 9,4 & 10,3 & 11,0 \\
\hline $30-40 \mathrm{~km}$ & 11,0 & 8,1 & 5,2 & 10,6 & 6,2 \\
\hline $40-50 \mathrm{~km}$ & 8,4 & 8,8 & 2,9 & 9,0 & 3,5 \\
\hline $50 \mathrm{~km}$ of meer & 37,7 & 43,4 & 7,8 & 45,4 & 7,2 \\
\hline Totaal & 100 & 100 & 100 & 100 & 100 \\
\hline
\end{tabular}

Bron: CBS (OVG)

Naast de reisafstand is het interessant om de reistijd van de verschillende groepen werkenden met elkaar te vergelijken. De reistijd geeft een indicatie van de bereikbaarheid van de werkgelegenheidscentra waar mensen werken. Zo blijkt uit tabel 5.9 dat de inkomende pendel van Gelderland doorgaans een kortere reistijd hebben dan de uitgaande pendel. Blijkbaar staan mensen die vanuit Gelderland elders gaan werken langer in de file, of hebben zij anderszins te maken met een ongunstigere infrastructuur, dan mensen die vanuit andere provincies in Gelderland komen werken. Dit verschil in reistijd is echter niet aanwezig indien men de uitgaande pendel van Gelderland met de Nederlandse pendelaars vergelijkt. 
Tabel 5.9

De reistijd in minuten van pendelaars en blijvers van Gelderland en Nederland, 2001

\begin{tabular}{lccccc}
\hline Reistijd in minuten & \multicolumn{3}{c}{ Gelderland } & & \multicolumn{2}{c}{ Nederland } \\
& $\begin{array}{c}\text { Inkomende } \\
\text { pendel } \\
\%\end{array}$ & $\begin{array}{c}\text { Uitgaande } \\
\text { pendel } \\
\%\end{array}$ & Blijvers & Pendelaars & Blijvers \\
& & $\%$ & $\%$ & $\%$ \\
Tussen 0 en 10 & 4,5 & 4,4 & 21,6 & 3,9 & 16,6 \\
Tussen 10 en 20 & 13,4 & 11,8 & 33,0 & 10,8 & 31,3 \\
Tussen 20 en 30 & 12,2 & 10,4 & 14,1 & 9,2 & 15,4 \\
Tussen 30 en 45 & 21,8 & 18,0 & 15,5 & 17,2 & 17,7 \\
Tussen 45 en 60 & 14,8 & 13,2 & 6,5 & 14,6 & 8,8 \\
Tussen 60 en 90 & 19,8 & 22,9 & 6,4 & 23,6 & 7,2 \\
Tussen 90 en 120 & 8,7 & 9,1 & 1,6 & 9,8 & 1,9 \\
Meer dan 120 & 4,7 & 10,2 & 1,3 & 10,9 & 1,2 \\
Totaal & 100 & 100 & 100 & 100 & 100 \\
\hline
\end{tabular}

Bron: CBS (OVG)

\subsection{Pendelstromen als oplossing voor regionale arbeidsmarktdiscrepanties}

In het kader van hoofdstuk 4 is het interessant om de arbeidsmarktperspectieven voor de nieuwkomers en de knelpunten in de personeelsvoorziening voor de werkgevers in verband te brengen met de pendelstromen. Voor de middellange termijn geldt namelijk dat voor de Pedagogische beroepen, Economisch-administratieve beroepen, Informaticaberoepen en Sociaal-culturele beroepen de knelpunten in de personeelsvoorziening het grootst zijn. Voor de Agrarische en Verzorgende en dienstverlenende beroepen hoeft men geen knelpunten te verwachten in de personeelsvoorziening. Pendelstromen geven de mogelijkheid deze knelpunten te reduceren. Derhalve zal deze paragraaf een overzicht geven van de pendelstromen met de drie belangrijkste provincies, Utrecht, Noord-Brabant en Overijssel.

Uit tabel 5.10 blijkt dat de mensen die in Gelderland wonen maar in Utrecht werken voornamelijk werkzaam zijn in de Economisch-administratieve beroepen, de Technische en industrieberoepen en de Verzorgende en dienstverlenende beroepen. Voor de Economisch-administratieve beroepen worden echter grote knelpunten verwacht in de personeelsvoorziening op de middellange termijn in Gelderland. Door deze uitgaande pendelstroom vanuit Gelderland naar Utrecht te reduceren zouden de toekomstige knelpunten in de personeelsvoorziening verlicht kunnen worden. Dit zou tevens bereikt kunnen worden door de inkomende pendelstroom vanuit Utrecht naar Gelderland in deze beroepsklasse te stimuleren.

In de Technische en industrieberoepen worden enige knelpunten verwacht in de personeelsvoorziening op de middellange termijn. Ook voor deze beroepsklasse geldt dat door een afname van de uitgaande pendel of een toename van de inkomende pendel de knelpunten in de personeelsvoorziening voor werkgevers verminderd kunnen worden. De Verzorgende en dienstverlenende beroepen hoeven daarentegen vrijwel geen knelpunten in de personeelsvoorziening te verwachten op de middellange termijn. 
Tabel 5.10

Pendelstromen tussen Gelderland en Utrecht uitgesplitst naar beroepsklasse, gemiddelde 2000-2001

$\begin{array}{cc}\text { Beroepsklasse } & \begin{array}{c}\text { Werkenden vanuit } \\ \text { Gelderland naar Utrecht Utrecht naar Gelderland } \\ \%\end{array} \\ \%\end{array}$

Pedagogische beroepen

Culturele beroepen

Agrarische beroepen

Technische en industrie beroepen

Transportberoepen

Medische en paramedische beroepen

Economisch-administratieve beroepen

Informaticaberoepen

Sociaal-culturele beroepen

Verzorgende en dienstverlenende

beroepen

Openbare orde- en veiligheidsberoepen

Totaal (incl. overig)

$\begin{array}{rr}5 & 7 \\ 1 & 3 \\ 1 & 1 \\ 17 & 24 \\ 5 & 9 \\ 5 & 5 \\ 38 & 28 \\ 9 & 9 \\ 4 & 4 \\ 8 & 6 \\ 3 & \\ & \\ & \\ 100 & 100\end{array}$

Bron: CBS (EBB)

Aangezien er op de middellange termijn knelpunten in de personeelsvoorziening verwacht kunnen worden in de Pedagogische, Informatica- en Sociaal-culturele beroepen zou er arbeidsmarktbeleid gevoerd kunnen worden om de pendelstromen in deze beroepsklassen in de voor Gelderland gewenste richting te stimuleren. In provincies met een overschot aan deze mensen zouden dan bijvoorbeeld regionale wervingscampagnes gestart kunnen worden.

Tabel 5.11

Pendelstromen tussen Gelderland en Noord-Brabant uitgesplitst naar beroepsklasse, gemiddelde 2000-2001

Beroepsklasse

Werkenden vanuit Gelderland naar NoordBrabant

Pedagogische beroepen

Culturele beroepen

Agrarische beroepen

Technische en industrie beroepen

Transportberoepen

Medische en paramedische beroepen

Economisch-administratieve beroepen

Informaticaberoepen

Sociaal-culturele beroepen

Verzorgende en dienstverlenende beroepen

Openbare orde- en veiligheidsberoepen

Totaal (incl. overig)

Bron: CBS (EBB)
Werkenden vanuit

Noord-Brabant naar Gelderland

2

20

8

35

3

12

100 
De inkomende pendel van Gelderland vanuit Noord-Brabant komt in grote lijnen overeen met de uitgaande pendel vanuit Gelderland naar Noord-Brabant. Toch blijkt uit tabel 5.11 dat $34 \%$ van de uitgaande pendel werkzaam is in Economischadministratieve beroepen. Zoals uit hoofdstuk 4 is gebleken worden werkgevers in deze beroepsklasse geconfronteerd met grote knelpunten in de personeelsvoorziening op de middellange termijn. Het is derhalve vanuit Gelders perspectief wenselijk om de uitgaande pendel in deze beroepsklasse terug te dringen.

Tabel 5.12 laat de pendelstromen tussen Gelderland en Overijssel zien. Hieruit blijkt dat $37 \%$ van de uitgaande pendel naar Overijssel werkzaam is in de Economischadministratieve beroepen. De inkomende pendel voor Gelderland in deze beroepsklasse bedraagt slechts $28 \%$. Aangezien werkgevers in deze beroepsklasse geconfronteerd zullen worden met grote knelpunten in de personeelsvoorziening is het wenselijk deze pendelstromen aan te passen aan de toekomstige tekorten. Dit betekent dat getracht zou kunnen worden de uitgaande pendel van $37 \%$ te verminderen en de inkomende pendel van $28 \%$ te laten toenemen.

Tabel 5.12

Pendelstromen tussen Gelderland en Overijssel uitgesplitst naar beroepsklasse, gemiddelde 2000-2001

\begin{tabular}{|c|c|c|}
\hline Beroepsklasse & $\begin{array}{c}\text { Werkenden vanuit } \\
\text { Gelderland naar } \\
\text { Overijssel } \\
\%\end{array}$ & $\begin{array}{c}\text { Werkenden vanuit } \\
\text { Overijssel naar } \\
\text { Gelderland } \\
\%\end{array}$ \\
\hline Pedagogische beroepen & 9 & 8 \\
\hline Culturele beroepen & 0 & 0 \\
\hline Agrarische beroepen & 1 & 1 \\
\hline Technische en industrie beroepen & 20 & 22 \\
\hline Transportberoepen & 6 & 3 \\
\hline Medische en paramedische beroepen & 6 & 5 \\
\hline Economisch-administratieve beroepen & 37 & 28 \\
\hline Informaticaberoepen & 3 & 7 \\
\hline Sociaal-culturele beroepen & 5 & 7 \\
\hline Verzorgende en dienstverlenende beroepen & 9 & 12 \\
\hline Openbare orde- en veiligheidsberoepen & 1 & 4 \\
\hline Totaal (incl. overig) & 100 & 100 \\
\hline
\end{tabular}

Bron: CBS (EBB)

Aangezien pendelstromen de regionale discrepanties tussen vraag en aanbod van arbeid kunnen verminderen is het interessant de knelpunten in de personeelsvoorziening voor werkgevers voor zowel Gelderland als Nederland in kaart te brengen.

Tabel 5.13 laat zien dat de toekomstige knelpunten in de personeelsvoorziening voor werkgevers op de middellange termijn in Gelderland doorgaans minder groot zijn vergeleken met de rest van Nederland. De Culturele beroepen hoeven vrijwel geen knelpunten te verwachten op de middellange termijn in Gelderland, terwijl werkgevers in de rest van Nederland geconfronteerd zullen worden met grote 
knelpunten. Door de uitgaande pendel van Gelderland te laten toenemen in deze beroepsklasse (oftewel de inkomende pendel te laten afnemen) kunnen de knelpunten in de rest van Nederland verlicht worden. Bij de Transportberoepen daarentegen worden in de rest van Nederland vrijwel geen knelpunten verwacht, terwijl in Gelderland sprake zal zijn van enige knelpunten in de personeelsvoorziening. Door de uitgaande pendel in deze beroepsklasse te laten afnemen oftewel de inkomende pendel te laten toenemen kunnen de knelpunten in de personeelsvoorziening voor Gelderse werkgevers verminderd worden.

Tabel 5.13

Gewenste pendel op basis van de indicator toekomstige knelpunten in de personeelsvoorziening naar beroepsklasse (ITKB) voor Gelderland en Nederland in 2006

\begin{tabular}{|c|c|c|c|}
\hline \multirow[t]{2}{*}{ Beroepsklasse } & \multicolumn{2}{|c|}{ Typering ITKB } & \multirow{2}{*}{$\begin{array}{l}\text { Gewenste pendel vanuit de } \\
\text { provincie Gelderland }\end{array}$} \\
\hline & Gelderland & Nederland & \\
\hline Pedagogische beroepen & Groot & Zeer groot & $\begin{array}{l}\text { Toename uitgaande pendel } \\
\text { Afname inkomende pendel }\end{array}$ \\
\hline Culturele beroepen & Vrijwel geen & Groot & $\begin{array}{l}\text { Toename uitgaande pendel } \\
\text { Afname inkomende pendel }\end{array}$ \\
\hline Agrarische beroepen & Vrijwel geen & Vrijwel geen & Geen \\
\hline $\begin{array}{l}\text { Technische en industrie } \\
\text { beroepen }\end{array}$ & Enige & Groot & $\begin{array}{l}\text { Toename uitgaande pendel } \\
\text { Afname inkomende pendel }\end{array}$ \\
\hline Transportberoepen & Enige & Vrijwel geen & $\begin{array}{l}\text { Afname uitgaande pendel } \\
\text { Toename inkomende pendel }\end{array}$ \\
\hline $\begin{array}{l}\text { Medische en } \\
\text { paramedische beroepen }\end{array}$ & Enige & Zeer groot & $\begin{array}{l}\text { Toename uitgaande pendel } \\
\text { Afname inkomende pendel }\end{array}$ \\
\hline $\begin{array}{l}\text { Economisch-administratieve } \\
\text { beroepen }\end{array}$ & Groot & Groot & Geen \\
\hline Informaticaberoepen & Groot & Groot & Geen \\
\hline Sociaal-culturele beroepen & Groot & Groot & Geen \\
\hline $\begin{array}{l}\text { Verzorgende en } \\
\text { dienstverlenende beroepen }\end{array}$ & Vrijwel geen & Vrijwel geen & Geen \\
\hline $\begin{array}{l}\text { Openbare orde- en } \\
\text { veiligheidsberoepen }\end{array}$ & Enige & Groot & $\begin{array}{l}\text { Toename uitgaande pendel } \\
\text { Afname inkomende pendel }\end{array}$ \\
\hline
\end{tabular}

Bron: ROA

Tabel 5.14 laat zien dat over het algemeen op de middellange termijn betere arbeidsmarktperspectieven verwacht worden in Gelderland vergeleken met de rest van Nederland. Dit betekent dat schoolverlaters en werkzoekenden niet noodzakelijkerwijs in andere provincies een baan hoeven te zoeken om aan het werk te komen. Alleen schoolverlaters en werkzoekenden met als opleidingsachtergrond VMBO Landbouw en natuurlijke omgeving zullen sneller een baan vinden indien zij pendelen naar andere provincies. Daar zijn de arbeidsmarktperspectieven namelijk beter dan in Gelderland. 
Tabel 5.14

Gewenste pendel op basis van de indicator toekomstige arbeidsmarktperspectieven (ITA) naar opleidingssector voor Gelderland en Nederland in 2006

\begin{tabular}{|c|c|c|c|}
\hline \multirow[t]{2}{*}{ Opleidingssector } & \multicolumn{2}{|c|}{ Typering ITA } & \multirow{2}{*}{$\begin{array}{l}\text { Gewenste pendel vanuit de } \\
\text { provincie Gelderland }\end{array}$} \\
\hline & Gelderland & Nederland & \\
\hline Basisonderwijs & Goed & Redelijk & $\begin{array}{l}\text { Afname uitgaande pendel } \\
\text { Toename inkomende pende }\end{array}$ \\
\hline VMBO Theorie & Goed & Matig & $\begin{array}{l}\text { Afname uitgaande pendel } \\
\text { Toename inkomende pende }\end{array}$ \\
\hline $\begin{array}{l}\text { VMBO Landbouw en } \\
\text { natuurlijke omgeving }\end{array}$ & Slecht & Matig & $\begin{array}{l}\text { Toename uitgaande pendel } \\
\text { Afname inkomende pendel }\end{array}$ \\
\hline VMBO Techniek & Goed & Matig & $\begin{array}{l}\text { Afname uitgaande pendel } \\
\text { Toename inkomende pende }\end{array}$ \\
\hline VMBO Economie & Slecht & Slecht & Geen \\
\hline VMBO Verzorging & Redelijk & Matig & $\begin{array}{l}\text { Afname uitgaande pendel } \\
\text { Toename inkomende pende }\end{array}$ \\
\hline HAVO/VWO & Redelijk & Matig & $\begin{array}{l}\text { Afname uitgaande pendel } \\
\text { Toename inkomende pende }\end{array}$ \\
\hline $\begin{array}{l}\text { MBO Landbouw en } \\
\text { natuurlijke omgeving }\end{array}$ & Goed & Goed & Geen \\
\hline MBO Techniek & Goed & Goed & Geen \\
\hline MBO Economie & Goed & Goed & Geen \\
\hline $\begin{array}{l}\text { MBO Dienstverlening } \\
\text { en gezondheidszorg }\end{array}$ & Goed & Goed & Geen \\
\hline
\end{tabular}

Bron: ROA

Behalve een vergelijking tussen de verwachte toekomstige arbeidsmarktmarktsituatie in Gelderland en Nederland kan gekeken worden naar de gewenste verandering in zowel de inkomende als de uitgaande pendel van Gelderland om toekomstige knelpunten in de personeelsvoorziening op te lossen. Door de toekomstige tekorten per beroepsklasse in verband te brengen met het huidige pendelsaldo wordt er een beeld geschetst van de gewenste pendelverandering. Tabel 5.15 laat zien dat het aantal inkomende pendelaars voor de Pedagogische beroepen in totaliteit met $64 \%$ moet toenemen om de toekomstige knelpunten in de personeelsvoorziening in deze beroepsklasse op te lossen. Hetzelfde wordt bereikt indien het aantal uitgaande pendelaars met 55\% afneemt. Hieruit kan geconcludeerd worden dat de knelpunten voor deze beroepsklasse slechts in zeer beperkte mate kunnen worden verlicht door deze veranderingen van de pendelstromen, temeer omdat voor de Pedagogische beroepen de knelpunten in de rest van Nederland nog groter zijn dan in Gelderland (zie tabel 5.13).

In dit hoofdstuk is al een aantal malen naar voren gekomen dat de uitgaande pendelaars voornamelijk werkzaam zijn in de Economisch-administratieve beroepen, ondanks de verwachting dat werkgevers grote knelpunten in de personeelsvoorziening in deze beroepsklasse kunnen verwachten op de middellange termijn in Gelderland. Het afremmen van de uitgaande pendel of het stimuleren van de inkomende pendel zou een oplossing kunnen zijn om de toekomstige knelpunten in de personeelsvoorziening voor deze beroepsklasse te verminderen. De toekomstige knelpunten in de personeelsvoorziening in deze beroepsklasse zouden geheel 
verdwijnen indien het aantal uitgaande pendelaars met $20 \%$ afneemt, hetgeen dus een aanzienlijke aanpassing van de pendelstromen is. Dit scenario is echter ook niet eenvoudig te realiseren omdat evenals in Gelderland de knelpunten in de personeelsvoorziening voor werkgevers elders in Nederland groot zijn voor de Economisch-administratieve beroepen (zie tabel 5.13).

Tabel 5.15

Gewenste verandering van pendelstromen (gemiddelde 2000-2001) in procenten van de verwachte tekorten of overschotten tot 2006 per beroepsklasse, Gelderland

Beroepsklasse

Inkomende pendel $\%$
Uitgaande pendel $\%$

Tot 2006

Pedagogische beroepen

Culturele beroepen

Agrarische beroepen

Technische en industrie beroepen

Transportberoepen

Medische en paramedische beroepen

Economisch-administratieve beroepen

Informaticaberoepen

Sociaal-culturele beroepen

Verzorgende en dienstverlenende

beroepen

Openbare orde- en veiligheidsberoepen

$\begin{array}{rr}64 & -55 \\ -15 & 21 \\ 4 & -4 \\ 6 & -5 \\ - & - \\ - & - \\ 29 & -21 \\ 26 & -18 \\ 35 & -31 \\ - & - \\ & -16\end{array}$

Bron: ROA/CBS (EBB)

Enige knelpunten worden verwacht op de middellange termijn bij de Technische en industrieberoepen. Een relatief kleine daling in het aantal uitgaande pendelaars is voldoende om deze knelpunten op te lossen. Dit zou tevens bereikt kunnen worden door het aantal inkomende pendelaars met $6 \%$ te laten toenemen. Ook hier geldt echter dat de knelpunten in de personeelsvoorziening voor werkgevers landelijk groter zijn dan voor Gelderland (tabel 5.13).

\subsection{De buitenlandse arbeidsmarkt}

De bestaande en toekomstige knelpunten op de Gelderse arbeidsmarkt kunnen verminderd worden door het stimuleren van het buitenlands arbeidsaanbod. Het buitenlands arbeidsaanbod kan op twee manieren gestimuleerd worden, namelijk aan de hand van grenspendel en arbeidsmigratie. Op het gebied van taal, cultuur, sociale zekerheid en belastingen bestaan echter nog altijd een aantal barrières tussen de landen waardoor daadwerkelijke migratie een minder optimale oplossing is. Grenspendel daarentegen kan, naast de pendel vanuit andere Nederlandse provincies, bijdragen aan het oplossen van knelpunten op de Gelderse arbeidsmarkt. Het stimuleren van grenspendel heeft tot gevolg dat steeds meer mensen vanuit België en Duitsland in Gelderland komen werken. Echter, deze instroom brengt een aantal problemen met zich mee. Als eerste zijn er nog steeds fiscale belemmeringen, de belastingstelsels van de drie landen zijn namelijk nog niet geheel op elkaar afgesteld. Naast fiscale belemmeringen is er sprake van sociaal-economische 
belemmeringen. De mobiliteit tussen de aangrenzende landen wordt beperkt door taalbarrières.

Er zijn dus vele belemmeringen die de grenspendel op een laag peil houden. Deze belemmeringen spelen een minder belangrijke rol bij de binnenlandse pendelstromen. Mede door de ruime beschikbaarheid van informatie en het ontbreken van taal- en cultuurverschillen kan verklaard worden waarom er eerder mobiliteit optreedt op grote afstand binnen een land dan op geringe afstand tussen landen. Bovendien wachten werkzoekenden liever in eigen land op een betere economische situatie dan dat ze werk zoeken in het buitenland, hetgeen ook wel een positieve 'option value of waiting' wordt genoemd. ${ }^{27}$

De pendelstromen tussen Nederland en met name Duitsland kunnen een reductie in de krapte van de regionale arbeidsmarkt in Gelderland bewerkstelligen. ${ }^{28}$ Uit gegevens van het CBS (Statistiek Grensarbeid, 2001) blijkt dat er aanmerkelijk meer mensen naar Nederland komen om te werken vanuit België dan omgekeerd en dat er meer mensen vanuit Nederland in Duitsland gaan werken dan omgekeerd. Er is dus sprake van een positief pendelsaldo met België en een negatief pendelsaldo met Duitsland. De Gelderse pendel met België is echter zo gering (minder dan 200 werkenden in 2001) dat deze hier verder niet besproken zal worden.

Tabel 5.16

Omvang van pendelstromen tussen Duitsland en de provincies van Nederland, 2001

\begin{tabular}{lccc}
\hline & $\begin{array}{c}\text { Inkomende pendel vanuit } \\
\text { Duitsland (naar Nederland) }\end{array}$ & $\begin{array}{c}\text { Uitgaande pendel vanuit } \\
\text { Nederland (naar Duitsland) }\end{array}$ & Pendelsaldo \\
Groningen & 55 & 195 & - \\
Friesland & 10 & 25 & - \\
Drenthe & 280 & 300 & + \\
Overijssel & 945 & 1.160 & - \\
Flevoland & 0 & 10 & - \\
Gelderland & 1.205 & 2.190 & + \\
Utrecht & 70 & 35 & + \\
Noord-Holland & 125 & 65 & + \\
Zuid-Holland & 180 & 50 & - \\
Zeeland & 20 & 15 & - \\
Noord-Brabant & 1.240 & 395 & + \\
Limburg & 2.100 & 8.105 & \\
& & & \\
Totaal (a) & 7.975 & 12.590 & \\
& & & \\
\hline
\end{tabular}

(a) inclusief provincie onbekend

Bron: CBS (Statistiek Grensarbeid)

Tabel 5.16 geeft een overzicht van de grenspendel met Duitsland. Opvallend is dat $15 \%$ van de grenspendel met Duitsland naar de provincie Gelderland komt om te werken en dat $17 \%$ van de Nederlandse pendelaars die naar Duitsland gaan

27. Zie T. Straubhaar en A. Wolter (1997), Globalisation, internal labour markets and the migration of the highly skilled, Intereconomics, Vol. 32, pp. 174-180.

28. J. van Cruchten en R. Kuijpers, (2002), Grensarbeid tussen Nederland en België of Duitsland, Sociaal-economische maandstatistiek, CBS, 2002/4. 
afkomstig zijn uit Gelderland. Het pendelsaldo is derhalve negatief en bedraagt voor Gelderland 985 personen in 2001. De omvang van de grenspendel met Duitsland wordt weergegeven door figuur 5.1.

Begin jaren negentig werd de Nederlandse arbeidsmarkt gekenmerkt door een relatief hoge werkloosheid. Figuur 5.1 laat zien dat de pendelstroom vanuit Nederland naar Duitsland aanzienlijk is toegenomen in deze periode. De inkomende pendel is in die periode constant gebleven. Vanaf 1998 is ook de inkomende pendel voor Nederland vanuit Duitsland aanzienlijk toegenomen. Tevens laat figuur 5.1 zien dat vanaf 1995 het pendelsaldo aanmerkelijk minder negatief is geworden. De stijgende inkomende pendel en de dalende uitgaande pendel zou kunnen betekenen dat Nederland een steeds aantrekkelijkere arbeidsmarkt is geworden voor de werkenden in Duitsland. De arbeidsmarkt lijkt dus te reageren op verschillen in internationale schaarsteverhoudingen.

Figuur 5.1

De omvang van de grenspendel tussen Nederland en Duitsland in de periode 1990-2001

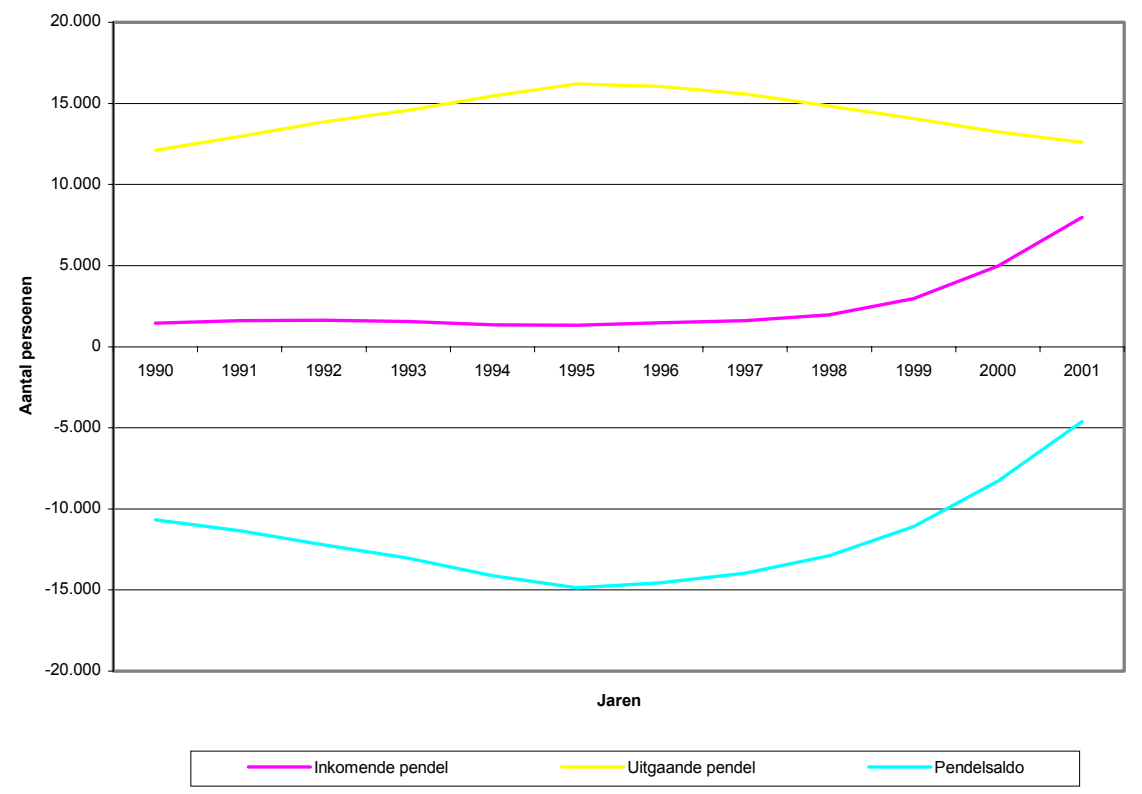

Bron: CBS (Statistiek Grensarbeid) 



\section{Het onbenutte arbeidspotentieel in Gelderland}

Het onbenutte arbeidspotentieel van Gelderland omvat 331.000 personen die niet werken. ${ }^{29}$ Binnen het onbenutte arbeidspotentieel zijn alleen de 27.000 werklozen actief op zoek naar werk. Voor het verlichten van de knelpunten op de arbeidsmarkt zijn daarnaast de 28.000 niet-participerenden van belang die weliswaar niet actief zoeken naar werk maar wel beschikbaar zijn voor de arbeidsmarkt. De overige nietparticiperenden zijn niet beschikbaar voor de arbeidsmarkt, en vormen veruit de grootste groep binnen het onbenutte arbeidspotentieel.

Slechts $46 \%$ van het onbenutte arbeidspotentieel heeft een middelbare opleiding of hoger (een zgn. 'startkwalificatie'), tegenover $70 \%$ van de werkenden. Het gemiddelde opleidingsniveau van de werklozen is weliswaar lager dan van de werkenden maar hoger dan van de niet-participerenden. In tegenstelling tot de werkenden zijn de werklozen en de niet-participerenden in meerderheid vrouwen. Het grootste gedeelte van de niet-participerenden heeft geen intentie om te gaan werken en zal daarom zeer moeilijk kunnen worden gemotiveerd werk te aanvaarden. De meeste mannelijke niet-participerenden die niet meer willen werken hebben als reden hiervoor dat zij arbeidsongeschikt zijn, vervroegd zijn uitgetreden of met pensioen zijn. Voor de vrouwen zijn met name de huishoudelijke werkzaamheden binnenshuis, de gezinssituatie en arbeidsongeschiktheid de belangrijkste redenen om niet te participeren op de arbeidsmarkt.

Het onbenutte arbeidspotentieel is tussen 1993-94 en 2000-01 met ongeveer 70.000 personen in aantal gedaald. De opgaande conjunctuur heeft hierbij een belangrijk rol gespeeld. Het aantal werklozen is in deze periode bijna gehalveerd. Ook de voortdurende stijging van het opleidingsniveau heeft een positief effect op de gemiddelde bereidheid om te participeren op de arbeidsmarkt. Zo is binnen het onbenutte arbeidspotentieel het aantal personen dat aangeeft niet te willen werken absoluut gezien het meest gedaald. Juist daar waar de knelpunten in de personeelsvoorziening voor werkgevers het grootste zijn, namelijk op MBO-, HBOen WO-niveau, is het aantal werklozen en beschikbare niet-participerenden relatief het kleinst. Naast de opleidingsachtergrond speelt de relevante werkervaring vaak een nog belangrijkere rol voor werklozen en herintreders om te kunnen concurreren met schoolverlaters op de arbeidsmarkt.

\subsection{Inleiding}

Het stimuleren van het onbenutte arbeidspotentieel om te gaan werken is vanwege de toenemende vergrijzing van de beroepsbevolking zeer belangrijk. ${ }^{30}$ Daarnaast kunnen knelpunten op de arbeidsmarkt in tijden van hoogconjunctuur worden verlicht door een toename van de arbeidsparticipatie. Om de arbeidsparticipatie en de

29. De gegevens hebben betrekking op het gemiddelde van 2000-2001.

30. WRR (2000), Doorgroei van Arbeidsparticipatie, Wetenschappelijke Raad voor het Regeringsbeleid, Rapporten aan de Regering, Nr. 57, Den Haag. 
inzetbaarheid te kunnen stimuleren is het verkrijgen van inzicht in de achtergrondkenmerken en de inzetbaarheid van het onbenutte arbeidspotentieel van belang.

De werklozen vormen een belangrijk deel van het onbenutte arbeidspotentieel, omdat zij daadwerkelijk op zoek zijn naar betaald werk. Het grootste deel van het onbenutte arbeidspotentieel bestaat echter uit een zeer heterogene groep van personen uit de potentiële beroepsbevolking, de zogeheten niet-participerenden of stille reserve. Deze mensen bieden zich niet aan op de arbeidsmarkt, omdat ze huishoudelijke of zorgtaken hebben, studeren, arbeidsongeschikt zijn, vrijwilligerswerk verrichten, vervroegd met pensioen zijn gegaan, etc. In dit rapport zal eerst een overzicht gegeven worden van de samenstelling van het onbenutte arbeidspotentieel in Gelderland en de veranderingen van deze samenstelling over de tijd. Vervolgens zal worden geanalyseerd hoe het onbenutte arbeidspotentieel tekorten aan personeel in Gelderland kan oplossen. Ten slotte wordt bekeken waarom de nietparticiperenden verkiezen niet te werken.

Achtereenvolgens zullen de volgende vragen aan de orde komen:

- Hoe groot is het onbenutte arbeidspotentieel ten opzichte van de werkende beroepsbevolking in Gelderland en wat is de samenstelling van deze groep wat betreft geslacht, leeftijd, opleidingsachtergrond en reden van non-participatie? (paragraaf 6.2)

- Hoe heeft het onbenutte arbeidspotentieel zich in Gelderland over de tijd ontwikkeld qua omvang en samenstelling? (paragraaf 6.3)

- In hoeverre hebben de personen in het onbenutte arbeidspotentieel de juiste opleidingsachtergrond en werkervaring om in te springen bij tekorten in het arbeidsaanbod? (paragraaf 6.4)

\subsection{Achtergronden en kenmerken}

De volgende drie groepen kunnen binnen het onbenutte arbeidspotentieel onderscheiden worden ${ }^{31}$ :

- Personen die op zoek zijn naar werk en beschikbaar zijn voor de arbeidsmarkt, de werklozen ${ }^{32}$;

- Personen die weliswaar geen werk zoeken maar wel beschikbaar zijn voor de arbeidsmarkt, de beschikbare niet-participerenden;

- Personen die niet beschikbaar zijn voor de arbeidsmarkt, de niet beschikbare niet-participerenden.

31. In de analyse is de totale populatie van Gelderland aan de potentiële beroepsbevolking Deze is in dit rapport (en de Statistische Bijlage) gedefinieerd als iedereen tussen 15 en 64 jaar, uitgezonderd scholieren en studenten.

32. Er wordt hier uitgegaan van werklozen volgens het begrip 'werkloze beroepsbevolking' van het CBS. Werklozen hebben geen baan van 12 uur of meer. Ze zijn de laatste vier weken op enigerlei wijze op zoek geweest naar een dergelijke baan, en zijn in principe binnen twee weken beschikbaar voor een baan van 12 uur of meer. Zie de publicatie Enquête Beroepsbevolking 1999, CBS (Voorburg/Heerlen, 2000). 
De niet-werkenden worden ingedeeld in deze drie groepen op basis van hun bereidheid om te werken. Indien men bijvoorbeeld werkloos is en naar een baan zoekt, wordt er een grotere bereidheid getoond om werk te aanvaarden dan wanneer men geen werk zoekt. Daarnaast geeft de beschikbaarheid voor de arbeidsmarkt aan in welke mate iemand bereid is te werken. ${ }^{33}$ Uit tabel 6.1 wordt beeld verkregen van de omvang van deze drie groepen van niet-werkenden. Het blijkt dat het nietbeschikbare deel van de niet-participerenden veruit het grootst is binnen het onbenutte arbeidspotentieel. Het aantal werklozen is ongeveer even groot als het aantal beschikbare niet-participerenden.

Tabel 6.1 geeft verder een beeld van een aantal achtergrondkenmerken van de werklozen en de niet-participerenden in Gelderland in vergelijking met de werkenden. Onder de werklozen zijn de vrouwen oververtegenwoordigd: $61 \%$ van de werklozen is vrouw tegenover slechts $39 \%$ van de werkenden. Van de beschikbare nietparticiperenden en degenen die niet beschikbaar zijn voor de arbeidsmarkt, is zelfs meer dan driekwart van het vrouwelijk geslacht.

Niet-werkenden zijn relatief vaak lager opgeleid. In de tabel is dit duidelijk te zien: hoe lager men is opgeleid, des te minder men zich beschikbaar stelt voor de arbeidsmarkt. Immers, hoe hoger de individuele investering in onderwijs vanwege het volgen van een opleiding in plaats van het verrichten van betaald werk, des te groter de stimulans om deze investering te gelde te maken. Van belang is hierbij met name het verschil tussen enerzijds lager opgeleiden met ten hoogste een VMBO-diploma, en anderzijds middelbaar of hoger opgeleiden. Men spreekt in dit verband van een 'startkwalificatie' bij scholingsniveaus boven VMBO vanwege de betere kansen op de arbeidsmarkt met een dergelijke opleidingsniveau voor zowel starters als werkenden. Voor deze laatste groep kunnen met name de carrièremogelijkheden op de arbeidsmarkt erg beperkt zijn. Bijna de helft van alle niet-werkenden heeft ten hoogste een VMBO-opleiding, waarbij het percentage niet-beschikbaren zonder startkwalificatie bijna twee keer is zo groot als het percentage werkenden zonder startkwalificatie. Ten slotte is $58 \%$ van degenen die niet beschikbaar voor de arbeidsmarkt zijn, ouder dan 50 jaar. Dit illustreert dat non-participatie zich in belangrijke mate concentreert bij de vijftig-plussers en de (gehuwde) vrouwen. Voor de personen in de relatief grote groep van niet-beschikbaren in de leeftijdsklasse van 50 tot en met 64 jaar mag dan ook worden aangenomen dat ze, in combinatie met andere factoren als langdurige inactiviteit en geringe inspanningen voor het verwerven van een baan, slechts een kleine kans hebben op een betaalde baan.

33. Het CBS hanteert hierbij in principe een grens van twee weken waarbinnen men bereid is om betaald werk te aanvaarden voor 12 uur of meer. Het CBS hanteert een ruimere grens van drie maanden als dit nodig is vanwege een opzegtermijn van de huidige werkkring (met een baan van minder dan 12 uur), het afronden van vrijwilligerswerk, het moeten regelen van kinderopvang of wegens ziekte of vakantie. 
Tabel 6.1

Werkenden, werklozen en niet-participerenden naar achtergrondkenmerken, Gelderland, gemiddelde 2000-2001

\begin{tabular}{|c|c|c|c|c|}
\hline \multirow[t]{2}{*}{ Kenmerk } & \multirow{2}{*}{$\begin{array}{c}\text { Werkend } \\
\%\end{array}$} & \multirow{2}{*}{$\begin{array}{c}\text { Werkloos } \\
\%\end{array}$} & \multicolumn{2}{|l|}{ Niet-participerend } \\
\hline & & & $\begin{array}{c}\text { Beschikbaar } \\
\%\end{array}$ & $\begin{array}{c}\text { Niet beschikbaar } \\
\%\end{array}$ \\
\hline \multicolumn{5}{|l|}{ Geslacht } \\
\hline Man & 61,0 & 39,3 & 21,2 & 23,9 \\
\hline Vrouw & 39,0 & 60,7 & 78,8 & 76,1 \\
\hline \multicolumn{5}{|l|}{ Leeftijd } \\
\hline 15-29 jaar & 23,0 & 26,3 & 15,8 & 5,9 \\
\hline 30-49 jaar & 56,7 & 57,1 & 47,6 & 36,3 \\
\hline 50-64 jaar & 20,3 & 16,6 & 36,6 & 57,9 \\
\hline \multicolumn{5}{|l|}{ Opleiding } \\
\hline BO-VMBO & 30,1 & 42,4 & 44,7 & 56,0 \\
\hline MBO-HAVO-VWO & 43,3 & 34,5 & 38,2 & 32,4 \\
\hline HBO-WO & 26,3 & 22,6 & 17,1 & 11,6 \\
\hline Totaal & 100 & 100 & 100 & 100 \\
\hline Aantal & 818.000 & 27.000 & 28.000 & 276.000 \\
\hline
\end{tabular}

Bron: CBS(EBB)

Zoals hierboven al opgemerkt, zijn de niet-participerenden in tegenstelling tot de werklozen niet actief op zoek naar werk. Om meer inzicht te geven in de voorkeuren van de niet-participerenden ten aanzien van het zoeken naar een betaalde baan in de toekomst en hun redenen om zich niet beschikbaar te stellen voor de arbeidsmarkt, wordt hieronder gebruik gemaakt van de landelijke gegevens uit het OSA-Aanbodpanel. ${ }^{34}$ Tabel 6.2 laat zien dat maar liefst driekwart van de nietparticiperenden verwacht nooit meer betaald werk te gaan zoeken. Ruim $13 \%$ verwacht wel weer ooit naar betaald werk te zoeken. Onder vrouwen is het percentage dat verwacht in de toekomst (misschien) betaald werk te zoeken aanzienlijk groter dan onder mannen. Dit kan erop duiden dat het niet zoeken naar werk van de niet-participerende vrouwen meer dan bij niet-participerende mannen samenhangt met hun tijdelijke zorgtaken voor de kinderen. Maar liefst $90 \%$ van de niet-participerende mannen verwacht niet dat hij ooit nog betaald werk zal zoeken, tegenover slechts ongeveer tweederde van de niet-participerende vrouwen.

34. De gegevens van dit panel kunnen niet worden gedifferentieerd naar provincie. Verwacht mag worden dat er binnen Nederland geen grote regionale verschillen bestaan ten aanzien van de voorkeuren voor het verrichten van betaald werk en de redenen voor nonparticipatie. 
Tabel 6.2

Verwachtingen van niet-participerenden ten aanzien van het zoeken naar betaald werk, 2000

Verwachting

man vrouw Totaal

$\% \quad \%$

Ooit (weer) betaald werk zoeken

$\begin{array}{rrr}3,9 & 17,2 & 13,4 \\ 6,4 & 14,9 & 12,5 \\ 89,7 & 67,9 & 74,1 \\ 100 & 100 & 100\end{array}$

Totaal

Bron: OSA-Arbeidsaanbodpanel (2000)

Het bovenstaande roept de vraag op waarom een groot deel van de niet-participerenden niet werkt en ook verwacht nooit meer te gaan zoeken naar een betaalde baan. Uit tabel 6.3 blijkt dat er wat betreft de redenen voor non-participatie grote verschillen tussen mannen en vrouwen bestaan. Veruit de belangrijkste redenen voor mannen om geen betaald werk te verrichten zijn het bereiken van de pensioen- of VUT-gerechtigde leeftijd en arbeidsongeschiktheid. Beide redenen zijn voor ongeveer $90 \%$ van de mannen de verklaring waarom zij niet participeren op de arbeidsmarkt. Deze redenen spelen ook onder vrouwen, hoewel significant minder dan onder mannen. Ongeveer de helft van de vrouwen geeft aan dat de gezinssituatie of de taken binnenshuis de belangrijkste reden voor non-participatie zijn.

Tabel 6.3

Belangrijkste reden van non-participatie, 2000

$\begin{array}{lrrr}\text { Reden } & \begin{array}{r}\text { man } \\ \%\end{array} & \begin{array}{r}\text { vrouw } \\ \%\end{array} & \begin{array}{r}\text { totaal } \\ \%\end{array} \\ & & & \\ \text { Pensioen/VUT } & 44,7 & 6,5 & 17,4 \\ \text { Arbeidsongeschiktheid } & 45,5 & 23,7 & 29,9 \\ \text { Onvoldoende kinderopvangmogelijkheden } & 0 & 0,9 & 0,6 \\ \text { Gezinssituatie } & 0 & 12,0 & 8,6 \\ \text { Ontmoedigd over kansen op een baan } & 2,1 & 1,9 & 2,0 \\ \text { Andere zinvolle werkzaamheden thuis } & 2,1 & 35,3 & 25,9 \\ \text { Andere zinvolle werkzaamheden buitenshuis } & 0 & 9,4 & 6,9 \\ \text { Sociale uitkering is voldoende } & 0,9 & 1,4 & 1,2 \\ \text { Overig } & 4,3 & 8,9 & 7,6 \\ \text { Totaal } & 100,0 & 100,0 & 100,0 \\ & & & \end{array}$

Bron: OSA-Arbeidsaanbodpanel (2000)

Onder vrouwen is dit percentage veel groter dan onder mannen omdat zij nog altijd het grootste deel van de huishoudelijke en zorgtaken binnen het gezin op zich nemen. Opvallend is dat een gebrek aan kinderopvangmogelijkheden niet tot de belangrijkste redenen behoort om geen werk meer te willen. Hieruit kan worden afgeleid dat veel niet-participerenden zelf voor hun kinderen willen zorgen en dat een eventuele verbetering van kinderopvangmogelijkheden voor slechts een klein gedeelte onder hen de belangrijkste reden voor non-participatie is. 


\subsection{Veranderingen in het onbenutte arbeidspotentieel}

De omvang en samenstelling van het onbenutte arbeidspotentieel is aan veranderingen onderhevig. Dit kan in gang zijn gezet door zowel conjuncturele als structurele factoren. Wat betreft de conjuncturele factoren, kan gesteld worden dat over het algemeen de werkloosheid daalt bij een opgaande conjunctuur omdat werklozen sneller een baan vinden. Dit geldt in eerste instantie vooral voor werklozen die een goede opleiding met enige werkervaring combineren en niet al te lang werkloos zijn geweest. ${ }^{35} \mathrm{Na}$ een lange periode van grote krapte op de arbeidsmarkt, waarvan een jaar geleden nog sprake was, vormen zelfs de kansarme groepen op de arbeidsmarkt, zoals langdurig werklozen en ongeschoolden, een interessant arbeidspotentieel voor werkgevers om de knelpunten in de personeelsvoorziening te verlichten. Daarnaast is het denkbaar dat niet-participerenden eerder de arbeidsmarkt zullen betreden wanneer de arbeidsmarkt krapper is. Door de krappere arbeidsmarkt stijgen immers de kansen op een baan en verbeteren de arbeidsvoorwaarden, waardoor de baten van het zoeken naar werk en het aanvaarden van een betaalde baan, eerder opwegen tegen de kosten die gepaard gaan met bijvoorbeeld het solliciteren en het reizen naar het werk. Het is derhalve aannemelijk dat het onbenutte arbeidspotentieel gedurende de laatste jaren mede in omvang is verminderd door de arbeidsmarkt die steeds krapper werd. Dit betekent tevens dat de recente omslag in de conjunctuur bijdraagt aan de toename van het onbenutte arbeidspotentieel.

Tabel 6.2 laat de ontwikkeling van het aantal werklozen en niet-participerenden van Gelderland in de tijd zien. De niet-participerenden zijn opgesplitst in twee groepen: de beschikbare en de niet-beschikbare personen. In de tabel wordt de beschikbare groep verder opgesplitst in degenen die gedurende de laatste zes maanden wel en niet gezocht hebben naar betaald werk voor 12 uur per week of meer. ${ }^{36}$ De nietbeschikbare personen kunnen worden ingedeeld in vier groepen: personen die niet op korte termijn beschikbaar zijn, personen die geen werk willen, degenen die vervroegd zijn uitgetreden of met pensioen zijn en arbeidsongeschikten die niet beschikbaar maar in principe wel bereid zijn om te werken. De groep die geen behoefte heeft aan betaald werk blijkt verreweg het grootst te zijn.

35. Zie bijv. W. Smits (2001), Wie willen werkgevers? Personeelsselectie in de Zorg, de Metaalindustrie en de IT, ROA-W-2001/2, Maastricht.

36. Indien men echter in de afgelopen 4 weken werk heeft gezocht, behoort men niet tot deze groep maar tot de werklozen. 
Tabel 6.5

Ontwikkeling van het Gelderse onbenutte arbeidspotentieel

\begin{tabular}{lrrrr}
\hline Categorie & \multicolumn{2}{c}{$1993 / 1994$} & \multicolumn{2}{c}{$2000 / 2001$} \\
& Aantal & $\%$ & Aantal & $\%$ \\
& & & & \\
\hline Werkloos & 52.000 & 13,0 & 27.000 & 8,2 \\
& & & & \\
Beschikbaar & 13.000 & 3,3 & 8.000 & 2,4 \\
Werk gezocht laatste 6 mnd. & 23.000 & 5,8 & 20.000 & 6,1 \\
Geen werk gezocht laatste 6 mnd. & & & & \\
& 19.500 & 4,9 & 10.500 & 3,2 \\
Niet beschikbaar & 254.500 & 63,8 & 191.000 & 57,8 \\
Niet op korte termijn beschikbaar & 29.500 & 7,4 & 36.000 & 10,9 \\
Wil geen betaald werk & 7.500 & 1,9 & 38.000 & 11,5 \\
VUT of pensioen & & & & \\
Arbeidsongeschikt, bereid te werken & 399.000 & 100 & 330.500 & 100 \\
& & & & \\
Totaal onbenut arbeidspotentieel & & & &
\end{tabular}

Bron: CBS(EBB)

Uit tabel 6.5 blijkt dat, zoals verwacht mocht worden op basis van de opgaande conjunctuur in de voorbije jaren, het onbenutte arbeidspotentieel de afgelopen jaren sterk in omvang is afgenomen van 399.000 in 1993-94 naar 330.500 personen in 2000-01. Daarbij is het aantal werklozen bijna gehalveerd en het aantal mensen dat beschikbaar is voor de arbeidsmarkt aanzienlijk afgenomen. De afname van het aantal personen in deze twee groepen hangt zonder twijfel samen met de sterke verbetering van de algehele arbeidsmarktsituatie in de betreffende periode. Vooral degenen die op zoek zijn geweest naar een betaalde baan hebben hiervan geprofiteerd. Van degenen die niet beschikbaar zijn voor de arbeidsmarkt is de groep die niet wil werken het meest in aantal afgenomen. Ook hierbij kan de invloed van de conjunctuur op de arbeidsparticipatie zich hebben laten gelden. Daarnaast kan de daling van het aantal personen dat geen betaald werk wil verrichten samenhangen met zogenaamde 'cohort-effecten': de jonge leeftijdscohorten, waarvan met name de jongere vrouwen een grotere bereidheid hebben om te werken dan de oudere vrouwen, langzaam maar zeker de plaats innemen van de oudere leeftijdscohorten in de potentiële beroepsbevolking. Soortgelijke effecten kunnen ook spelen met betrekking tot het aantal personen dat niet op korte termijn beschikbaar is, dat bijna is gehalveerd. De toename van het aantal mensen dat met pensioen is of in een VUT-regeling zit, weerspiegelt de vergrijzing van de potentiële beroepsbevolking. Voorts is het aantal arbeidsongeschikten dat bereid is om te werken vervijfvoudigd.

Naast de conjunctuur spelen ook een meerdere structurele factoren een rol. Een mogelijke belangrijke reden voor de afname van het onbenutte arbeidspotentieel is 
de gestage toename van het gemiddelde opleidingsniveau van de bevolking. ${ }^{37}$ Zoals ook uit de vorige paragraaf al bleek gaat een hogere opleiding gepaard met een grotere arbeidsparticipatie. Over de langere termijn bezien zal het onbenutte arbeidspotentieel in omvang dalen bij een voortgaande stijging van het gemiddelde opleidingsniveau.

Tabel 6.3 laat zien dat het aandeel van het onbenutte arbeidspotentieel dat een opleiding op minimaal middelbaar niveau heeft genoten tussen 1993-1994 en 200001 is toegenomen met 4,3 procentpunten. Het percentage van het onbenutte arbeidspotentieel met minimaal een middelbare opleiding is echter beduidend lager dan het percentage middelbaar en hoger opgeleiden van de potentiële beroepsbevolking. Bovendien is dit percentage voor het onbenutte arbeidspotentieel met 0,7 procentpunten minder toegenomen dan voor de totale potentiële beroepsbevolking. Hieruit kan worden geconcludeerd dat wat betreft het opleidingsniveau de achterstand van het onbenutte arbeidspotentieel ten opzichte van de werkenden tussen 1993/94 en 2000/01 is vergroot. Dit betekent dat de nonparticipatie zich in toenemende mate concentreert bij degenen die niet beschikken over een startkwalificatie voor de arbeidsmarkt.

Tabel 6.6

Percentage van het onbenutte arbeidspotentieel met minimaal een middelbare opleiding, Gelderland

\begin{tabular}{lrr}
\hline Categorie & $1993-1994$ & $2000-2001$ \\
& $\%$ & $\%$ \\
\hline Werkloos & 54,5 & 57,5 \\
Beschikbaar & 47,5 & 55,3 \\
Niet Beschikbaar & 39,0 & 44,0 \\
Totaal onbenut arbeidspotentieel & & 46,1 \\
Totaal potentiële beroepsbevolking & 41,8 & 63,0 \\
& 58,0 & \\
\hline
\end{tabular}

Bron: $C B S(E B B)$

Een andere factor die eveneens een grote rol kan spelen voor de omvang van het onbenutte arbeidspotentieel zijn de toegenomen mogelijkheden voor met name vrouwen om een betaalde baan en de zorg voor de kinderen te combineren. Dit hangt samen met de laatste jaren sterk verbeterde voorzieningen voor kinderopvang en buitenschoolse opvang. Daarnaast kan voor de toename van de arbeidsparticipatie de sociaal-culturele invloed op de attitude tegenover het verrichten van betaald werk buitenshuis van belang zijn, evenals de toename van het aantal alleenstaanden en eenoudergezinnen, waardoor meer personen zijn aangewezen op het zelfstandig verwerven van hun inkomen.

37. Zie voor het belang van het opleidingsniveau voor de arbeidsparticipatie ook Cörvers and Golsteyn (2003), Changes in Women's Willingness to Work in a Tightening Labour Market: The Impact of Preferences, Wages and Individual Characteristics, Maastricht, te verschijnen. 


\subsection{Inzetbaarheid van het onbenutte arbeidspotentieel}

Voor het onbenutte arbeidspotentieel kan worden nagegaan of hun kwalificaties aansluiten op de arbeidsmarkt. In tabel 6.7 wordt per opleidingsniveau het percentage werkenden, werklozen, beschikbare niet-participerenden en nietbeschikbare niet-participerenden weergegeven. De werklozen en de nietparticiperenden zijn samengevoegd vanwege hun relatief kleine aantal per opleidingsniveau. Beide groepen zijn echter op korte termijn beschikbaar voor de arbeidsmarkt. Daarnaast wordt voor elk opleidingsniveau een indicatie gegeven van de toekomstige knelpunten in de personeelsvoorziening op de middellange termijn. De tabel geeft duidelijk aan dat het percentage werkenden stijgt naarmate het opleidingsniveau hoger is.

Uit de tabel blijkt verder dat voor de grote groep lager opgeleiden de vraagaanbodverhoudingen op de arbeidsmarkt geen stimulans zijn om weer aan het werk te gaan. Naast de over het algemeen kleinere bereidheid van niet-werkenden met een lagere opleiding om op de arbeidsmarkt te participeren, hebben de knelpunten op de arbeidsmarkt ook geen sterke aanzuigende werking op deze mensen om weer te gaan werken. Bij de middelbare en hogere opleidingen (MBO en hoger) zullen de knelpunten in de personeelsvoorziening daarentegen naar verwachting groot zijn. Met name voor deze groep is het dus van groot belang om adequaat in te spelen op de belemmeringen die men ondervindt om weer aan het werk te gaan.

Tabel 6.7

Arbeidsmarktpositie van de potentiële beroepsbevolking naar opleidingsniveau, gemiddelde 2001-2001, en de verwachte knelpunten in de personeelsvoorziening voor werkgevers in 2006 , Gelderland

\begin{tabular}{|c|c|c|c|c|c|}
\hline $\begin{array}{l}\text { Opleidings- } \\
\text { categorie }\end{array}$ & Werkend & $\begin{array}{l}\text { Werkloos of } \\
\text { beschikbaar }\end{array}$ & $\begin{array}{r}\text { Niet- } \\
\text { beschikbaar }\end{array}$ & Totaal & $\begin{array}{r}\text { Knelpunten } \\
\text { personeels- } \\
\text { voorziening } \\
\text { in } 2006 \\
(\text { ITKP) }\end{array}$ \\
\hline $\begin{array}{l}\text { Basisonderwijs } \\
\text { VMBO (excl. }\end{array}$ & 48,8 & 5,8 & 45,4 & 144.500 & enige \\
\hline VMBO theorie) & 62,4 & 5,1 & 32,5 & 202.000 & enige \\
\hline VMBO theorie & 63,6 & 6,8 & 29,6 & 78.500 & enige \\
\hline HAVO/VWO & 71,4 & 6,3 & 22,3 & 48.500 & enige \\
\hline MBO & 77,0 & 4,1 & 18,9 & 415.500 & groot \\
\hline $\mathrm{HBO}$ & 81,9 & 4,1 & 14,0 & 182.500 & groot* $^{*}$ \\
\hline WO & 87,4 & 4,5 & 8,1 & 77.000 & groot $^{*}$ \\
\hline Totaal & 71,2 & 4,8 & 24,0 & 1.149 .000 & \\
\hline
\end{tabular}

Noot:* Op basis van de verwachte landelijke vraag- en aanbodontwikkelingen.

Bron: CBS(EBB)/ROA 
In een recent onderzoek ${ }^{38}$ naar het selectiegedrag van werkgevers in de zorg-, IT-, en metaalsector wordt aangetoond dat werkgevers relevante werkervaring een belangrijk selectiecriterium vinden naast de genoten opleiding. Het beschikken over relevante werkervaring wordt door werkgevers in de IT- en metaalsector zelfs gezien als een belangrijker criterium dan de juiste opleidingsachtergrond. De reden hiervoor is dat in de IT-sector vaardigheden vereist zijn die door de voortdurende vernieuwingen snel verouderen en daardoor on the job moeten worden geleerd. In de zorgsector zijn daarentegen de formele opleidingseisen weer zeer belangrijk. In alle onderzochte sectoren blijkt dat herintreders met relevante werkervaring en de juiste opleidingsachtergrond een grotere kans hebben om te worden geselecteerd dan schoolverlaters. Ten slotte blijkt uit het onderzoek dat werkgevers hun selectiecriteria ten tijde van hoogconjunctuur op verschillende manieren in de drie onderzochte sectoren aanpassen. Zo geldt dat in de IT- en metaalsector, in tegenstelling tot de zorgsector, tekorten veel minder snel leiden tot openstaande vacatures. In plaats daarvan wordt eerder personeel aangetrokken dat niet over alle vereiste kwalificaties beschikt.

Uit het bovenstaande volgt dat het arbeidsverleden van het onbenutte arbeidspotentieel een indicatie geeft van de mogelijkheden om opnieuw betaald werk te gaan verrichten. Uit tabel 6.8 blijkt dat $95 \%$ van de niet-participerenden ooit werkervaring heeft opgedaan. Voor mannen ligt dit percentage nog hoger dan voor vrouwen. Toch zegt de onderstaande tabel nog weinig over de concurrentiepositie van werklozen en herintreders op de arbeidsmarkt: alleen als er sprake is van relevante werkervaring kunnen werklozen en herintreders in een sollicitatieprocedure goed concurreren met schoolverlaters met dezelfde opleiding.

Tabel 6.8

Werkervaring van de niet-participerenden, 2000

\begin{tabular}{lrrr}
\hline & $\begin{array}{r}\text { man } \\
\%\end{array}$ & $\begin{array}{r}\text { vrouw } \\
\%\end{array}$ & $\begin{array}{r}\text { totaal } \\
\%\end{array}$ \\
& & & 93 \\
Ooit werk gehad & 98 & 7 & 95 \\
Nooit werk gehad & 2 & 100 & 5 \\
Totaal & 100 & & 100
\end{tabular}

Bron: OSA-Arbeidsaanbodpanel (2000)

38. W. Smits (2001), Wie willen werkgevers? Personeelsselectie in de Zorg, de Metaalindustrie en de IT, ROA-W-2001/2, Maastricht. 


\section{Verklarende woordenlijst}

\section{Arbeidsmarktinstroom van schoolverlaters}

Het aanbod van nieuwe arbeidskrachten op de arbeidsmarkt, zoals deze is bepaald door de verwachte uitstroom van schoolverlaters uit het initiële dagonderwijs, de schoolverlaters van het deeltijdonderwijs, het niet-reguliere voltijdonderwijs en de beroepsgerichte volwasseneneducatie. Voor deze groep nieuwe arbeidskrachten wordt in dit rapport soms ook de alternatieve term 'nieuwkomers op de arbeidsmarkt' gebruikt.

\section{Arbeidsmarktkrapte}

Het begrip arbeidsmarktkrapte dat in deze rapportage gehanteerd wordt, is gedefinieerd als de verhouding tussen het aantal openstaande vacatures en het aantal niet-werkende werkzoekenden in bemiddelingsfase 1 per arbeidsmarktsegment. Wanneer de indicator voor de arbeidsmarktkrapte kleiner is dan één, is er sprake van een aanbodoverschot op het betreffende segment. Wanneer de indicator voor de arbeidsmarktkrapte groter is dan één, is er sprake van een tekort aan nietwerkende werkzoekenden in het betreffende segment. Dit tekort kan twee oorzaken hebben: wanneer het aanbod getalsmatig tekortschiet is er sprake van een kwantitatief probleem. De knelpuntsindicator (zie hier beneden) zal dan groter zijn dan één. Wanneer het probleem vooral gelegen is in het feit dat het percentage nietwerkende werkzoekenden in fase 1 laag is, is dit tekort vooral een kwalitatief aansluitingsprobleem dat zich zal manifesteren in een knelpuntsindicator kleiner dan één. Aangezien werkzoekenden niet naar bedrijfssector ingedeeld kunnen worden, kan deze maatstaf niet gebruikt worden om de arbeidsmarktkrapte naar bedrijfssector te berekenen. De arbeidsmarktkrapte naar bedrijfssector is daarom gedefinieerd als het gewogen gemiddelde van de arbeidsmarktkrapte naar beroepsgroep. De wegingsfactor is daarbij gebaseerd op het aandeel van de betreffende beroepsgroep in het totale aantal openstaande vacatures in die bedrijfssector. Hoe hoger de arbeidsmarktkrapte in een bedrijfssector, hoe groter de rekruteringsproblemen.

\section{Baanopeningen}

De baanopeningen representeren de totale vraag naar nieuwkomers op de arbeidsmarkt, zoals deze is bepaald door de werkgelegenheidsgroei (positieve uitbreidingsvraag) en de (netto) vervangingsvraag.

\section{Bedrijfssector}

Alle voorkomende bedrijven zijn ingedeeld in een aantal clusters. De in deze rapportage gepresenteerde informatie is - met uitzondering van de totale werkgelegenheid - verbijzonderd naar 13 bedrijfssectoren. Deze komen overeen met de door het CPB gehanteerde bedrijfssectorindeling. 


\section{Bemiddelingsfase}

Het begrip bemiddelingsfase dat in deze rapportage wordt gehanteerd, is gebaseerd op de indeling zoals die door Arbeidsvoorziening wordt gehanteerd. Een hogere bemiddelingsfase impliceert een grotere afstand tot de arbeidsmarkt:

- $\quad$ Fase 1: De werkzoekende voor wie arbeidsmarktinstrumenten beschikbaar zijn gericht op directe bemiddeling of terugkeer naar de arbeidsmarkt.

- $\quad$ Fase 2: De werkzoekende voor wie arbeidsmarktinstrumenten beschikbaar zijn gericht op een zodanige verbetering van de kans op werk, dat hij/zij binnen een tijdsbestek van maximaal een jaar als werkzoekende bemiddelbaar is op de arbeidsmarkt.

- $\quad$ Fase 3: De werkzoekende voor wie arbeidsmarktinstrumenten beschikbaar zijn gericht op een zodanige verbetering van de kans op werk, dat hij/zij binnen een tijdsbestek van meer dan een jaar als werkzoekende bemiddelbaar is op de arbeidsmarkt.

- Fase 4: De werkzoekende die tengevolge van zware persoonlijke werkbelemmeringen is aangewezen op hulp en zorg die gericht is op een zodanige verbetering van zijn/haar eigen positie dat eerst op termijn arbeidsmarktinstrumenten inzetbaar zijn gericht op de verbetering van zijn/haar kans op werk.

\section{Beroepsgroep, Beroepsklasse, Beroepssegment}

Alle voorkomende beroepen zijn ingedeeld in een aantal clusters. In deze rapportage en de bijbehorende Statistische Bijlage wordt afwisselend gebruik gemaakt van de indeling in 127 beroepsgroepen, 11 beroepssectoren en 43 beroepssegmenten.

\section{Bijscholing}

$\mathrm{Er}$ is sprake van bijscholing wanneer een scholingstraject de opleidingsachtergrond van een werkzoekende niet verandert.

\section{Conjunctuurgevoeligheid}

De conjunctuurgevoeligheid van de werkgelegenheid heeft betrekking op de mate waarin de werkgelegenheid voor mensen met een bepaalde opleidingsachtergrond gevoelig is voor veranderingen van de economische situatie. Deze indicator geeft daarmee de mate van werkzekerheid aan. De conjunctuurgevoeligheid wordt bepaald door de sectorale werkgelegenheidsfluctuaties in het verleden te relateren aan de mate waarin een opleidingstype momenteel in de verschillende bedrijfssectoren is vertegenwoordigd. Hierbij wordt rekening gehouden met het feit dat niet ieder opleidingstype even sterk meefluctueert met de werkgelegenheidsschommelingen van de bedrijfssector.

\section{Deeltijdarbeid}

Deeltijdarbeid betreft personen die hoogstens 32 uur maar minstens 12 uur per week werkzaam zijn.

\section{Eigen vakrichting}

Een indicatie van de mate waarin arbeidskrachten werkzaam zijn in een functie die niet goed aansluit bij de gevolge opleidingsrichting. De mate waarin schoolverlaters 
buiten de eigen vakrichting werkzaam zijn wordt in dit rapport vastgesteld door de schoolverlaters zelf te laten aangeven in hoeverre voor de door hen uitgeoefende functie de eigen of een verwante opleidingsrichting vereist is.

\section{Flexibel werk}

Van flexibel werk is sprake bij uitzendkrachten, oproepkrachten, invalkrachten, contracten zonder een vast aantal arbeidsuren en indien geen vast dienstverband is overeengekomen.

\section{Frictiewerkloosheid}

Frictiewerkloosheid is de min of meer onvermijdbare werkloosheid, die het gevolg is van het feit dat het bij het veranderen van werk, of het zoeken van een eerste baan, vaak enige tijd duurt voordat men na sollicitatie wordt aangenomen.

\section{Knelpuntsindicator}

Het begrip knelpuntsindicator dat in deze rapportage wordt gehanteerd is gedefinieerd als de verhouding tussen het aantal openstaande vacatures dat niet door niet-werkende werkzoekenden in bemiddelingsfase 1 vervuld kan worden en het aantal niet-werkende werkzoekenden in bemiddelingsfase 2 en 3 . Hoe hoger de knelpuntsindicator, hoe minder niet-werkende werkzoekenden met een grotere afstand tot de arbeidsmarkt er beschikbaar zijn voor de openstaande vacatures die niet door direct bemiddelbare werkzoekenden vervuld kunnen worden. Dit impliceert tevens dat een hoge knelpuntsindicator een werkzoekende in het betreffende segment de mogelijkheid biedt via bijscholing de kansen op een baan te vergroten. Wanneer het aantal niet-werkende werkzoekenden in fase 1 het aantal openstaande vacatures overtreft, is de knelpuntsindicator gelijk aan $0 . \mathrm{Er}$ is dan geen sprake van een tekort aan gekwalificeerd aanbod. Het aantal banen schiet juist tekort om alle direct inzetbare werkzoekenden aan werk te helpen.

\section{Langdurig werkzoekende}

Het begrip langdurig werkzoekende dat in deze rapportage wordt gehanteerd, is gedefinieerd als een werkzoekende die langer dan een jaar ingeschreven is bij Arbeidsvoorziening. Opgemerkt dient te worden dat dit niet noodzakelijkerwijs impliceert dat de betreffende werkzoekende tijdens de periode niet gewerkt heeft.

\section{Langdurig openstaande vacature}

Het begrip langdurig openstaande vacature dat in deze rapportage wordt gehanteerd, is gedefinieerd als een vacature die langer dan drie maanden openstaat.

\section{Omscholing}

Er is sprake van omscholing wanneer het scholingstraject de opleidingsachtergrond van een werkzoekende verandert. Omscholing kan zowel niveauverhogend als richtingveranderend van aard zijn. 


\section{Onderbenutting}

Onderbenutting is een indicatie van de mate waarin arbeidskrachten werkzaam zijn op een functieniveau dat lager is dan hun opleidingsniveau. De onderbenutting van schoolverlaters wordt in dit rapport vastgesteld door de schoolverlaters zelf te laten aangeven welk opleidingsniveau vereist is voor de door hen uitgeoefende functie.

\section{Opleidingssector, Opleidingstype}

Alle voorkomende opleidingen zijn samengevoegd tot een aantal clusters. In de prognosemethodiek en in de bij dit rapport verschenen Statistische Bijlage wordt voornamelijk uitgegaan van 113 opleidingstypen. In het rapport wordt in de meeste gevallen echter een indeling naar 21 opleidingssectoren gehanteerd.

\section{Potentiële beroepsbevolking}

De potentiële beroepsbevolking omvat de werkenden, de werklozen en de nietparticiperenden. ledereen die tussen de 15 en de 64 jaar oud is en geen voltijdopleiding volgt, wordt tot de potentiële beroepsbevolking gerekend. Als men meer dan 12 uur per week werkt, wordt men tot de werkzame beroepsbevolking gerekend. Werkt men niet of minder dan 12 uur, maar wil men wel minstens 12 uur per week betaalde arbeid verrichten, dan behoort men tot de werkloze beroepsbevolking. Werkt men niet of minder dan 12 uur, en is men niet op zoek naar betaalde arbeid voor minstens 12 uur per week, dan behoort men tot de nietparticiperende beroepsbevolking (de zgn. 'stille reserve').

\section{Toekomstig arbeidsmarktperspectief}

Het toekomstig arbeidsmarktperspectief geeft de verhouding tussen aanbod en vraag in de prognoseperiode voor een opleidingstype weer. Als het arbeidsmarktperspectief slecht is, betekent dit dat er in het (de) komende ja(a)r(en) veel meer aanbod van nieuwkomers is dan er baanopeningen zijn. Hierdoor zal de arbeidsmarktpositie gaan verslechteren. Deze verslechtering kan een hogere werkloosheid betekenen, maar door aanpassingsprocessen op de arbeidsmarkt kan dit ook leiden tot het moeten aanvaarden van banen op een lager niveau, een lagere beloning en meer tijdelijke contracten. Omgekeerd zal een goed perspectief tot een grotere kans op werk, maar ook tot een verbeterde positie op andere punten leiden. Het toekomstig arbeidsmarktperspectief per opleidingstype wordt bepaald door middel van de Indicator Toekomstige Arbeidsmarktsituatie (ITA), die is gedefinieerd als de verhouding tussen enerzijds de verwachte instroom van schoolverlaters en het aantal direct bemiddelbare werkzoekenden en anderzijds de verwachte baanopeningen. Naarmate de waarde van de indicator hoger is, is het perspectief slechter. Analoog geeft de Indicator Toekomstige Arbeidsmarktsituatie naar Beroep (ITAB) het arbeidsmarktperspectief naar beroepsgroep weer. Merk overigens op dat een hogere ITA of ITAB een slechtere (toekomstige) arbeidsmarktsituatie impliceert, terwijl een hogere arbeidsmarktkrapte een indicatie is voor een betere (huidige) arbeidsmarktpositie van een opleidingstype.

\section{Toekomstige knelpunten in de Personeelsvoorziening}

Als de toekomstige vraag naar werkenden met een bepaalde opleidingsachtergrond groter is dan het aanbod, kunnen knelpunten in de personeelsvoorziening verwacht 
worden. Vergelijkbaar met de Indicator Toekomstige Arbeidsmarktsituatie (ITA, zie hierboven) geeft de Indicator Toekomstige Knelpunten in de Personeelsvoorziening (ITKP) deze vraag-aanbod-spanning aan. Het verschil met de ITA is dat bij de ITKP de uitstroom van werkenden als gevolg van een krimpende werkgelegenheid is meegerekend in de vraag, omdat verwacht mag worden dat bij knelpunten in de personeelsvoorziening deze (gedwongen) uitstroom kan worden afgeremd of elders werk zou kunnen vinden. Naarmate de waarde van de indicator lager is, zijn de verwachte knelpunten groter. Analoog geeft de Indicator Toekomstige Knelpunten in de personeelsvoorziening naar Beroep (ITKB) de knelpunten naar beroepsgroep weer.

\section{Toekomstige Knelpunten in de personeelsvoorziening naar Beroep}

Voor het vaststellen van de verwachte knelpunten in de personeelsvoorziening naar beroep gebruiken we de Indicator Toekomstige Knelpunten in de personeelsvoorziening naar Beroep (ITKB). Deze indicator geeft aan in welke mate werkgevers problemen ondervinden bij het aantrekken van geschikt personeel. Naarmate de waarde van de ITKB lager is, zijn er meer knelpunten te verwachten. Wanneer het aanbod kleiner is dan de vraag, dan is de ITKB kleiner dan 1,00. De knelpunten in de personeelsvoorziening worden dan als groot getypeerd. Als de waarde van de indicator zelfs kleiner is dan 0,85 dan wordt gesproken van zeer grote knelpunten. Wanneer de ITKB daarentegen tussen 1,00 en 1,05 ligt, dan wordt gesproken van enige knelpunten. Bij een hogere waarde van de ITKB is sprake van vrijwel geen knelpunten, en mocht de ITKB zelfs groter zijn dan 1,15, dan is er sprake van geen knelpunten in de personeelsvoorziening.

\section{Uitbreidingsvraag}

De uitbreidingsvraag is de vraag naar nieuwe arbeidskrachten die ontstaat door groei van de werkgelegenheid. Als er sprake is van een werkgelegenheidsdaling, is de uitbreidingsvraag negatief.

\section{Uitwijkmogelijkheden}

Dit is de mate waarin arbeidskrachten met een bepaalde opleidingsachtergrond terecht kunnen komen in andere beroepsgroepen op een aansluitend of hoger functieniveau. Deze maatstaf geeft daarmee aan in hoeverre arbeidskrachten afhankelijk zijn van de arbeidsmarktsituatie in een bepaald beroep. De uitwijkmogelijkheden worden bepaald met behulp van een spreidingsindex. Deze index geeft een indicatie van het aantal beroepsgroepen waarnaar men kan uitwijken.

\section{Vacature}

Het begrip vacature is in deze rapportage gebaseerd op de door het CBS gehanteerde definitie van een openstaande vacature, zijnde een arbeidsplaats waarvoor personeel wordt gezocht dat onmiddellijk of zo spoedig mogelijk geplaatst kan worden. 


\section{Vacaturegraad}

De vacaturegraad is het aantal openstaande vacatures per 1.000 werkenden in een bedrijfs-, beroeps- of opleidingssector.

\section{Vervangingsvraag}

Vervangingsvraag is de vraag naar nieuwe arbeidskrachten die ontstaat doordat de arbeidsplaatsen van werkenden die met pensioen gaan, arbeidsongeschikt worden of zich (tijdelijk) terugtrekken van de arbeidsmarkt, opnieuw moeten worden opgevuld. De vervangingsvraag per beroepsgroep kan bovendien ontstaan door de beroepsmobiliteit. Verder kan een onderscheid worden gemaakt tussen de netto en de bruto vervangingsvraag. De netto vervangingsvraag heeft alleen betrekking op de vervangingsbehoefte voor zover deze opgevuld zou moeten worden door schoolverlaters die op de arbeidsmarkt instromen. De bruto vervangingsvraag is de totale uitstroom van werkenden die vervangen moeten worden. De bruto vervangingsvraag omvat dus ook de vervangingsvraag die zou kunnen worden opgevuld door herintreders en baanwisselaars. In het huidige rapport wordt alleen de netto vervangingsvraag gebruikt en gepresenteerd.

\section{Vraagoverschot}

Het begrip vraagoverschot wordt in dit rapport op twee manieren gebruikt. In enge zin (in hoofdstuk 1) betreft het vraagoverschot het verschil tussen het aantal baanopeningen en het verwachte aanbod van schoolverlaters. In ruime zin (omdat immers ook bij- en omscholing van niet-werkende werkzoekenden een instrument kan zijn om op knelpunten te anticiperen) is het vraagoverschot (in hoofdstuk 4) gedefinieerd als het verschil tussen de som van de openstaande vacatures en de verwachte baanopeningen enerzijds en de direct-inzetbare werkzoekenden - de schoolverlaters en de niet-werkende werkzoekenden in fase 1 - anderzijds.

\section{Werkloosheid onder schoolverlaters}

De werkloosheid onder schoolverlaters is het aantal werklozen uitgedrukt als percentage van het aantal schoolverlaters met een bepaalde opleidingsachtergrond.

\section{Werkzoekende}

Het begrip werkzoekende is in deze rapportage gedefinieerd als de bij Arbeidsvoorziening ingeschreven niet-werkende werkzoekenden, inclusief de categorie "geen beroep op dienstverlening". 